Final Report

FHWA/IN/JTRP-2002/11

\title{
AN EVALUATION OF INNOVATIVE TRANSPORTATION FINANCING TECHNIQUES FOR INDIANA
}

\author{
By \\ Kristine Drike \\ Graduate Research Assistant \\ School of Civil Engineering \\ A. Vincent Genetti \\ Graduate Research Assistant \\ Krannert School of Management \\ and \\ Kumares C. Sinha \\ Olson Distinguished Professor of Civil Engineering \\ Joint Transportation Research Program \\ Project No. C-36-73R \\ File No.3-4-18 \\ SPR-2467 \\ In Cooperation with the \\ Indiana Department of Transportation \\ and the Federal Highway Administration
}

The contents of this report reflect the views of the authors, who are responsible for the facts and the accuracy of the data presented herein. The contents do not necessarily reflect the official views or policies of the Indiana Department of Transportation or the Federal Highway Administration. This report does not constitute a standard, specification or regulation.

Purdue University

West Lafayette, Indiana 47907

August 2002 


\section{ACKNOWLEDGEMENTS}

The authors acknowledge the assistance and guidance of the following Study Advisory Committee members: Rick Whitney, Deputy Commissioner and Chief Financial Officer, Gary Eaton, Chief of Budget and Fiscal Management Division, and Samy Noureldin of the Research Division, Indiana Department of Transportation (INDOT); and Jay DuMontelle of the Indiana Division of Federal Highway Administration. In addition, the authors are grateful to Chris Kubik of the INDOT Budget and Fiscal Management Division and Mike Hazeltine of the INDOT Contracts and Construction Division for their most helpful assistance in collecting information on various projects analyzed in the study. 


\section{TECHNICAL Summary}

INDOT Research

Technology Transfer and Project Implementation Information

TRB Subject Code: 14-5 Financial Sources

Publication No.: FHWA/IN/JTRP-2002/11, SPR-2467

August 2002

Final Report

\section{AN EVALUATION OF INNOVATIVE FINANCING TECHNIQUES FOR INDIANA}

\section{Introduction}

Annual federal apportionments and Indiana state revenues are not sufficient to maintain and improve state highways so innovative approaches in transportation project financing should be sought. There are several available innovative financing techniques associated with the use of federal funds. Although they do not provide new sources of revenue and cannot create enough funds for all identified projects, these techniques provide flexibility in the use of available funds that can expedite the implementation of individual projects. In this study an evaluation of the major innovative financing techniques associated with federal funds and their applicability for transportation projects in Indiana was performed. The legal, financial, and operational issues of various alternatives were examined and the economic impacts were investigated in terms of user benefits and debt service of the transportation agency. Possible revenue sources for debt service payment also were identified, and from a legal perspective, factors such as eligibility, authorization parties, and administration of financing assistance were addressed. Innovative financing techniques considered in the study include:

- $\quad$ the Test and Evaluation Project 045 (TE-045 program),

- Grant Anticipation Revenue Vehicle Bonds (GARVEE)

- the Transportation Infrastructure Finance and Innovation Act (TIFIA), and

- $\quad$ the State Infrastructure Bank (SIB).

The following four INDOT projects were used as case studies in the analysis:

- US 31 Corridor Improvement Project,

- SR 641 Terre Haute Bypass Project,

- I-69 Evansville to Indianapolis Project, and

- Louisville-Southern Indiana Ohio River Bridges Project.

\section{Findings}

Innovative financing techniques can be adapted to leverage the use of available federal and state funding, and different techniques can be chosen according to project size, term, geographical location, and other characteristics. Some techniques (GARVEE bonds) are applicable to most project types, while others (TIFIA) are restricted in their use.

- The TE-045 program provides a wide spectrum of innovative financing techniques associated with federal funds. TE-045 does not provide financial assistance; rather it fosters the identification and implementation

of new, flexible strategies to overcome the fiscal, institutional, and administrative obstacles in financing projects.

- A large share of the project cost could be financed through GARVEE bonds, which is appropriate financing when the additional public benefits resulting from early project completion exceed the financing costs. Economic analysis concludes that the debt service for such a bond issuance could likely be met through existing state sources for debt service payments in Indiana. 
- $\quad$ The TIFIA program is limited in its use, but it can be a helpful tool to fund projects possessing their own non-federal repayment streams. For implementation in Indiana, the feasibility of using such sources as tax increment financing or tolls can be considered to cover costs incurred in using TIFIA assistance.

- Small, short-term projects could be financed through loans provided by a State Infrastructure Bank (SIB). Since Indiana SIB capital is very limited, this technique is more applicable to projects at the local level.
Most of the innovative financing techniques discussed in the study involve borrowing money. It is preferable to use GARVEE or TIFIA programs rather than borrow money from a regular lending institution, as interest rates under these programs tend to be lower and repayment conditions more flexible. The interest rate, discount rate, and term of borrowing are the critical factors that need to be carefully considered to evaluate the impact of innovative financing techniques on economic viability of a project.

\section{Implementation}

The following recommendations are suggested for possible further investigation and implementation.

- The financial market conditions should be carefully examined before applying financing techniques that involve borrowing. Particular attention should be paid to such factors as interest rate, discount rate, and consistent flow of revenues.

- It is recommended that documentation defining the objectives of the Indiana SIB be prepared and should include the scope of work and eligibility requirements for financial assistance. Such documentation would serve as a basis to make Indiana SIB assistance more accessible to public and private entities for transportation project financing.

- Comparison between the impacts of different financing techniques can be made in greater detail than what was possible in the present study. For such a comparison, it will be necessary to have detailed information on specific projects, including the economic analysis data specific to the requirements of various financing techniques. Such an analysis can suggest possible optimal financial formulas based on economic and financial measures as performance indicators.

- The study provides a framework for the evaluation of the use of innovative financing techniques

- The study provides a framework for the evaluation of the use of innovative financing techniques described in this report. With detailed project specific data, INDOT Budget and Fiscal Management Division can conduct a project-by-project analysis to find the optimal solution for individual project

\section{Contacts}

For more information:

Prof. Kumares C. Sinha

Principal Investigator

School of Civil Engineering

Purdue University

West Lafayette IN 47907

Phone: (765) 494-2211

Fax: (765) 496-1105
Indiana Department of Transportation

Division of Research

1205 Montgomery Street,P.O. Box 2279

West Lafayette, IN 47906

Phone: (765) 463-1521

Fax: (765) 497-1665

Purdue University

Joint Transportation Research Program

School of Civil Engineering

West Lafayette, IN 47907-1284

Phone: (765) 494-9310

Fax: (765) 496-1105 
TECHNICAL REPORT STANDARD TITLE PAGE

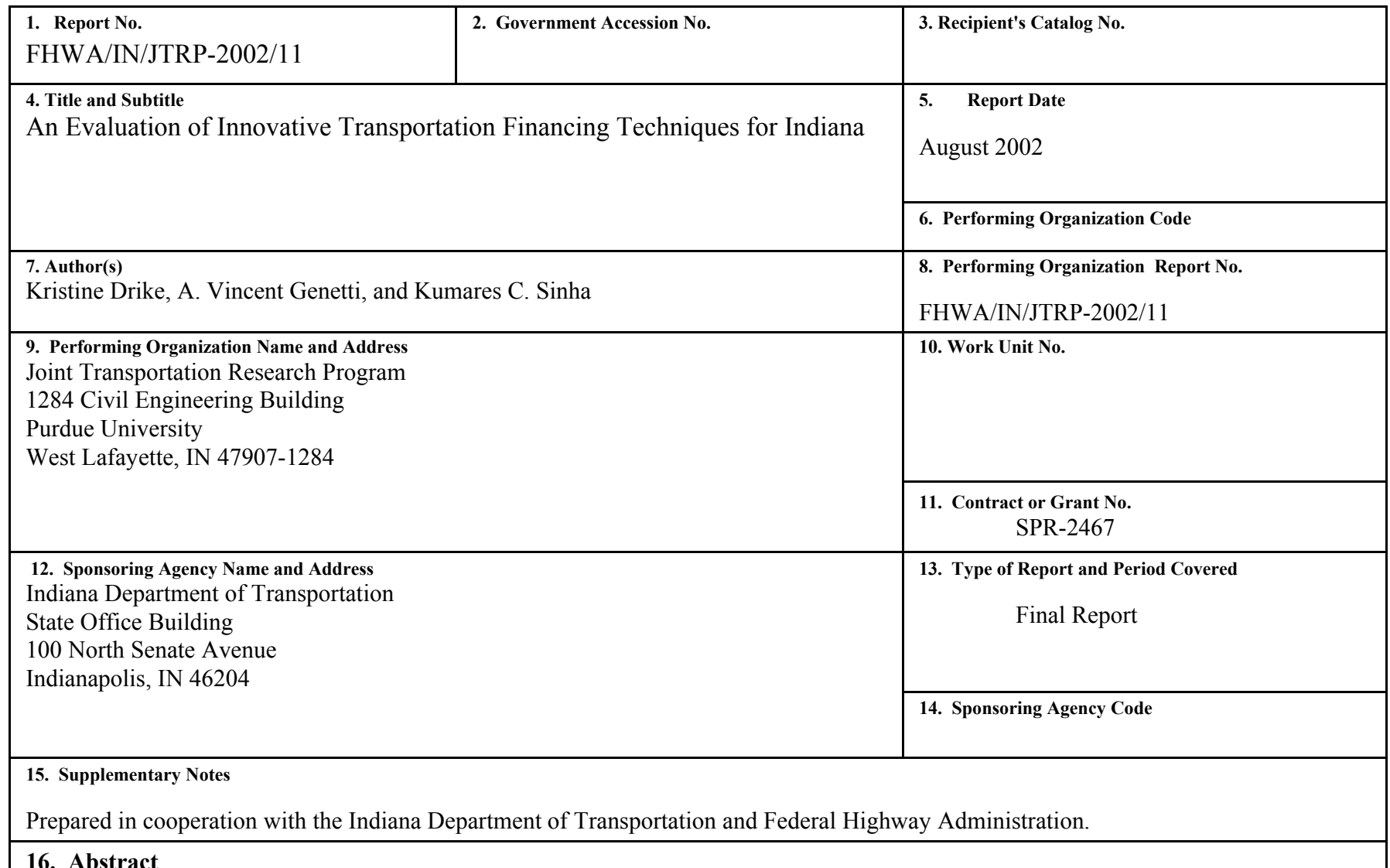

Innovative financing techniques can complement current methods of financing highway projects in Indiana. Annual federal apportionments and Indiana state revenues are not sufficient to maintain and improve state highways, so innovative approaches in transportation project financing should be sought. There are several available innovative financing techniques associated with the use of federal funds. Although, they do not provide new sources of revenue and cannot create enough funds for all identified projects, they provide flexibility in the use of available funds that can expedite the implementation of individual projects.

The main objective of this study was to evaluate the major innovative financing techniques associated with federal funds, and their applicability for transportation projects in Indiana. The legal, financial, and operational issues of various alternatives were examined, and the economic impacts were investigated in terms of user benefits and debt service of the transportation agency. Possible revenue sources for debt service payment also were identified, and from a legal perspective, factors such as eligibility, authorization parties, and administration of financing assistance were addressed. Innovative financing techniques considered in the study include: the Test and Evaluation Project 045 (TE-045 program), Grant Anticipation Revenue Vehicle Bonds (GARVEE), the Transportation Infrastructure Finance and Innovation Act (TIFIA), and the State Infrastructure Bank (SIB). Four actual INDOT projects were used as case studies in the analysis.

The study provides a framework for the evaluation of the use of innovative financing techniques described in this report. With detailed project specific data project-by-project analysis can be done to find the optimal solution for individual project financing.

\section{Key Words}

Highway financing, innovative financing, federal funds, Indiana State Highway Network

18. Distribution Statement

No restrictions. This document is available to the public through the National Technical Information Service, Springfield, VA 22161

\begin{tabular}{|c|c|c|c|}
\hline $\begin{array}{c}\text { 19. Security Classif. (of this report) } \\
\text { Unclassified }\end{array}$ & 20. Security Classif. (of this page) & 21. No. of Pages & 22. Price \\
\hline
\end{tabular}




\section{TABLE OF CONTENTS}

LIST OF TABLES.

LIST OF FIGURES

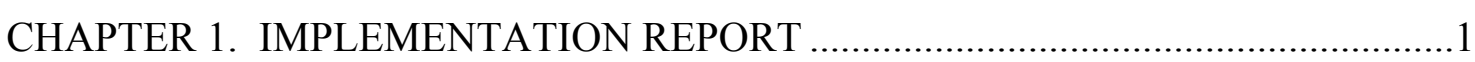

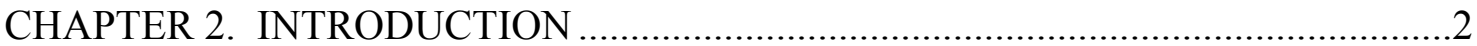

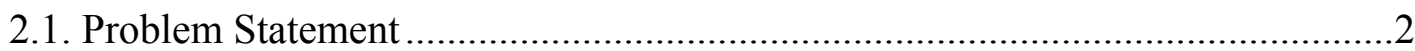

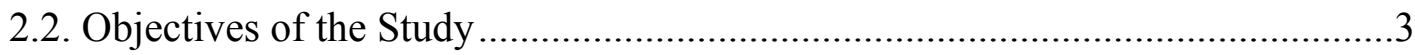

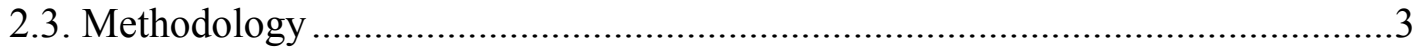

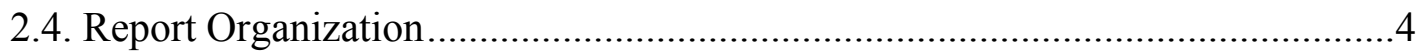

CHAPTER 3. BACKGROUND INFORMATION …............................................5

3.1. Current Transportation Financing Mechanism ................................................5

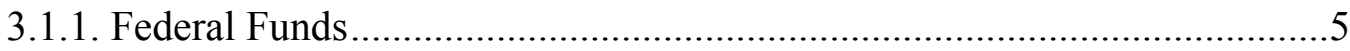

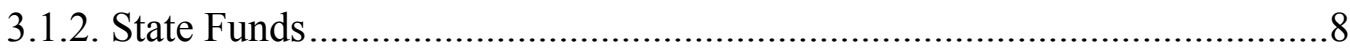

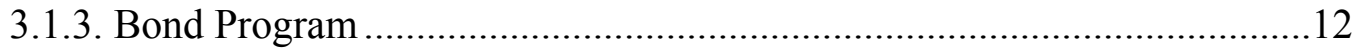

3.2. Need for Innovative Financing .............................................................. 15

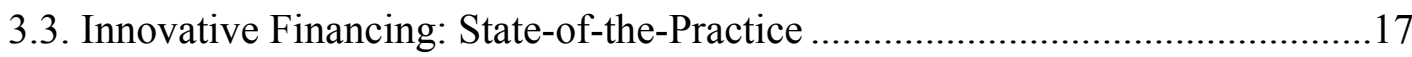

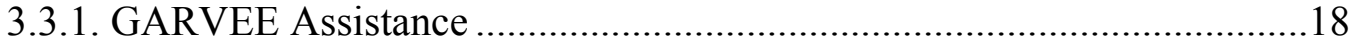

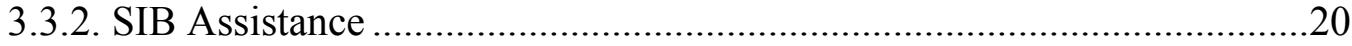

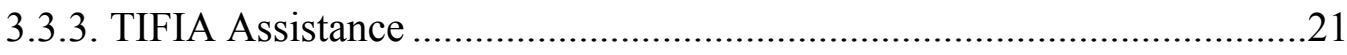

CHAPTER 4. EVALUATION OF INNOVATIVE FINANCING TECHNIQUES .....23

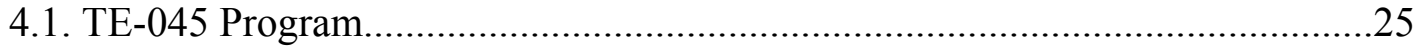

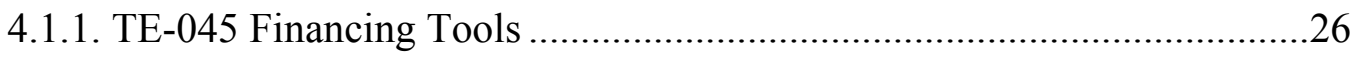

4.1.2. The States' Response to the Program .................................................27

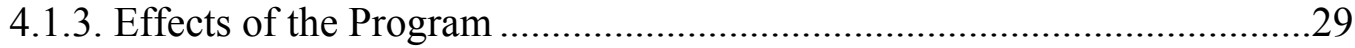

4.2. Grant Anticipation Revenue Vehicle (GARVEE) Bonds ...............................30

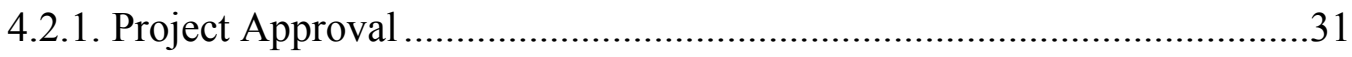

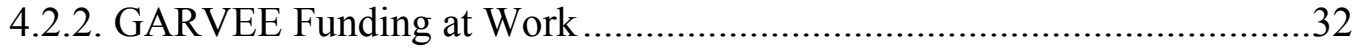

4.2.3. GARVEE Bonds in the Financial Market.............................................33

4.2.4. Pros and Cons of GARVEE Bonds ......................................................34 
4.2.5. Applicability of GARVEE Program in Indiana .....................................36

4.2.5.1. U.S. 31 Corridor Improvement Project ...........................................36

4.2.5.2. SR 641 (Terre Haute Bypass) .......................................................49

4.2.5.3. I-69 (Evansville-to-Indianapolis).............................................63

4.2.5.4. Louisville-Southern Indiana Ohio River Bridges Project................76

4.3. Transportation Infrastructure Finance and Innovation Act............................89

4.3.1. Eligible Costs and Selection of Projects .............................................90

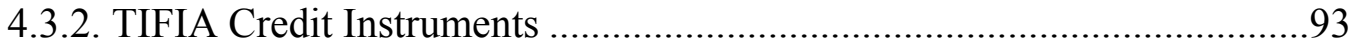

4.3.3. TIFIA Program Available Funding ...................................................97

4.3.4. Possible TIFIA Credit Assistance for INDOT Projects ...........................98

4.3.4.1. I-69 (Evansville-to-Indianapolis)..............................................99

4.3.4.2. SR 641 (Terre Haute Bypass) .....................................................106

4.3.4.3. Louisville-Southern Indiana Ohio River Bridges Project..............107

4.3.4.4. U.S. 31 Corridor Improvement Project .......................................114

4.3.5. Pros and Cons of TIFIA Program ..........................................................120

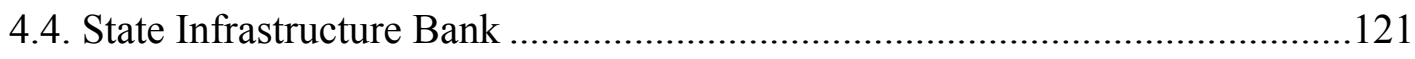

4.4.1. SIB Capitalization and Leveraging ...................................................123

4.4.2. Types of SIB Financial Assistance ...................................................124

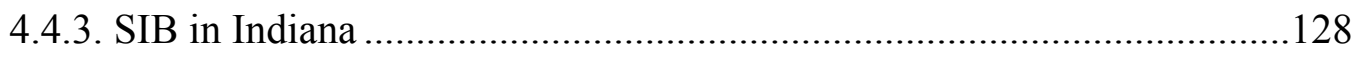

4.5. Comparison Between Available Innovative Financing Techniques ................129

CHAPTER 5. CONCLUSIONS AND RECOMMENDATIONS ............................132

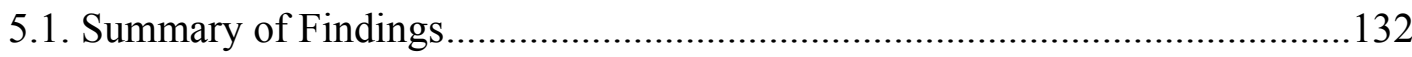

5.2. Recommendations for Further Investigation and Implementation .................133

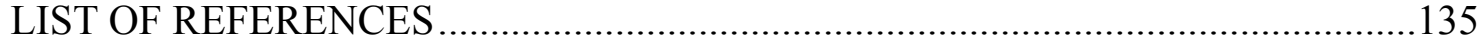

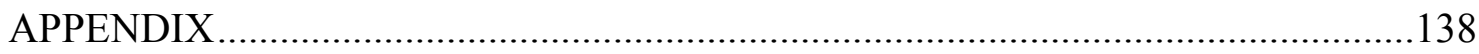

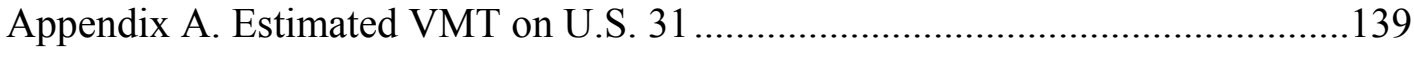

Appendix B. State Infrastructure Bank Loan Agreements by State ......................140 


\section{LIST OF TABLES}

3.1 User Fee Structure....................................................................................6

3.2 Indiana State Transportation Revenues in FY 2000 ..............................................

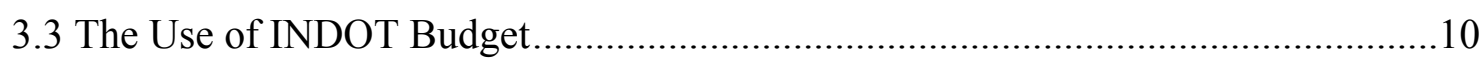

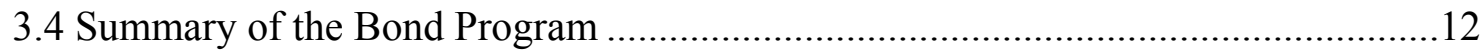

3.5 Debt Service Schedule for 2001-2006 ...............................................................

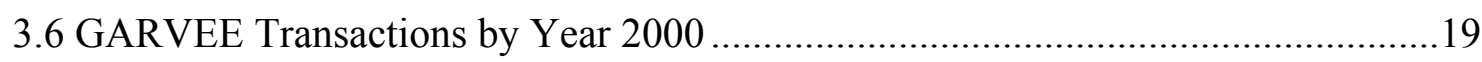

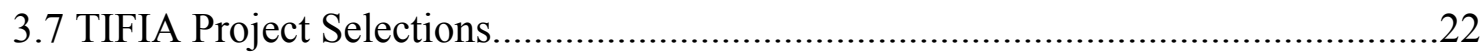

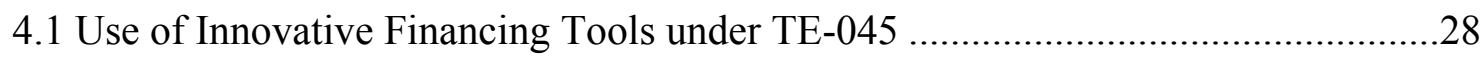

4.2 U.S. 31 Annual Debt Service for $\$ 1200$ Million Bond Issuance................................39

4.3 U.S. 31 Annual Debt Service for $\$ 600$ Million Bond Issuance...................................40

4.4 SR 641 Annual Debt Service for \$79 Million Bond Issuance ....................................53

4.5 I-69 Annual Debt Service for \$1.2 Billion Bond Issuance ........................................66

4.6 ORBP Annual Debt Service for INDOT’s Portion ( $\$ 720$ Million ) of

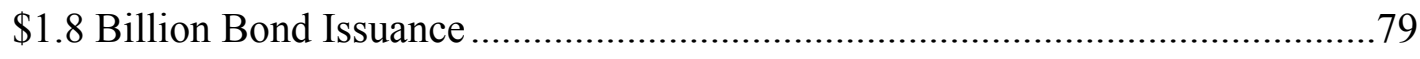

4.7 I-69 Revenue from Property Tax in Study Area in 2000 ……………...................102

4.8 I-69 CEDIT Rates and Revenues by County, 2000 …........................................105

4.9 I-69 Motor Vehicle Excise Revenue by County, 1998 ………………………......106

4.10 ORBP Revenue from Property Tax in Study Area, Fiscal Year 2000 ...................110

4.11 U.S. 31 Revenue from Property Tax in Study Area, Fiscal Year 2000 .................116

4.12 U.S. 31 CEDIT Rates and Revenues by County, Fiscal Year 2000 .....................119

4.13 U.S. 31 Motor Vehicle Excise Revenue by County, Fiscal Year 2000 ................119

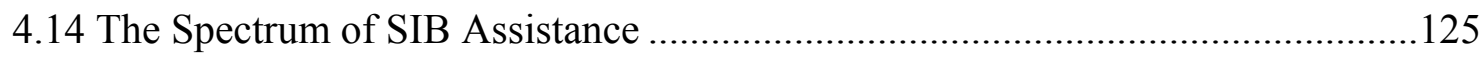

4.15 Loan Issuance Conditions in Different States.....................................................126

4.16 A Comparison of Innovative Financing Techniques ............................................131 


\section{LIST OF FIGURES}

Page

3.1 The Structure of the Highway Trust Fund Revenues in 2000 ..................................

3.2 Revenue Sources for Transportation in Indiana in Fiscal Year 2000 ........................9

3.3 Funds for Capital Improvements within the INDOT Construction Budget...............16

4.1 Federal Assistance for Transportation Infrastructure ………………………….......24

4.2 Procedure for Receiving Federal-Aid Reimbursement Using GARVEE Bonds......31

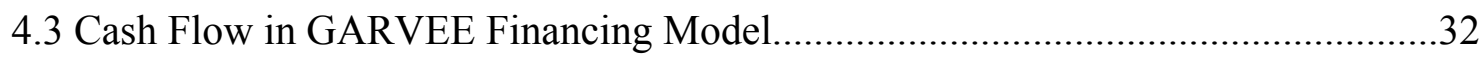

4.4 U.S. 31 Annual Debt Service in Percents of Federal Apportionment in 2005 for Different Maturity Bonds ...............................................................................41

4.5 U.S. 31 NPV of GARVEE Financing Transaction (Discount Rate 7\%) ..................42

4.6 U.S. 31 NPV of GARVEE Financing Transaction (Discount Rate 3\%) ..................43

4.7 U.S. 31 NPV with Respect to Different Values of Interest Rate, Maturity and Amount Issued in GARVEE Bonds....................................................................4

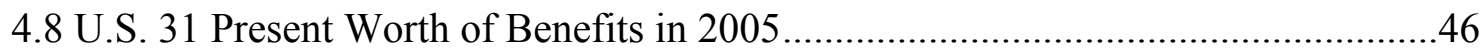

4.9 U.S. 31 Present Worth of Benefits and Total Debt Service in 2005 .........................47

4.10 U.S. 31 Discounted Benefits and PW of Debt Service in 2005 with Incorporated

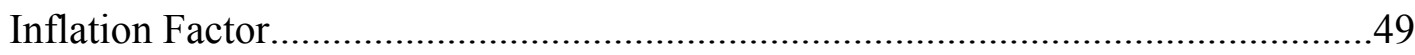

4.11 SR 641 Annual Debt Service in Percents of Federal Apportionment in 2003

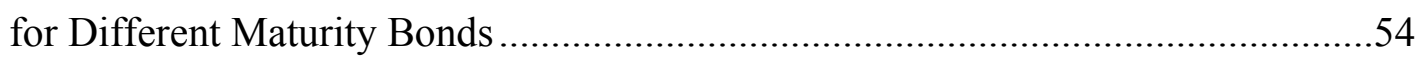

4.12 SR 641 NPV of GARVEE Financing Transaction (Discount Rate 8\%) ................55

4.13 SR 641 NPV of GARVEE Financing Transaction (100\% Project Financing).......56

4.14 SR 641 NPV with Respect to Different Values of Interest Rate, Maturity and

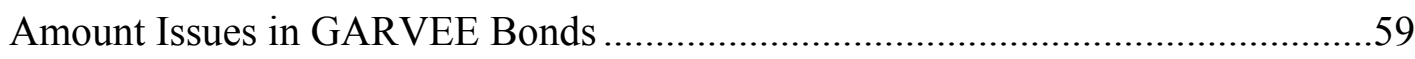

4.15 SR 641 NPV with Respect to Different Values of Maturity and

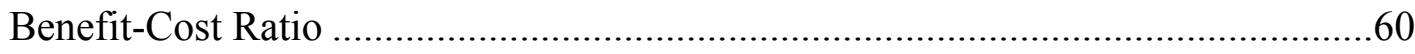

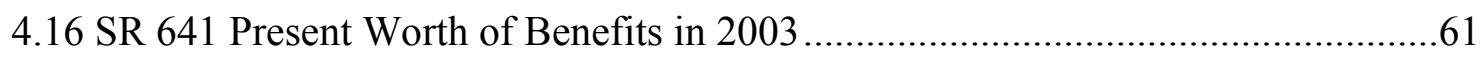

4.17 SR 641 Present Worth of Benefits and Total Debt Service in 2003 ......................62

4.18 SR 641 Discounted Benefit and PW of Debt Service in 2003 with Incorporated Inflation Factor. 
4.19 I-69 Annual Debt Service in Percents of Federal Apportionment in 2005

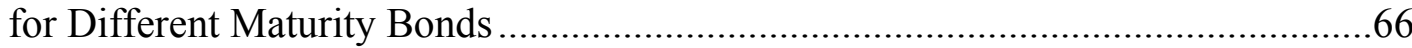

4.20 I-69 NPV of GARVEE Financing Transaction (Discount Rate 7\%)......................68

4.21 I-69 NPV of GARVEE Financing Transaction (100\% Project Financing) ............69

4.22 I-69 NPV with Respect to Different Values of Interest Rate, Maturity and

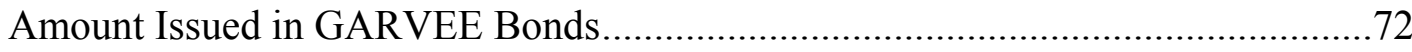

4.23 I-69 NPV with Respect to Different Values of Maturity and

Benefit-Cost Ratio ……..........................................................................................73

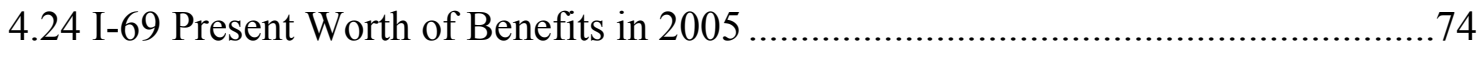

4.25 I-69 Present Worth of Benefits and Total Debt Service in 2005 ...........................75

4.26 I-69 Discounted Benefits and PW of Debt Service in 2005 with Incorporated

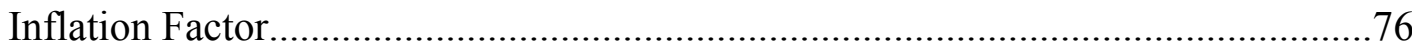

4.27 ORBP Annual Debt Service in Percents of Federal Apportionment in 2000

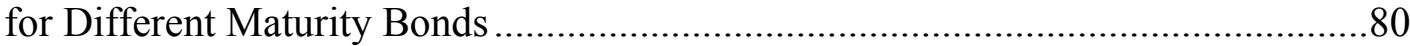

4.28 ORBP NPV of GARVEE Financing Transaction (Discount Rate 7\%) ..................81

4.29 ORBP NPV of GARVEE Financing Transaction (100\% Project Financing) .........82

4.30 ORBP NPV with Respect to Different Values of Interest Rate, Maturity and

Amount Issued in GARVEE Bonds.

4.31 ORBP NPV with Respect to Different Values of Maturity and

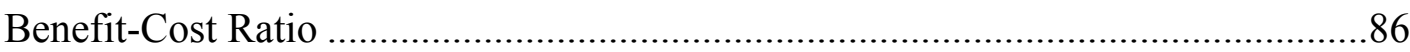

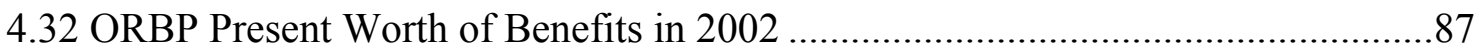

4.33 ORBP Present Worth of Benefits and Total Debt Service in 2002 .......................88

4.34 ORBP Discounted Benefits and PW of Debt Service in 2002 with Incorporated

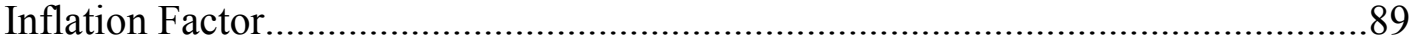

4.35 Application and Review Process for TIFIA Credit Assistance …….....................92

4.36 Assigned Weights for Selection Criteria (percentage amounts) ..............................93

4.37 Potential Forms of Federal Credit Assistance Over a Project's Life ......................95

4.38 Credit Amount and Budget Authority Limitations ...................................................97

4.39 I-69 Annual Payments for Federal Loan with Different Terms and

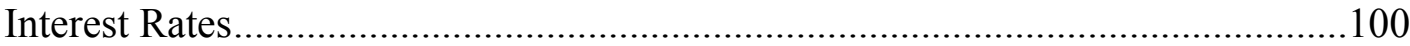

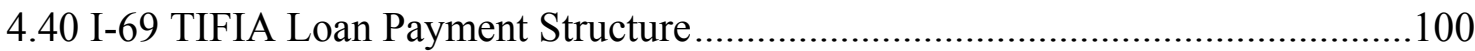

4.41 I-69 Estimated Average Toll Rate with Respect to Increase in VMT in 2008 .....104 
4.42 ORBP Annual Payments for Federal Loan with Different Terms and

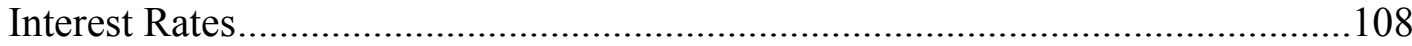

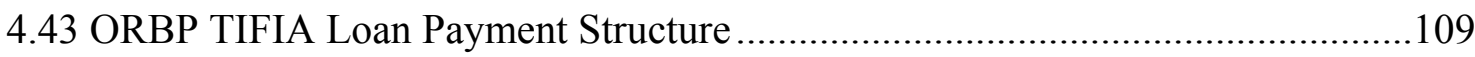

4.44 ORBP Estimated Toll Rate with Respect to Estimated \# of Daily Bridge

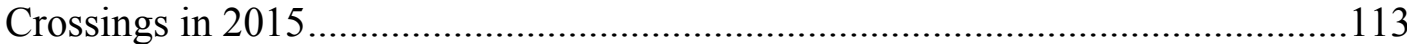

4.45 U.S. 31 Annual Payments for Federal Loan with Different Terms and

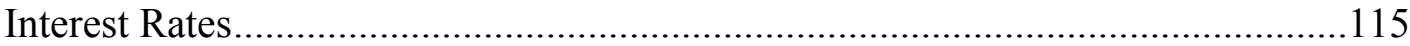

4.46 U.S. 31 TIFIA Loan Payment Structure …………………………………....115

4.47 U.S. 31 Estimated Average Toll Rate with Respect to Varying VMT .................118

4.48 Basic Structure of a State Infrastructure Bank ......................................................122

4.49 Outlay Rate for Federal-aid Highway Programs ..................................................123 


\section{CHAPTER 1. IMPLEMENTATION REPORT}

The Indiana highway system is mainly supported by federal and state fuel taxes and other related fees. It is not easy to change practices that have served well for many years, but the traditional "pay-as-you-go" financing approach is increasingly unable to satisfy the accelerating needs for improvement in the state highway system. There are several innovative financing tools provided by federal government that the states can adopt in order to expand the use of existing federal funds. This study was intended to evaluate the available tools and their applicability for Indiana.

The alternative techniques discussed here are not the only ones available, but they do represent the options most likely to yield a significant increase in funding and accelerating the execution of projects in Indiana. Innovative financing techniques can be adapted to leverage the use of available federal and state funding and accelerate the execution of a project. Different techniques can be chosen according to project size, term, geographical location, and other characteristics. Some techniques, e.g., GARVEE bonds, are applicable to most project types, while others, e.g., TIFIA, are restricted in their use.

Most of the innovative financing techniques discussed in the study involve borrowing money. However, interest rates under these programs tend to be lower and repayment conditions more flexible than what are offered by regular lending institutions. The interest rate, discount rate, and term of borrowing are the critical factors that need to be carefully considered to evaluate the impact of innovative financing techniques on economic viability of a project.

The study provides a framework for the evaluation of the use of innovative financing techniques described in this report. With detailed project specific data projectby-project analysis can be done to find the optimal solution for individual project financing. The Budget and Fiscal Management Division is the expected unit within INDOT to follow-up and implement the findings of the study. 


\section{CHAPTER 2. INTRODUCTION}

\subsection{Problem Statement}

Over the past 40 years, highway infrastructure financing has been built predominantly on a pay-as-you-go basis. The Federal Aid Highway Act of 1956 created the Highway Trust Fund, providing a stable funding source for the highway system in the U.S. Since the early 1970s, the Trust Fund approach has encountered a series of structural problems that necessitate new means of financing highway maintenance and improvement. As the cost of identified infrastructure projects began to outpace traditional funding sources in the 1980's, state and local governments began to experiment with alternative ways to finance transportation infrastructure. Passage of the Intermodal Surface Transportation Efficiency Act of 1991 (ISTEA) was the first federal legislation offering options to state and local governments to finance highway infrastructure projects, and continued with the National Highway System Designation Act of 1995, the Transportation Infrastructure Finance and Innovation Act of 1998 (TIFIA), and the Transportation Equity Act for the 21st Century of 1998 (TEA-21) [Dornan, 2000].

Traditional highway funding methods provided authority to the Federal Highway Administration (FHWA) to dictate the terms and conditions for administering the funds. In the last decade, however, the increasing involvement of state and local governments, as well as the private sector, in financing transportation projects has led to a gradual transfer of administrative authority to these parties.

INDOT has identified and prioritized specific highway projects in its 2000-2025 Long Range Plan. Many of these projects have been postponed due to high costs and limited funds. Annual federal apportionments and Indiana state revenues are not sufficient to implement these highway projects. Postponing improvement of the highway system can have substantial adverse impact as road users incur higher vehicle operating costs, safety hazards, and time delays. Current transportation funding sources for INDOT 
are not sufficient to advance many large-scale projects that would provide significant highway improvements; therefore, innovative approaches to transportation project financing should be considered to complement available highway financing. Although, innovative financing techniques associated with the use of federal funds do not provide new sources of revenue and cannot create enough funds for all identified projects, they provide an opportunity to use the existing federal and state transportation financing more efficiently and thus to expedite the completion of individual projects. These techniques could make timely execution of more projects and produce widespread benefits that could not otherwise be possible.

\subsection{Objectives of the Study}

The present study primarily focuses on major innovative financing techniques associated with federal funding: the Test and Evaluation Project 045 (TE-045 Program), Grant Anticipation Revenue Vehicle Bonds (GARVEE), the Transportation Infrastructure Finance and Innovation Act (TIFIA), and the State Infrastructure Bank (SIB). The main objective of the study is to evaluate innovative financing techniques associated with federal funds, and their applicability for transportation projects in Indiana. Possible legal, financial, and operational issues of various alternatives are examined. The economic impacts of innovative financing assistance are studied, looking at variables such as the user benefits of a project, in addition to debt service of the agency as many financing tools incur debt. Possible revenue sources for debt service payment also are identified, and from a legal perspective, factors such as eligibility, authorization parties, and administration of financing assistance are addressed.

\subsection{Methodology}

The evaluation of innovative financing techniques in this study is performed from an economical and legal perspective. Many 'what if' type questions are raised during the application of a certain financing technique to an individual project. Innovative financing assistance is applied on four of INDOT's future projects. These projects would require 
major financial investment and, with the use of traditional financing approaches, their completion (with the exception of SR 641 project) would not be realistic for many years into the future. Very limited information is currently available on three of the projects' economic characteristics, as environmental impact studies have not yet been completed. Therefore, a sensitivity analysis approach is utilized to measure the impact of innovative financing techniques on the economic viability of the projects, as well as on INDOT's debt service. This analysis indicates how sensitive the economic payoff is to uncertain values of critical input, such as interest rate, discount rate, and term of a loan or maturity of a bond. This approach is a powerful tool for investment appraisal studies where the effect of individual parameters can be studied.

\subsection{Report Organization}

This report consists of five chapters. Chapter 1 presents an implementation proposal. Chapter 2 illustrates the problem statement, specifies the objectives of the study, and describes the methodology used for analysis. Chapter 3 gives an overview of the current highway financing mechanism in Indiana and reviews the experiences of other states that apply innovative financing techniques. In Chapter 4, a detailed analysis is provided of major innovative financing techniques that could be applicable in Indiana and includes an investigation of the economic impacts of the selected INDOT projects and identification of possible additional revenue sources for debt service payments. The final chapter summarizes the findings of this study and gives the recommendations for further investigation and implementation. 


\section{CHAPTER 3. BACKGROUND INFORMATION}

\subsection{Current Transportation Financing Mechanism}

Transportation projects are generally financed on a traditional pay-as-you-go basis in Indiana, which assumes that adequate funding has been allocated for a project before it is begun. Currently there are three major sources of funding for the INDOT highway program.

\subsubsection{Federal Funds}

Since 1916, the federal government supported highway transportation investment through a grant-based strategy known as the Federal-Aid Highway Program (FAHP), and cash to liquidate incurred obligations for the FAHP came from the General Treasury Fund. Taxes on motor fuels and automobile products were already in existence but were not yet linked to funding for highways prior 1956. There were no revenues dedicated for transportation infrastructure financing as well. The Federal-Aid Highway Act of 1956 provided authorizations for fiscal years (FY) 1957 to 1969, and established the Highway Trust Fund (HTF) as a mechanism to collect revenue for financing the highway program. Revenues from existing motor fuel and automobile products taxes were accrued in the HTF and dedicated to financing highways. The act was extended several times by later successive legislations. TEA-21 extended authorizations for FY 1998 to 2003 and extended the Trust Fund through FY 2005.

The HTF was created as a user-supported fund, with revenues intended for financing highways from taxes dedicated to the HTF and paid by users of highways. This principle is still in effect but the revenue structure has changed over the years. Table 3.1 shows the types of taxes placed in the HTF and the rates currently in effect. 
Table 3.1. User Fee Structure [FHWA, 1999].

\begin{tabular}{|c|c|}
\hline Tax type & Tax rate \\
\hline Gasoline & 18.4 cents per gallon \\
\hline Diesel & 24.4 cents per gallon \\
\hline Gasohol (10\% ethanol) & 13 cents per gallon \\
\hline \multicolumn{2}{|l|}{ Special Fuels: } \\
\hline General rate & 18.4 cents per gallon \\
\hline Liquefied petroleum gas & 13.6 cents per gallon \\
\hline Liquefied natural gas & 11.9 cents per gallon \\
\hline M85 (from natural gas) & 9.25 cents per gallon \\
\hline Compressed natural gas & 48.54 cents per thousand cubic feet \\
\hline \multicolumn{2}{|l|}{ Tires: } \\
\hline $0-40$ pounds & No tax \\
\hline Over 40 pounds to 70 pounds & 15 cents per pound in excess of 40 \\
\hline Over 70 pounds to 90 pounds & $\$ 4.50$ plus 30 cents per pound in excess of 70 \\
\hline Over 90 pounds & $\$ 10.50$ plus 50 cents per pound in excess of 90 \\
\hline Truck and trailer sales & $\begin{array}{l}12 \text { percent of retailer's sales price for tractors and } \\
\text { trucks over } 33,000 \text { pounds gross vehicle weight } \\
(\mathrm{GVW}) \text { and trailers over } 26,000 \text { pounds GVW }\end{array}$ \\
\hline Heavy vehicle use & $\begin{array}{l}\text { Annual tax: Trucks } 55,000 \text { pounds and over GVW, } \\
\$ 100 \text { plus } \$ 22 \text { for each } 1,000 \text { pounds in excess of } \\
55,000 \text { pounds (maximum tax of } \$ 550 \text { ) }\end{array}$ \\
\hline
\end{tabular}

Fuel taxes provide the greatest income to the Highway Trust Fund, including 18.4 cents per gallon tax on gasoline and 24.4 cents per gallon tax on diesel fuel, as shown in Figure 3.1. Other Highway Trust Fund income results from an excise tax on heavy vehicle use and truck tires, and a retail tax on new trucks. 


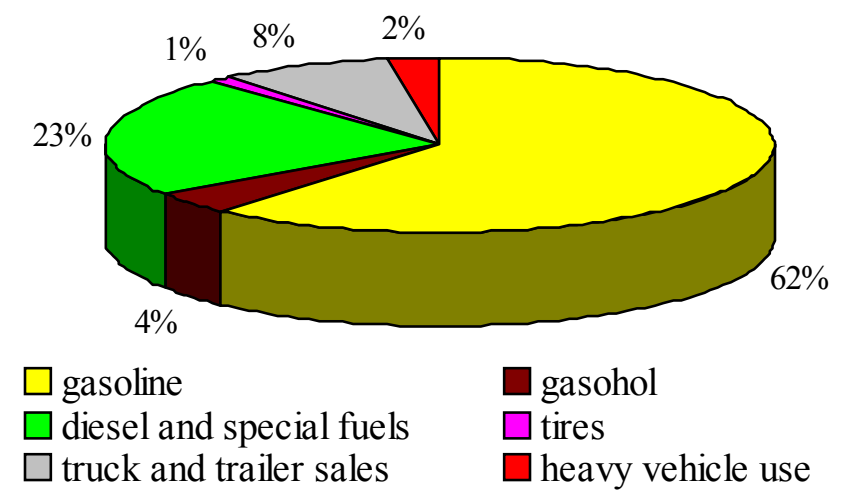

Figure 3.1 The Structure of the Highway Trust Fund Revenues in 2000 [FHWA 2001].

Since 1957, revenues derived from the federal gas tax and other excise taxes have been credited to the Federal Highway Trust Fund (FHTF) for allocation among states based on various formulas for reimbursement of eligible capital costs. Under this approach, the U.S. Department of Transportation (DOT) reimburses expenditures on transportation infrastructure at prescribed federal matching rates, while the remaining project costs are covered by the state [FHWA, 1999]. Most of the construction projects are financed by matching federal and state funds. The federal share comprises up to 80 percent of the total project cost, and the remaining 20 percent must be covered by the state.

Indiana is a donor state, which means that it contributes more to the FHTF than it receives in benefits. TEA-21 guarantees that each state will receive at least a 90.5 percent return on the share of money it contributes to the FHTF. The FHWA apportionment for Indiana was $\$ 773.52$ million for FY 2001, which was the 90.5 percent minimum guaranteed return exactly.

Although FHWA apportions funds to each state, there are spending limits according to obligation authority. For example, the general obligation limitation was 87.1 percent for INDOT in FY 2001, which means, for most funds, only 87.1 percent of the apportionment could be actually spent. In addition, it has been a long-standing practice that INDOT shares the apportioned federal funds with local communities, with INDOT receiving $75 \%$ of the funds after the obligation limitation. 
The FHTF supports highway, highway and motor carrier safety, and intermodal and transit programs. These programs generally have direct contract authority, but the cash to reimburse the state for the federal share of the project costs still must be released from the FHTF by an appropriations act. Any allocated funds not used during the current fiscal year can be carried over for use in the next fiscal year.

\subsubsection{State Funds}

The state generates funds for its highway projects from "user" (vehicle license fees, gasoline tax, tolls, etc.) and "non-user" sources (state's general funds and bonds). For the majority of states, the main portion of transportation funding comes from state motor fuel taxes and vehicle license fees. The major revenue sources that form the Indiana State Highway Fund are:

- gasoline tax (scheduled to increase to 18 cents/gal from 15 cents/gal in January 2003),

- diesel tax (16 cents/gal),

- $\operatorname{surtax}(11$ cents/gal for large trucks), and

- vehicle registration fees.

In addition to federal funds, INDOT collected $\$ 587.9$ million in the State Highway Fund in FY 2000 (Table 3.2). Not all of the collected revenues go directly into the State Highway Fund, however, as a certain portion of these funds is channeled to other transportation programs or sectors, such as the State Police, Bureau of Motor Vehicles, local roads and streets, etc. The Motor Carrier Fuel Use Tax is the only fuel tax that fully goes to the State Highway Fund. 
Table 3.2 Indiana State Transportation Revenues in FY 2000 (in million dollars) [INDOT, 2001a].

\begin{tabular}{|l|c|c|}
\hline & Total Collection & INDOT Share \\
\hline Fuel Tax Revenue & & \\
\hline Gasoline & 470.9 & 238.3 \\
\hline Diesel and Special Fuels & 181.9 & 85.4 \\
\hline Motor Carrier Surtax & 90.4 & 59.7 \\
\hline Motor Carrier Fuel Use Tax & 6.3 & 6.3 \\
\hline Non-Fuel Tax Revenue & & \\
\hline License \& Registration Fees & 268.1 & 142.6 \\
\hline Permits & 13.0 & 13.0 \\
\hline State Court Fees & 3.6 & 1.6 \\
\hline Sale of Property, Plans and Equipment & 2.0 & 2.0 \\
\hline Other / Miscellaneous & 46.3 & 38.9 \\
\hline Total & 1082.5 & 587.8 \\
\hline
\end{tabular}

As it is for the FHTF, gasoline tax is the major revenue source for transportation funding in Indiana (Figure 3.2), comprising almost 40 percent of total revenues. The second major source is license and registration fees (22.1 percent in the year 2000).

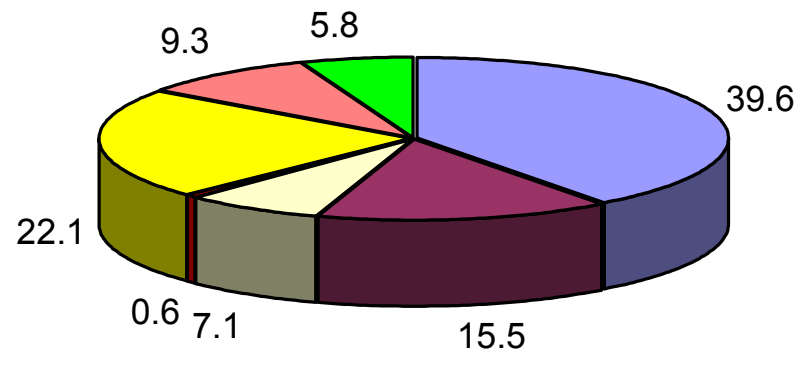

$\square$ Gasoline

$\square$ Diesel and Special Fuels

$\square$ Motor Carrier Surtax

Motor Carrier Fuel Use Tax

$\square$ License \& Registration Fees

General Fund

Other / Miscellanious

Figure 3.2 Revenue Sources for Transportation in Indiana in FY 2000 (\%)

$$
\text { [INDOT, 2001a]. }
$$


The Indiana State Highway Budget is divided into several categories:

- Operating - includes funding for all INDOT administrative expenses (utilities, staffing, office supplies, travel, fuel, etc.)

- Program Support - provides funding for research programs, buildings and grounds, vehicles, and road maintenance equipment

- Maintenance Program - funding meant for road maintenance agreements and contracts

- Right of Way - funds necessary for land acquisition to support planned projects

- Consulting - includes funding for capitalized design costs

- Construction - provides funding for construction contract costs

- Road Leases - funding for payments to the Indiana Transportation Finance Authority (ITFA) for use of their debt-financed roads [INDOT, 2001a].

Construction funding is the largest line item in INDOT's highway budget, with $55-60$ percent of the budget allocated for construction projects (Table 3.3).

Table 3.3 The Use of INDOT Budget (in million dollars).

\begin{tabular}{|l|c|c|c|c|}
\hline Category Year & 1999 & 2000 & 2001 & 2002 \\
\hline Operating & 202 & 204 & 217 & 221 \\
\hline Program Support & 31 & 36 & 44 & 47 \\
\hline Maintenance Work & 59 & 62 & 63 & 61 \\
\hline Construction & 689 & 681 & 797 & 647 \\
\hline Consulting & 53 & 70 & 56 & 59 \\
\hline Right-of-Way & 35 & 51 & 49 & 46 \\
\hline Road Leases & 31 & 34 & 40 & 1133 \\
\hline Total & 1100 & 1138 & 1266 & 52 \\
\hline
\end{tabular}


The highway construction program has two distinct components: the preservation program and the capital improvement program. The preservation program focuses on preserving existing highways, roads, and bridges. Typical preservation projects include road resurfacing and rehabilitation, bridge rehabilitation, intersection improvements, interstate and non-interstate resurfacing, and rail/highway safety projects.

Capital improvement projects generally are new construction projects that add capacity to the existing highway system. Adding lanes to an existing highway and construction of new roads and interchanges, as well as major rehabilitation of existing interchanges, fall under this category.

The construction budget has been mainly used for the following type of work:

- Bridge replacement and reconstruction,

- Interstate and non-interstate preservation,

- Intelligent Transportation Systems,

- Roadside and parking safety, and

- Major new construction.

Scheduled preservation projects receive the first priority of funding, after which capital improvement projects are considered. There are some sources of state revenue that are allocated solely for major new construction projects, and include the State Highway and Road Construction and Improvement Fund (SHRCIF), the Crossroads 2000 Fund, and bond proceeds.

The Indiana legislature created SHRCIF in 1988, by stipulating the first cent of gasoline tax paid for each gallon would go exclusively to the Construction and Improvement Fund for new construction projects. The SHRCIF collected $\$ 49.3$ million in 1999 and $\$ 50.7$ million in 2000 [ITFA, 2000].

The Crossroads 2000 Fund [ITFA, 2000] was established in 1997 after an increase in vehicle license and registration fees to provide continued funding for major state highway improvement projects. The rate increase portion goes directly to the Crossroads 2000 Fund. This fund is used for the pay back of bonds issued to finance new construction projects. In 1999 \$52.4 million was collected in this fund and \$35.3 million was collected in 2000 . 


\subsubsection{Bond Program}

For the last decade INDOT has used the highway bond program to fund major highway improvements and other new construction projects. The bond program is managed by the Indiana Transportation Finance Authority (ITFA) and was established in 1988 under Indiana Code 8-9.5-8 [ITFA, 2000]. The ITFA is a corporate body, separate from the state, and has no taxing power. Any indebtedness incurred by the ITFA does not constitute an indebtedness of the state. Indiana law forbids the state from contracting debt. The ITFA assists the state in acquiring funding for specific projects through a bond program.

The ITFA is authorized to:

- Undertake projects to construct, acquire, reconstruct, improve, and extend the state's highways, bridges, streets, and roads;

- Lease such projects to the Indiana Department of Transportation; and

- Issue revenue bonds to finance or refinance such projects.

The ITFA has issued revenue bonds to finance such projects since 1990 (Table 3.4).

Table 3.4 Summary of the Bond Program [ITFA, 2000].

\begin{tabular}{|l|c|c|c|c|c|c|}
\hline & 1990 & 1992 & 1993 & 1996 & 1998 & 2000 \\
\hline Issue date & $\begin{array}{c}\text { Jun 27, } \\
1990\end{array}$ & $\begin{array}{c}\text { Feb 27, } \\
1992\end{array}$ & $\begin{array}{c}\text { Apr 20, } \\
1993\end{array}$ & $\begin{array}{c}\text { Jan 9, } \\
1997\end{array}$ & $\begin{array}{c}\text { Jul 9, } \\
1998\end{array}$ & $\begin{array}{c}\text { Nov 2, } \\
2000\end{array}$ \\
\hline $\begin{array}{l}\text { Principal } \\
(\$ \text { million })\end{array}$ & $\$ 72.5$ & $\$ 74.0$ & $\$ 193.5$ & $\$ 27.1$ & $\$ 175.4$ & $\$ 269.5$ \\
\hline $\begin{array}{l}\text { Interest rate } \\
(\%)\end{array}$ & $7.2-7.4$ & $6.1-6.8$ & $5.0-6.25$ & $4.4-6.0$ & $4.25-5.5$ & $4.5-5.6$ \\
\hline Maturity & $6 / 1 / 2015$ & $12 / 1 / 2016$ & $6 / 1 / 2018$ & $12 / 1 / 2009$ & $12 / 1 / 2022$ & $12 / 1 / 2025$ \\
\hline $\begin{array}{l}\text { Maximum } \\
\text { annual debt } \\
\begin{array}{l}\text { service } \\
(\$ \text { million })\end{array}\end{array}$ & $\begin{array}{c}\$ 6.7 \\
(2013)\end{array}$ & $\begin{array}{c}\$ 6.4 \\
(2011)\end{array}$ & $\begin{array}{c}\$ 27.5 \\
(2018)\end{array}$ & $\begin{array}{c}\$ 4.0 \\
(2004)\end{array}$ & $\begin{array}{c}\$ 19.1 \\
(2011)\end{array}$ & $\mathrm{N} / \mathrm{A}$ \\
\hline
\end{tabular}

All bond instruments carry risk, including the creditworthiness of the issuer of the debt. Creditworthiness is the ability of the issuer to make the scheduled interest payments and to repay the principal when the bonds mature [Faerber, 2000]. 
There are independent rating services that evaluate the credit risk of municipal bonds. According to Standard \& Poor's (S\&P) [Faerber, 2000], bonds with ratings of $\mathrm{BBB}$ and above (A, AA, AAA) are considered to be investment-grade quality. Bonds with ratings below $\mathrm{BBB}$ (BB, B, CCC, CC, C, DDD, DD, D) are considered to be "junk" bonds with higher risk and greater coupon rates.

Most of the bonds issued by the ITFA have received a rating of A, which are interpreted as bonds that have strong capacity to repay principal and interest but may be impaired in the future [Faerber, 2000]. Bonds issued in 1996 received a rating of B, which means that the interest or principal of these bonds are neither highly protected nor poorly secured [Faerber, 2000].

Credit ratings provide only a point-in-time guide for investors because the financial status of the issuer can deteriorate or ameliorate over time. The risk of bonds depends on the issuer's financial health and ability to raise revenue.

The ITFA's bonds are corporate obligations of the ITFA, and are payable, as to both principal and interest, solely from revenues derived from leases with INDOT, bond proceeds and investment earnings on bond proceeds. Debt service on the bonds is payable primarily from rental payments received from INDOT [ITFA, 2000].

A part of the highway revenue collected in Indiana in the following funds is earmarked for bond repayment:

1. State Highway Road Construction and Improvement Fund (SHRCIF) and

2. Crossroads 2000 Fund (CR 2000).

The General Assembly in 1988 increased the state gasoline tax from 14 cents to 15 cents per gallon and required that one-fifteenth of the collected amount be transferred and deposited monthly into SHRCIF. This fund is used for bond repayments only. In 2002, the Indiana legislature increased the state gasoline tax from 15 cents per gallon to 18 cents per gallon. It will generate about $\$ 99$ million. Two-thirds of it will be allocated to state highways.

The CR 2000 Fund consists of deposits by the Bureau of Motor Vehicles (BMV) of certain fee increases collected by the BMV. Starting January 1, 1998, the BMV increased fees for driver's licenses and permits, motor vehicle registration, and license plates and motor vehicle certificates of title [ITFA, 2000]. 
These two sources provide sustained funds for repayment of General Obligation (GO) bonds, and since their inception, SHRCIF and Crossroads 2000 Fund have been able to cover annual debt service. Before new bonds can be issued, the ITFA has to look at the state's ability to make bond repayment. The viability of the bond program can be determined using debt service coverage ratio.

$$
\text { Debt Service Coverage Ratio }=\frac{\text { Annual Earnings }}{\text { Annual Debt Service }}
$$

Although the CR 2000 Fund is used to make lease payments for projects funded from bond proceeds, as well as to fund state highway projects directly, a major part of it is used for debt coverage. Therefore, the total resources available in the CR 2000 Fund are used in the calculation of the debt service coverage ratio (Table 3.5).

Table 3.5. Debt Service Schedule for $2001-2006$

(in million dollars) [ITFA, 2000].

\begin{tabular}{|l|c|c|c|c|c|c|}
\hline Revenues & 2001 & 2002 & 2003 & 2004 & 2005 & 2006 \\
\hline SHRCIF & 50.90 & 32.70 & 33.20 & 33.10 & 33.60 & 34.10 \\
\hline Crossroads 2000 & 51.10 & 37.60 & 38.30 & 39.10 & 39.90 & 40.70 \\
\hline Total & 102.00 & 70.30 & 71.50 & 72.20 & 73.50 & 74.80 \\
\hline Debt service payments & & & & & & \\
\hline Principal & 0.00 & 0.00 & 2.50 & 2.50 & 2.50 & 0.00 \\
\hline Interest & 2.03 & 5.86 & 11.55 & 14.60 & 14.48 & 14.43 \\
\hline Debt on prior bonds & 35.46 & 38.50 & 38.49 & 38.50 & 38.48 & 41.90 \\
\hline Total annual debt service & 37.49 & 44.36 & 52.54 & 55.59 & 55.46 & 56.33 \\
\hline Debt service coverage & 2.72 & 1.58 & 1.36 & 1.30 & 1.33 & 1.33 \\
\hline
\end{tabular}

Looking at the debt service coverage ratio, it appears that INDOT's debt burden may slightly increase in the coming years, and it may reach near the capacity of debt service funds to make lease payments for projects funded from bond proceeds. According to Table 3.5, the annual debt service is projected to increase continually each year. Most of the bonds issued by the ITFA have a maturity of 25 years, and were issued with a two- 
year time interval (except 1993 bonds) starting from 1990 (see Table 3.4). In 2003, total annual debt service will increase more rapidly than the projected revenues in the SHRCIF and the CR 2000 fund as the repayment of principal for the previous bond series will need to be made. Therefore, the debt service coverage ratio will start to decrease, and it is projected to be around 1.3 in proceeding years. The bond program therefore, as the source of funding, has nearly reached its limitations, and would not be able to hold significant further debt burden.

\subsection{Need for Innovative Financing}

INDOT has identified several future projects through a comprehensive process of the review of past planning studies, current planning programs, and the quantitative analysis provided by the application of the statewide system planning tools [INDOT, 2001b]. The identified projects have been documented as a need in INDOT's 2000-2025 Long Range Plan. To improve the state highway system, many capital improvement projects must be done, which as discussed in Section 3.1.2, comprises approximately onethird of the construction budget (Figure 3.3). Approximately 300 capacity expansion projects have been identified with a funding requirement of $\$ 6.7$ billion [INDOT, 2001b]. In recent years the amount available for capital improvement projects has been below $\$ 300$ million (Figure 3.3), while some of the individual projects under this program would require nearly $\$ 1$ billion. The amount available for capital improvements, realistically, is limited and not sufficient for large-scale project implementation. 


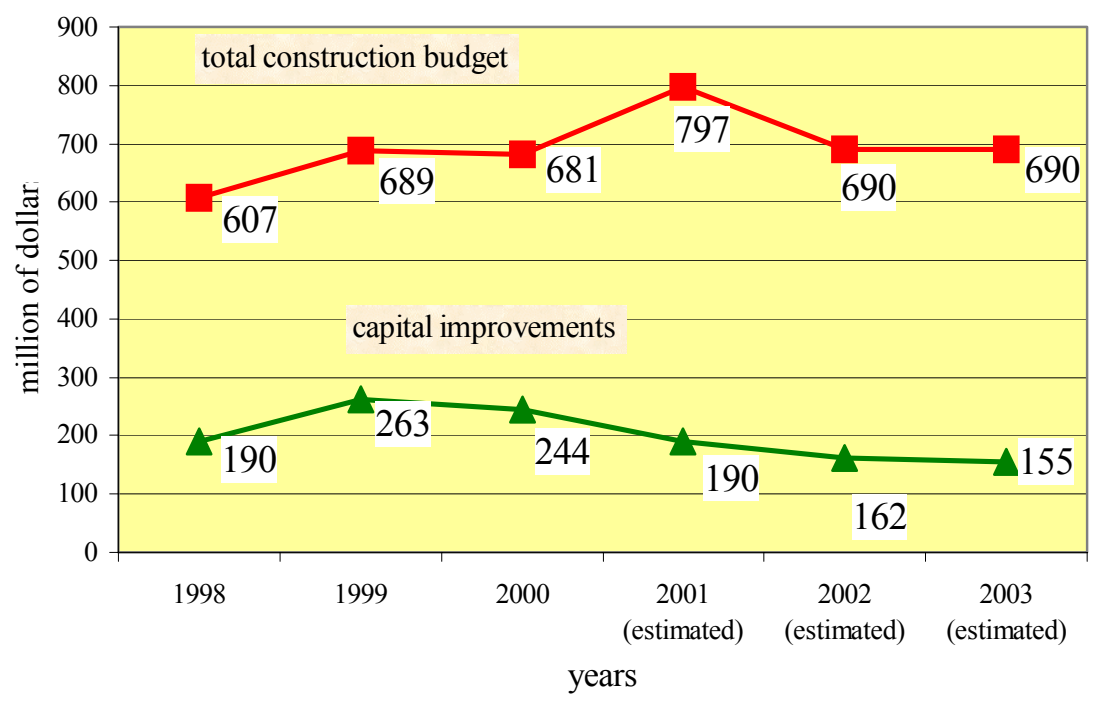

Figure 3.3 Funds for Capital Improvements within the INDOT Construction

$$
\text { Budget [INDOT, 2001] }
$$

The annual increase in recent years in INDOT's total construction funds, including federal and state sources, has been fluctuating. For future projections of its construction budget after 2003, INDOT has used a growth rate of two percent, which is less than the average annual inflation rate in the country (three percent) and insufficient for all identified projects of the Indiana state highway system. The current financing mechanism has certain restrictions in its use. The pay-as-you-go approach makes it difficult to save for large projects. Thus, such projects typically are built in multi-year segments or deferred indefinitely into the future, contributing to cost over-runs due to inflation, increased rehabilitations costs over time, and lost savings in user costs.

According to Giglio [2000] the current highway financing system in the U.S. has three fundamental structure problems: political barriers to raising user taxes, unpredictable revenues, and lack of linkage between user fees and highway system costs and benefits. The difficulty associated with increasing the fuel tax rate has resulted in insufficient revenues to maintain and improve the highway system. Increases in tax rates and user fees over the years have not been able to eliminate the difference between existing funds and the amount of projects an agency would like to implement. In addition to political uncertainty, highway revenues are subject to economic uncertainty. Fuel 
economy varies widely according to the mix and technology of vehicles in the fleet and the presence or absence of regulations.

The current highway user fee system is not directly related to the costs and benefits of the highway system. The pay-as-you-go approach cannot distribute the cost of a project equitably among the users over time, and it burdens the current users with the entire project cost. Most importantly, the current financing mechanism cannot provide enough timely capital for highway improvement. There are also many barriers to implementing new revenue-generating sources and increasing the level of existing ones. Hence, a possible solution is to increase the leveraging level of existing funds, applying non-grant innovative financing techniques in the areas wherever applicable.

\subsection{Innovative Financing: State-of-the-Practice}

Over the last decade the federal government has responded to the shortfall in conventional funding sources by providing new financing techniques that complement and enhance the federal-aid program by leveraging additional capital investment in transportation infrastructure. ISTEA established federal policies in 1991 designed to encourage innovative project management and financing strategies. In 1994, FHWA launched its TE-045 program, which spawned a variety of innovative tools applicable in transportation financing, and in May 1998 TEA-21 added a number of new tools to be used by sponsors of highway projects.

A widely accepted principle of public innovative finance today is to fund longterm projects with debt repaid over a similar term to a project's life, which cushions the annual impact on available cash flow. This approach, called "pay-as-you-use", is fair for highway users because it shares the costs, in the form of debt service payments, among both current and future users. Although the interest payments can significantly increase the costs of a project, the total benefit for users and the state may still be greater than a deferring project to the future [Seltzer, 2000].

Three prominent financing programs that have particularly attracted the attention of state transportation agencies are Grant Anticipation Revenue Vehicle (GARVEE) bonds, the Transportation Infrastructure Financing and Innovation Act (TIFIA), and the 
State Infrastructure Bank (SIB). Although these three programs differ, they share the concept of financing projects by leveraging federal assistance.

Many states have already elected to finance projects using some of these innovative financing techniques, including Massachusetts, Mississippi, New Mexico, and Ohio, which have financed more than $\$ 1$ billion of projects this way. Innovative techniques generally have been used in connection with single, large construction projects, such as the Boston Central Artery and New Mexico's Corridor 44 Project [Seltzer, 2000].

\subsubsection{GARVEE Assistance}

Several states in recent years have passed legislation authorizing the issuance of GARVEE bonds. GARVEE refers to a financing instrument for which principal and interest is repaid with future federal-aid highway funds. A more detailed description and analysis of this technique are discussed in Section 4.2. This technique is becoming a part of the standard state project financing feature.

The projects funded through GARVEE bonds by a number of states vary in complexity and cost, ranging from a $\$ 116$ million interchange reconstruction project in Ohio to the $\$ 10.8$ billion Central Artery Tunnel construction project in Boston, Massachusetts [Inman, 2000]. New Mexico, Colorado, Mississippi, Arkansas, Arizona, and California have also passed enabling legislation or already authorized the use of GARVEE bonds, for which nearly $\$ 1$ billion (Table 3.6) had been issued by the year 2000. 
Table 3.6 GARVEE transactions by year 2000 [Inman, 2000].

\begin{tabular}{|l|c|c|l|}
\hline \multicolumn{1}{|c|}{ State } & $\begin{array}{c}\text { Date of } \\
\text { issue }\end{array}$ & \multicolumn{1}{|c|}{$\begin{array}{c}\text { Amount of issue, } \\
\text { \$ in million }\end{array}$} & \multicolumn{1}{|c|}{ Project financed } \\
\hline New Mexico & Sep, 1998 & 100.2 & New Mexico State Route 44 \\
\hline Ohio & $\begin{array}{c}\text { May, 1998 } \\
\text { Aug, 1999 }\end{array}$ & 70.0 & Spring - Sandusky project \\
\hline Arkansas & Mar, 2000 & 175.0 & Interstate highways \\
\hline Colorado & May, 2000 & 537.0 & $\begin{array}{l}\text { Any project financed whole or } \\
\text { in part by Federal funds }\end{array}$ \\
\hline Arizona & Jun, 2000 & 39.4 & $\begin{array}{l}\text { Acceleration of freeway } \\
\text { projects }\end{array}$ \\
\hline \multicolumn{2}{|c|}{ TOTAL } & 941.6 & \\
\hline
\end{tabular}

Table 3.6 includes only direct GARVEEs, which have their debt service paid directly from the federal funds programmed for the project or with the project's bond proceeds. More states are becoming familiar with GARVEE funding. New legislation has been introduced in Alaska, Georgia, and Texas during recent years in favor of GARVEE bond issuance. As of December 2001, pending passage of the bill, Alaska planned to sell $\$ 442$ million bonds as a single issue. Debt service requirements were anticipated to account for 11 percent of Alaska's roughly $\$ 350$ million annual federal highway apportionments [Brown, 2001].

Members of the Texas legislature have filed three separate constitutional amendments that would authorize the Texas Transportation Commission to issue GARVEE bonds. A substitute measure passed by the senate permits use of the proceeds to fund statewide improvements to the highway system based on the following criteria:

1) potential cost savings, economic and environmental benefits, and other benefits associated with completing the project earlier than would be possible using traditional methods of funding; and

2) the effect on the state's transportation system.

The substitute measure limits annual debt service to not more than five percent of the state's annual federal-aid spending limit. Texas' federal aid apportionment for FY 2001 was $\$ 2.2$ billion [Brown, 2001]. 
GARVEE bonds allow states to complete large long-term projects more quickly than using the traditional financing procedure. For instance, New Mexico State Highway and Transportation Department (NMSHTD) was looking for possible financing sources to reconstruct and expand the two-lane State Route 44 into four lanes in a reasonable time period at a reasonable total cost [Trujillo, 2000]. By using the standard NMSHTD project delivery process, the 118-mile project would have taken up to 27 years. However, NMSHTD conceived an innovative public-private financing approach whereby the state issued \$295 million of GARVEE bonds with the sole source of repayment being future federal funds without any state guarantee, creating a virtual $100 \%$ federal-aid project. The use of this innovative financing technique allowed completion of the project in three years, instead of 27. The savings were not only realized in the final construction costs due to the economies of scale, but were also evident in administrative and maintenance costs that would be added by a 27 -year term [Trujillo, 2000].

\subsubsection{SIB Assistance}

Several case studies have been done using State Infrastructure Bank (SIB) assistance, which is capitalized from federal and state funds and operates like a private bank offering loans and credit enhancement products [FHWA, 1997c]. Section 4.4 of this report will explain how SIB works. An SIB pilot program started with 10 participating states and has grown to include 32 states and 204 loan agreements, totaling over \$2.4 billion through March 2001 (Appendix B). The most active SIBs are in Arizona, Florida,

Maine, Michigan, Ohio, Pennsylvania, and Texas. Seventy-three percent of all agreements under the SIB program have been signed in these states [Jones, 2001].

The State Road 80 (SR 80) interchange project, located at the junction of SR 80 and the Florida Turnpike, Palm Beach County, Florida, is an example of SIB assistance [FHWA, 1997c]. The preferred alternative for the interchange design was a full cloverleaf, which would provide the highest level of service at the lowest cost. The estimated cost of the project was $\$ 22,350,000$. The financing structure for the SR 80 project was influenced by Florida statutes, which prescribe a test for financial feasibility for projects financed from turnpike revenues: 
- turnpike system toll subsidies are limited to $50 \%$ of debt service costs during the first 15 years, and

- the project must generate sufficient incremental revenue to pay its incremental operating and debt service costs after 15 years of operation.

The SIB loan was structured to pay interest costs (\$11.3 million for the first eight years of operation) on the toll revenue bonds issued to finance the project, which met the first of the above financial tests. To meet the second condition, the State of Florida contributed \$11.3 million in subsidies, which were paid into an escrow account when the project became operational in July 2000 [FHWA, 1997c]. These subsidies were counted as the state match for the project. Thus, the flexibility offered by the SIB loan allowed the project to take advantage of potential revenue growth and defer the need for state subsidies in later years.

\subsubsection{TIFIA Assistance}

The Transportation Infrastructure Finance and Innovation Act (TIFIA) is designed to provide financing assistance through different credit products to projects able to provide their own non-federal repayment streams. The U.S. DOT has approved 10 projects since 1999 for TIFIA assistance, totaling nearly \$12 billion (Table 3.7). TIFIA would provide over $\$ 3.4$ billion in credit assistance for these projects at an estimated budgetary cost of \$194 million [Grote, 2000].

The approval process for TIFIA assistance is time consuming. Many legislative and administrative issues must be resolved related to the use of this innovative financing technique, i.e., revenue collection, negotiations with the U.S. DOT about credit instruments, and other processes. 
Table 3.7 TIFIA Project Selections [Grote, 2000; Seltzer, 2000].

\begin{tabular}{|l|c|c|l|}
\hline \multicolumn{1}{|c|}{ Project } & $\begin{array}{c}\text { Estimated } \\
\text { Project Cost } \\
\text { (in millions) }\end{array}$ & $\begin{array}{c}\text { TIFIA Credit } \\
\text { Request } \\
\text { (in millions) }\end{array}$ & $\begin{array}{c}\text { Type of Credit } \\
\text { Instrument }\end{array}$ \\
\hline Miami Intermodal Center (FL) & 1300 & 436 & Direct loan \\
\hline Farely-Pennsylvania Station (NYC) & 748 & $\begin{array}{c}140 \\
20\end{array}$ & $\begin{array}{l}\text { Direct loan } \\
\text { Line of credit }\end{array}$ \\
\hline State Route 25 (San Diego, CA) & 397 & 90 & $\begin{array}{l}\text { Loan guarantee } \\
\text { Line of credit }\end{array}$ \\
\hline Tren Urbano (San Juan, Puerto Rico) & 1700 & 37 & Direct loan \\
\hline $\begin{array}{l}\text { Washington D.C. Metro Capital } \\
\text { Program }\end{array}$ & 2300 & 600 & Loan guarantee \\
\hline Cooper River Bridge (SC) & 650 & 215 & Direct loan \\
\hline Staten Island Ferries and Terminals & 463 & 153 & Direct loan \\
(NY) & & & Direct loan \\
\hline Tacoma Narrows Bridge & 835 & 540 & Line of credit \\
\hline Central Texas Turnpike (TX) & 3200 & 800 & Direct loan \\
\hline $\begin{array}{l}\text { Reno Transportation Rail Access } \\
\text { Corridor (NV) }\end{array}$ & 242 & 80 & Direct loan \\
\hline
\end{tabular}

The Tren Urbano project in San Juan, Puerto Rico is the only one to date to have actually received TIFIA disbursements. The Puerto Rico Highway and Transportation Authority is developing a 17-kilometer rapid transit line to serve metropolitan San Juan. The $\$ 1.7$ billion project is expected to handle 100,000 trips per day in its first year of operation (2002). Assisted by $\$ 300$ million in TIFIA loan proceeds disbursed in August 2000, work on this new rail transit line for the City of San Juan reached 75 percent completion by the end of 2000 [FHWA, 2001].

Different innovative financing techniques appear to have assisted state transportation agencies to accelerate project completion. It is not yet possible to evaluate the impact of these techniques in the long run, as they have been in use only five years. Most of these techniques involve debt; therefore, a complete analysis could be conducted after the debt service is cleared. 


\section{CHAPTER 4. EVALUATION OF INNOVATIVE FINANCING TECHNIQUES}

The primary aim of innovative financing measures is to make funding available sooner than otherwise, possible to permit faster completion of the work, enabling such projects to yield user benefits sooner. Specifically, innovation in highway financing is achieved by fostering public-private partnerships; drawing on the public's willingness to pay direct user charges for transportation benefits and services; leveraging existing sources of capital; and enabling additional transportation facilities to be developed more quickly than would be possible under conventional public procurement, funding and ownership [FHWA, 1999c].

The three major innovative financing techniques that are currently being implemented in the U.S. are the State Infrastructure Banks (SIB), Grant Anticipation Revenue Vehicle (GARVEE) Bonds, and the Transportation Infrastructure Finance and Innovation Act (TIFIA), all of which have become available through the TE-045 program.

Figure 4.1 summarizes the various innovative financing techniques associated with federal assistance for surface transportation projects. The pyramid's shape reflects the relative number of projects in each funding category. The base of the pyramid represents the vast majority of projects that cannot generate revenues and, therefore, will continue to be dependent upon funding primarily through grants. The federal government has adopted enhanced fund management techniques, such as advance construction and grant-supported debt service to help move these projects to construction more quickly. 


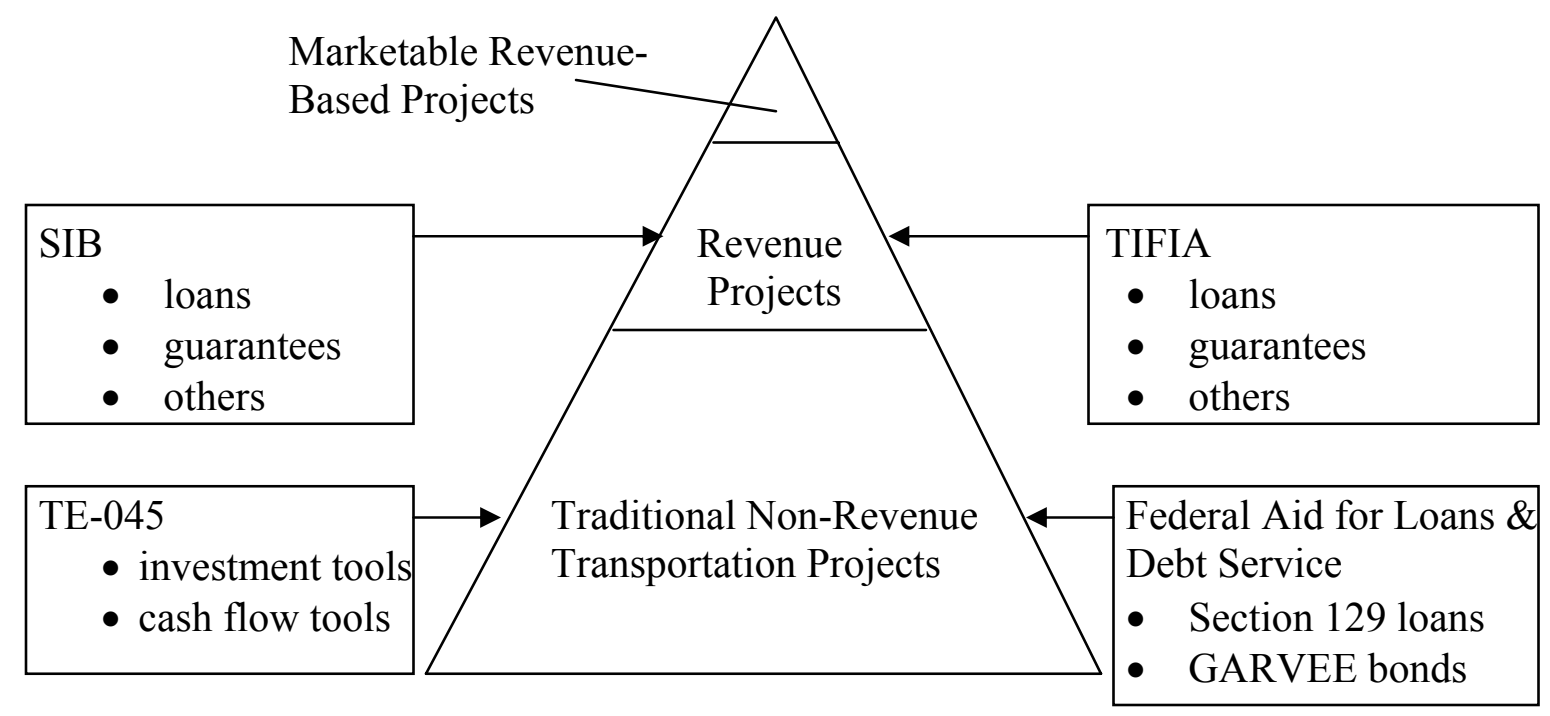

Figure 4.1 Federal Assistance for Transportation Infrastructure [FHWA, 1999c].

The middle layer of the pyramid (approximately 5-10 percent of total capital investment) represents those projects that can be at least partially financed with debt payable from project-related revenues, but which also may require some form of public credit assistance to gain market access. The SIB can offer many types of assistance, e.g., lower interest loans, guarantees, and other credit enhancements, to local or regional projects with revenue streams. The federal credit program established under the TIFIA, on the other hand is designed to assist large-scale projects generating major economic benefits that might otherwise be delayed or not constructed at all because of their risk, complexity, or cost.

The peak of the pyramid represents the very small number of projects that can arrange private capital financing without any governmental assistance. These relatively few projects may be developed on high-volume corridors where the revenues from user charges are sufficient to cover capital and operating costs. The following sections of this chapter describe each of the innovative financing techniques and their applicability and impact on the economic parameters of the chosen INDOT projects. 


\subsection{TE-045 Program}

The TE-045 program allows states to identify and test new financial opportunities within the federal-aid highway program. TE-045 was established in 1994 under Section 307(a) of Title 23 of the U.S. Code, which permits FHWA to engage in a wide range of research projects, including those related to highway finance [FHWA, 1997a]. Thus, FHWA is able to waive selected policies and procedures so that specific transportation projects can be advanced using non-traditional financing concepts.

TE-045 does not make new money available, rather its primary focus and ultimate measure of success is the program's ability to foster the identification and implementation of new, flexible strategies to overcome the fiscal, institutional, and administrative obstacles in funding transportation projects.

The necessity for a more flexible tool like TE-045 was recognized once the following drawbacks of the existing project financing mechanism were realized.

- States were required to set aside funds equal to the amount of the federal share of the cost of the project in the first year of construction, forcing states to pursue multiple projects sequentially rather than simultaneously.

- The traditional pay-as-you-go method was used for financing every project, even in cases when the pay-as-you-use strategy was more beneficial from an economic and financial perspective.

- Federal and state governments were the only participants in transportation project financing.

Some projects were being delayed as a result of these restrictions, and federal and state funds were almost unleveraged on the capital markets.

The objectives of TE-045 respond directly to these concerns, namely to increase investment in transportation projects and to accelerate project completion. The increase of investment can be achieved by assisting states to leverage their current spending by attracting additional capital, both public and private. Having additional capital, projects can be realized more quickly than under the traditional financing mechanism. 


\subsubsection{TE-045 Financing Tools}

TE-045 provides several financing tools to achieve its objectives, which can be divided into two categories, investment tools and cash flow tools.

\section{Investment tools}

Generally aimed at increasing the total amount of resources available for transportation projects, investment tools raise the capital at a time earlier than ordinarily provided by federal and state government. There are four principal investment tools:

\section{Flexible match}

A state is allowed to substitute private contributions for the required state match.

\section{Section 129 loans}

Initially, Section 129 of Title 23 of the U.S. Code allowed a state to make loans to a public or private entity constructing a toll project. These loans were eligible for federalaid funding or a non-toll highway project with a revenue source specifically dedicated to support the project [FHWA, 1997]. The NHS Designation Act of 1995 amended Section 129 to allow states to also offer loans to non-toll projects.

\section{Toll credits}

This tool permits states to substitute certain expenditures on the state toll system, which effectively raises the federal share to 100 percent [Roskin, 1997].

\section{Reimbursement of bond financing costs}

It expands the types of bond-related costs for federal reimbursement, including interest, issuance, and administrative costs, as well as principal payments.

\section{Cash flow tools}

Cash flow tools aim to move projects to construction sooner by providing flexibility in the rules that govern a state's obligation of federal-aid funds and 
reimbursement of the state's expenditures. These tools allow realizing the benefits associated with a particular project sooner. The cash flow tools are:

\section{Advance construction}

With this tool a state may use its funds to complete the project while still preserving the project's eligibility for future federal-aid reimbursement. This cash flow tool may extend the eligibility for reimbursement into the next authorization period beyond TEA-21.

\section{Partial conversion of advance construction}

This tool permits a state to convert an advance construction project to a federal-aid project in a graduated fashion, thereby phasing the obligations over a period of several years [Roskin, 1997].

\section{Tapered match}

This tool permits states to vary the standard matching ratio ( 80 percent federal funds and 20 percent state funds) if a state does not have enough funds readily available for a project. It allows the state to start a project with 100 percent federal funds and taper the match, so long as the required standard matching ratio is preserved on a cumulative basis.

\section{Phased funding}

This tool allows a state to obligate the amount for a project approximate to the amount actually spent for a completed project in a phased fashion. Phased funding has not been tested in TE-045 since 1996.

\subsubsection{The States' Response to the Program}

An evaluation of TE-045 was performed in fall 1996, two years after its initiation. Thirty-seven states had submitted proposals for 88 projects in that time [Roskin, 1997]. Seventy-one projects were approved in 29 participating states with a total value of $\$ 4.2$ billion, which consisted of a federal investment of $\$ 2.2$ billion, a state investment of $\$ 0.4$ 
billion and other investments (private, local, toll authority) of $\$ 1.6$ billion [Roskin, 1997].

As stated above, TE-045 proposes a broad range of innovative financing techniques suited to diverse needs. There is a wide variation in each state's level of interest in these tools. For projects being pursued under TE-045 the most popular financing tools are those that give flexibility in use of existing state and federal funds (see Table 4.1).

Table 4.1 Use of Innovative Financing Tools under TE-045 [FHWA, 1997].

\begin{tabular}{|l|c|}
\hline Tool & Number of Projects \\
\hline Flexible match & 28 \\
\hline Advance construction & 15 \\
\hline Partial conversion of advance construction & 14 \\
\hline Phased funding & 9 \\
\hline Tapered match & 5 \\
\hline Section 129 loan & 5 \\
\hline Toll credits & 3 \\
\hline Bond reimbursement & 2 \\
\hline Other (alternative financing strategies) & 2 \\
\hline
\end{tabular}

More than one tool can be used in a project's financing, therefore, the number of projects mentioned in Table 4.1 total more than 71. Partial conversion of advance construction was most commonly used in conjunction with other tools [FHWA, 1997]. As shown in Table 4.1, flexible match and certain cash flow tools were the most commonly utilized.

A number of factors contribute to the varying interest in the individual TE-045 tools, an important factor being a tool's applicability to different situations. Some tools are more universal (flexible match, advance construction) while other tools have a narrower scope of applicability (toll credits).

Another factor is the level of effort associated with the use of a particular tool. Some tools, such as advance construction, do not require any special action to implement. Other tools, like bond reimbursement and Section 129 loan, may require institutional and legislative changes within the state. 
A critical constraining factor to using certain tools is a lack of additional federal funding to support implementation of TE-045. When a state uses federal funds to reimburse bond cost or a loan, part of its annual federal apportionment is consumed. States are free to choose whether to apply any of the innovative financing tools to an individual project's financing. All the critical factors should be carefully examined before making decision about the techniques to fund a project.

\subsubsection{Effects of the Program}

The innovative financing concepts available under TE-045 produce significant quantitative and qualitative benefits in transportation financing. The quantitative benefits can be realized in two primary categories: raised funds at a time earlier than ordinarily provided through annual federal apportionments and accelerated project execution. In general, investment tools such as flexible match and Section 129 loans play the greatest role in providing funds upfront to transportation projects. Cash flow tools, such as partial conversion of advance construction, offer the primary benefit of accelerating projects by permitting states to alter the timing and administration of federal funds to better match construction timetables. At the same time, the benefits associated with investment and cash flow tools are not mutually exclusive, as two or more tools can be used on a single project.

Completing a project more quickly gives another financial advantage - avoidance of inflation costs. Inflation savings can be particularly significant in highway projects as some types of expenditures can escalate at a higher rate than the standard rate of inflation. For example, the cost of acquisition of right-of-way may increase over time due to rising land costs in areas of rapid commercial and residential growth.

Altering the timing of apportioned federal funds allows for accelerated completion of large, high priority projects that would otherwise be deferred due to insufficient funding. Expediting realization of a project generates savings in highway user costs and other economic benefits sooner. 


\subsection{Grant Anticipation Revenue Vehicle (GARVEE) Bonds}

Grant Anticipation Revenue Vehicle (GARVEE) bonds offer states an innovative way to assemble up-front capital by allowing a state to pledge future federal-aid funds to repay investors.

Prior to 1995, states could use their federal highway grants to repay only the principal component of debt service on most projects. This restrictive rule was out of sync with the cash requirements for annual debt service payments since the predominant component of debt service during the years of debt retirement is interest expense [Long, 1999].

Section 311 of the National Highway System (NHS) Designation Act of 1995 significantly expanded the eligibility of bond and other debt financing costs for federalaid reimbursement. This significant change to the federal-aid program was codified into permanent highway law as an amendment to Section 122 of Title 23, U.S. Code [FHWA, 1999], which declares that a state may use future obligations on federal-aid funds to reimburse principal and interest payments of bonds, and to cover bond issuance costs, insurance, and other costs incidental to the sale of an eligible debt-financing instrument. In all cases, the project for which the debt has been issued must be eligible for federal-aid funding.

A GARVEE can be any bond, note, certificate, mortgage, lease, or other debtfinancing instrument issued by a state or political subdivision, whose principal and interest is repaid primarily with federal-aid funds under Section 122 of Title 23, U.S. Code. The federal government does not guarantee bonds. The funds are used only to repay debt service through a federal-aid program.

The advantage of GARVEE bonds in the financial market is their special tax treatment. The interest received from these bonds is exempt from federal income tax, as well as tax in the state in which bonds were issued. That benefits investors in case when the equivalent yield of a taxable bond is greater than the rate on a taxable bond in the market [Faerber, 2000]. Tax exemptions benefit not only investors who buy bonds but also the state issuing them since it can pay lower coupon yields than on regular taxable bonds. 


\subsubsection{Project Approval}

To receive federal-aid funds for debt payments a project must be approved by FHWA as a federal-aid bond issue project [FHWA, 1999]. Once a state estimates its costs for a project and selects GARVEE bonds as the method of financing, a project must be approved as an advance construction (AC) project by FHWA. The AC designation preserves the project's future eligibility for federal assistance. A state independently raises the upfront capital required for a project by issuing GARVEE bonds, and at a later date, federal-aid highway funds can be obligated for reimbursement of the federal share.

Figure 4.2 shows the steps that should be considered to receive the federal-aid reimbursement for debt service payments.

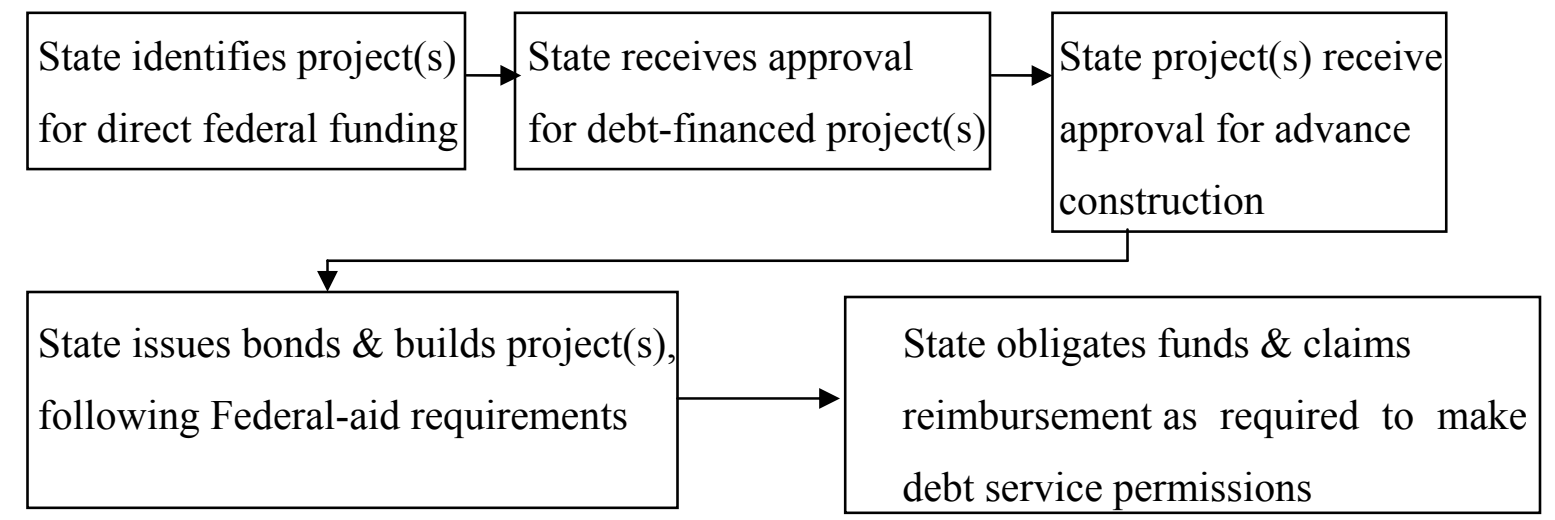

Figure 4.2 Procedure for Receiving Federal-Aid Reimbursement Using GARVEE Bonds

Securing advance construction status for a project allows a state to access a variety of capital sources, including GARVEE bonds, to accelerate project completion. A project can get approval from FHWA for a debt-financed project in order to receive debt service reimbursements, but FHWA does not approve bond issuance, which is under state authority [FHWA, 1999].

GARVEE bond funding, similar to "regular" project funding, should follow the general match between federal and state funds, 80 percent and 20 percent respectively, on the debt-related costs anticipated to be reimbursed during the life of the bonds. It does not necessarily mean that 100 percent of the project costs should be debt-financed. The 
federal and non-federal share may be financed differently. For example, the federal share may be debt-financed, while the state share may be funded on a traditional "pay-as-yougo" basis or toll credits.

\subsubsection{GARVEE Funding at Work}

When the GARVEE bonds are issued, the main form of security backing is the state's obligation of future federal apportionments. FHWA anticipates that the state would designate an advance construction amount up-front, and then obligate funds in each succeeding year. Each year the GARVEE bond issuer would pay the annual debt service through payments received from FHWA as a federal share of the total cost. Cash flow for bond funding can be illustrated in a simple diagram (Figure 4.3).

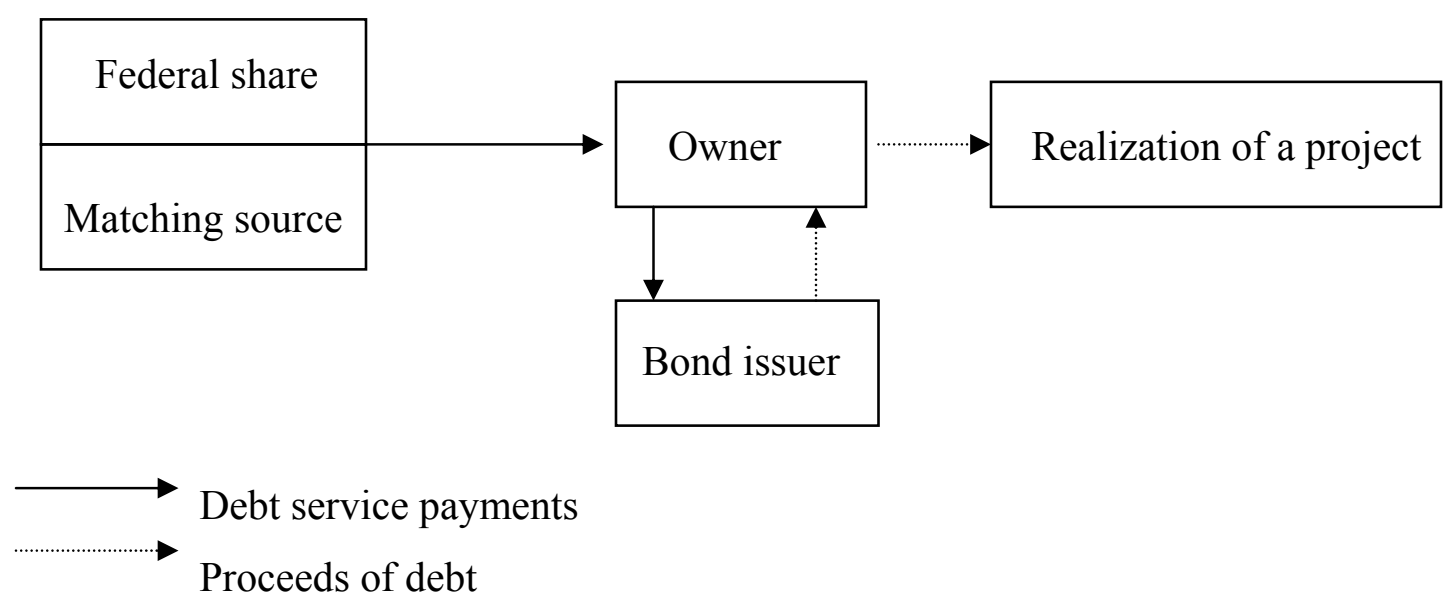

Figure 4.3 Cash Flow in GARVEE Financing Model.

Figure 4.3 shows that the owner manages the cash flow in a GARVEE financing model and is responsible for both the proceeds and the repayment of debt. Payments occur periodically over the life of the debt.

The owner and the bond issuer may be the same entity. In state of Indiana the bond issuer could be the Indiana Transportation Finance Authority since the state is not allowed to be indebted. A description of the Authority is given in Section 3.1.3.

Federal law authorizes two types of GARVEE bonds: direct and indirect [Long, 1999]. Direct GARVEE bonds are financed by future federal reimbursements for a 
specific project or several projects. The $\mathrm{AC}$ designation requires that the project be contained in the State Transportation Improvement Program (STIP) and ensures the project's future eligibility for federal-aid funds.

Indirect bonds are repaid by federal funds that the state receives as reimbursement for other transportation projects and are not marked for specific project financing. Once the state receives the reimbursement, the federal funds are considered to be state funds. As such, these funds are free from federal requirements regarding the types of projects that the money can be used to finance or any other federal requirements. Thus, indirectly the state can use federal money for debt service payments [Long, 1999]. In the case of both direct and indirect GARVEE bonds, the state must demonstrate its ability to pay its share (usually 20 percent).

\subsubsection{GARVEE Bonds in the Financial Market}

The purpose of financial markets is to allocate capital efficiently in an economy during a period of time to parties who use funds for investment in real assets or for consumption [Van Horne, 2001]. The role of GARVEE bonds in the financial market is to raise funds for investment in transportation projects. GARVEE bonds, like any other type of bonds, carry risk. The rating agencies define the level of risk by giving ratings to the bond program before the bonds have been issued and update the rating throughout the bond's life. Bond ratings are described in Section 3.1.3.

Previous experience by the states with bond issuance indicates that the bond market views GARVEE bonds favorably. In all cases, they have received strong, investment grade ratings from rating agencies. For example, New Mexico, Colorado, Massachusetts, and Ohio's GARVEE bonds have received ratings of AAA, AA3, AA3, and AA3 respectively from Moody's rating service [Long, 1999]. In all cases, the interest rate on the GARVEE bond was relatively close to the rate of the state's General Obligation (GO) bond. The interest rate on a GARVEE bond issued in Colorado was between five and six percent depending on maturity. The first bond sale was closed on June 1, 2000 [Long, 1999]. 
The value of GARVEE bonds in the financial market depends largely on the predictability of the revenue stream. Revenues can be analyzed in the short-term or longterm periods, and TEA-21 substantially reduced the short-term risk of GARVEE bonds by providing states with a minimum guarantee of federal funding. TEA-21 authorized a total of $\$ 218$ billion for highways, highway safety, and transit, thereby providing states with this minimum guarantee and substantially reducing the risk until 2003 when the authorization period for TEA-21 ends. Although it is considered very unlikely that federal transportation allocations will diminish beyond 2003, there is also no guarantee that the level of funding provided by the federal government will remain stable. Thus, GARVEE bonds are subject to some inherent risk.

GARVEE bonds can be analyzed as long-term debt instruments if they are backed by future federal-aid funds for a term that is beyond the current federal-aid authorization act. The long-term risk assessment would also include the risk of the federal-aid program being reauthorized in the future. GARVEE bonds are considered to be riskier than GO bonds. Debt service payment for GARVEE bonds is not guaranteed by the federal government even though it provides the major portion of funding, whereas GO bonds are fully secured by the state.

To increase the credit rating on a GARVEE bond, states may provide some type of funding backstop in case federal funds are not sufficient to meet bond payments. Massachusetts and Ohio structured their debt so that other state transportation funds may be sought in the event of unexpected federal fund shortfalls. Massachusetts marked 10 cents of its 21-cent state fuel tax towards GARVEE bond repayment in the event of a federal funding shortfall [Long, 1999]. New Mexico chose to purchase municipal bond insurance, which increased the credit rating on the bond from A3 (still considered investment grade) to AAA (the highest possible rating), which resulted in about $\$ 500,000$ savings over the life of the bond due to lower coupon rate [Long, 1999].

\subsubsection{Pros and Cons of GARVEE Bonds}

The criteria for determining when GARVEE bonds would be an appropriate funding mechanism are largely the same as those that would apply in considering any 
type of bond financing. Before states were eligible for any kind of bond program, they relied mainly on pay-as-you-go financing for transportation projects. When existing revenues are sufficient to fund a project, pay-as-you-go financing is generally preferable over bond financing as it avoids debt service cost. However, this approach may not be desirable for large, high-priority projects as it may be difficult to accumulate enough funds and a project may be stretched into multi-year segments. Delays also may then contribute to project cost over-runs due to inflation. In such cases, bond financing may be a better approach.

Bond financing allows a project to be built sooner and can be more cost-effective by avoiding initial project cost increases resulting from inflation. Furthermore, bond financing can provide road users with benefits sooner than what would be possible with traditional financing.

GARVEE bonds also contain some unique characteristics that should be considered when choosing between different financing options.

- The state does not have to use its own funds to fully support a project, as required with highly rated $\mathrm{GO}$ bonds.

- A GARVEE bond may get a higher credit rating than a GO bond due to the proportion of federal funds specified for debt payment.

- A GARVEE bond may be used as a financing technique when a revenue stream is not available for the project as it would be with revenue bonds.

- Indirect GARVEE bonds allow a project or a group of projects to be funded with federal funds without being subject to various federal requirements attached to the use of such funds [Marx, 2000].

- The GARVEE program is not limited to any type of project as long as it is eligible for federal-aid funding.

GARVEE bonds, however, create some interest and issuance costs and can be more costly than GO bonds due to the higher interest rates. This could be explained by the lack of a guarantee of anticipated future federal funds that may not materialize. 


\subsubsection{Applicability of GARVEE Program in Indiana}

Indiana has used a bond program to finance transportation projects since 1990 . This program, described in Section 3.1.3, can use funds only from state and local governments for repayment of bonds. The GARVEE program provides an innovative form of bond repayment using federal-aid money.

\subsubsection{U.S.31 Corridor Improvement Project}

One of the major projects that is included in INDOT's Long Range Plan is the U.S.31 Corridor Improvement Project, which would upgrade the corridor to freeway design standards. The projected cost was estimated to be a total of \$1.2 billion in 1997 dollars if construction starts in year 2005, which includes $\$ 932$ million in construction costs and \$288 million in right-of-way-costs.

Utilizing existing INDOT resources, this project would have to wait at least until 2019. It is assumed that the U.S.31 improvements would be constructed in a five-year period between 2019 and 2024 with the complete highway opening in 2025. Bernardin, Lochmueller and Associates, Inc. [CS \& BLA, 1998] conducted an environmental impact study in 1997 for this project, and an economic analysis was completed as well, assuming the beginning of construction in 2005. A 30-year analysis period was considered for economic benefits. If the project were completed in year 2009 and opened for traffic in year 2010, it would result in total benefits to the public of $\$ 2.9$ billion for the 30 -year analysis period, as estimated by the consultants. Thus, there is a benefit-cost ratio of 2.4 that justifies the construction starting in 2005. It is likely that the project could be conducted in phases due to its size and complex nature, which might extend the construction period and lower the overall benefit-cost ratio due to increasing construction cost [CS \& BLA, 1998].

Using GARVEE financing, the project could be accelerated making it available to the public sooner, and INDOT would not have to search for additional revenue sources to fund the project as well. The issuance of GARVEE bonds would create additional debt service. As described in Section 3.1.3, INDOT may not be able to hold large additional debt burden to finance a project if its existing funds are already used up for existing debt service payments. However, GARVEE bonds for this particular project would not add 
significantly to INDOT's debt burden, as it stands now (see Section 3.1.3), because INDOT would use mostly future federal funds for repayment. There are four critical variables chosen to analyze the GARVEE impact on the economic and financial parameters of the project:

\section{Amount issued in bonds}

There are no restrictions about the amount of the bond issue under the GARVEE program. Ten different scenarios were explored in this study, where bonds could be issued for an amount equaling from 10 to 100 percent of the total project cost.

\section{Coupon interest rate}

The coupon rate determines the amount of interest that the issuer promises to pay the bondholder [Faerber, 2000]. Generally, interest rates on GARVEE bonds are close to the U.S. Treasury bond rates. However, interest rates may vary from project to project depending on project characteristics, credit rating, and other conditions. In this study the interest rates were used similar to those of U.S. Treasury bonds during September 2001.

\section{Maturity}

The maturity of a bond is the length of time until the bond comes due and the bondholder receives the par value of the bond [Faerber, 2000]. Maturity is one of the factors that influences the interest rate on a bond.

\section{Discount rate}

Discount rate reflects the time value of money and is used to discount future payments to their present value. It typically has two components: an inflation rate and a risk-adjusted return on the use of the money.

INDOT has estimated that for the U.S. 31 Corridor Improvement Project would cost $\$ 1.2$ billion. Cash is not readily available from state or federal sources and the state is not willing to issue GO bonds for the project. GARVEE bond funding, therefore, is a

good solution in this case. Based on the experience of other states, a GARVEE bond 
would most likely receive a strong, investment grade credit rating and the interest rate could be set around 4-6 percent, depending on factors such as the situation in the financial market, the credit rating of bonds, and the bond maturity. This study focused on several parameters that would indicate the economic viability of the project and would represent financial feasibility of using GARVEE technique.

\section{Annual Debt Service}

The debt service is the amount that INDOT would have to pay to investors that purchase GARVEE bonds. That amount would consist of annual interest payments plus repayment of the principal at maturity. Annual interest payment would be the coupon of the bond. It would remain the same throughout the life of the bond. As INDOT could use a part of annual federal apportionment to pay interest as well as principal, the principal amount could be evenly distributed throughout the life of the bond in annual debt service calculation. Therefore, annual debt service can be found as follows:

$$
C+P^{*} \frac{r}{(1+r)^{n}-1},
$$

where

$\mathrm{C}=$ Coupon,

$\mathrm{P}=$ Principal,

$\mathrm{r}=$ Interest Rate,

$\mathrm{n}=$ Life of Bond (Years).

Let us assume an interest rate of seven percent. If GARVEE bonds would be issued for the entire amount ( $\$ 1.2$ billion) of the project cost with the coupon rate of 5.25 percent and maturity of 25 years, the annual debt service would be

$$
5.25 \% \text { of } \$ 1200+\$ 1200 * \frac{0.07}{(1+0.07)^{25}-1}=\$ 81.97 \text { million }
$$

The annual debt service amounts for different values of interest rate and bond term are given in Table 4.2. Assuming the federal apportionment as $\$ 723$ million [INDOT, 2001a], the debt service would become nine percent of the apportionment. That 
means the annual amount of federal funds INDOT could spend on other programs would be reduced by about $\$ 66$ million. It must be remembered that with GARVEE assistance the project financing would still have to follow " $80: 20$ " percent matching requirements. Therefore, the maximum 80 percent of $\$ 1.2$ billion issued could be repaid from federal funds.

Table 4.2 U.S. 31 Annual Debt Service for \$1200 Million Bond Issuance

(in million dollars).

Year 2005

\begin{tabular}{|c|c|c|c|c|c|c|}
\hline \multirow[b]{2}{*}{$\begin{array}{c}\text { Term } \\
\text { (years) }\end{array}$} & \multirow[b]{2}{*}{$\begin{array}{l}\text { Interest } \\
\text { Rate }\end{array}$} & \multicolumn{3}{|c|}{ Annual Payment } & \multirow[b]{2}{*}{$\begin{array}{c}\text { Federal } \\
\text { Apportionment }\end{array}$} & \multirow{2}{*}{\begin{tabular}{|c|} 
Federal Share of \\
Debt Service as \% of \\
Apportionment
\end{tabular}} \\
\hline & & $\begin{array}{c}80 \% \text { Federal } \\
\text { Share }\end{array}$ & $\begin{array}{c}20 \% \text { State } \\
\text { Match }\end{array}$ & Total & & \\
\hline 10 & $4.91 \%$ & 117 & 29 & 146 & 723 & $16 \%$ \\
\hline 15 & $5.10 \%$ & 87 & 22 & 109 & 723 & $12 \%$ \\
\hline 20 & $5.10 \%$ & 72 & 18 & 90 & 723 & $10 \%$ \\
\hline 25 & $5.25 \%$ & 66 & 16 & 82 & 723 & $9 \%$ \\
\hline 30 & $5.44 \%$ & 62 & 16 & 78 & 723 & $9 \%$ \\
\hline
\end{tabular}

Since 80 percent of the debt service would be paid from federal funds, INDOT would have to find resources to cover the remaining portion. INDOT could use existing State Highway and Road Construction and Improvement Fund (SHRCIF) and the Crossroads 2000 Fund for partial GARVEE bond repayment, as these funds are also used to pay annual debt service on bonds issued by ITFA (see Section 3.1.3).

If INDOT were to reduce the amount issued in bonds, the annual debt service for repayment would reduce as well. If GARVEE bonds were issued for 80 percent or less of the total project costs, the entire debt service could be repaid from federal reimbursements. In this case, project financing would still follow the "80:20 percent" matching requirements, as only the federal share would be issued in GARVEE bonds. For example, if INDOT would issue bonds for half of the total amount (\$600 million), then the total annual debt service payment, with 25 years maturity paying an interest rate of 5.25 percent, would be six percent of the annual federal apportionment in 2005 (Table 4.3). 
Table 4.3 U.S 31 Annual Debt Service for \$600 Million Bond Issuance.

Year 2005
\begin{tabular}{|c|c|c|c|c|}
\hline $\begin{array}{c}\text { Term } \\
\text { (years) }\end{array}$ & Interest Rate & $\begin{array}{c}\text { Annual Payment } \\
(\$ \text { million })\end{array}$ & $\begin{array}{c}\text { Federal } \\
\text { Apportionment } \\
(\$ \text { million })\end{array}$ & $\begin{array}{c}\text { Debt as \% of } \\
\text { Apportionment }\end{array}$ \\
\hline 10 & $4.91 \%$ & 73 & 723 & $10 \%$ \\
\hline 15 & $5.10 \%$ & 54 & 723 & $8 \%$ \\
\hline 20 & $5.10 \%$ & 45 & 723 & $6 \%$ \\
\hline 25 & $5.25 \%$ & 41 & 723 & $6 \%$ \\
\hline 30 & $5.44 \%$ & 39 & 723 & $5 \%$ \\
\hline
\end{tabular}

Analyzing different scenarios, INDOT would have to decide what percent of annual federal apportionment it is willing to take away from other programs. According to the experience of other states, 11 percent could be used as an acceptable level for debt service of annual federal apportionment. By choosing a different coupon rate and maturity, we can observe the possible percentage of total project cost that could be issued in GARVEE bonds. Figure 4.4 shows an example of such analysis. The result allows us to choose the scenario that would not exceed a chosen acceptable level for debt service of annual federal apportionment. Critical variables (interest rates, maturity, and amount issued) were chosen as in Tables 4.2 and 4.3. 


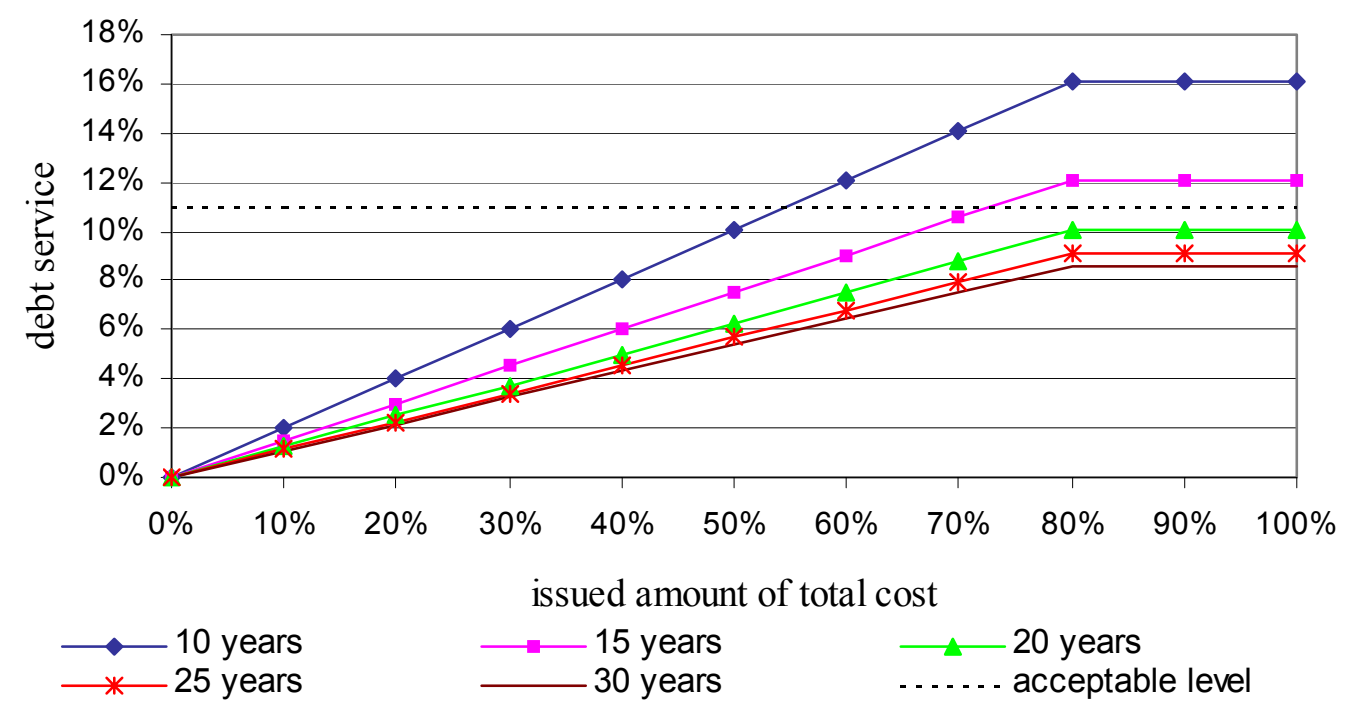

Figure 4.4 U.S 31 Annual Debt Service in Percents of Federal Apportionment in 2005 for Different Maturity Bonds.

For a given amount issued, the annual debt service varies depending on the term of the bond life cycle and interest rates. The greater the amount issued, the greater is the annual debt service. Also, the annual debt service decreases with the increasing bond life. Note that the maximum percentage of federal apportionment that INDOT can receive for GARVEE bond repayment is reached when 80 percent of the total project cost is issued in bonds (Figure 4.4), according to the "80:20" matching requirement.

\section{Net Present Value}

One of the indicators used to evaluate the economic viability of an individual financing transaction is Net Present Value (NPV). It reflects the present value (PV) of future cash flows, both positive and negative. Looking at GARVEE bond issuance as a financing transaction, the NPV can be found as follows [Ross, 1999]:

$$
N P V_{\text {GARVEE }}=P V \text { of Amount Issued }-P V \text { of }(\text { Interest }+ \text { Face Value })
$$


If the NPV were positive, INDOT would obtain subsidized financing, applying the GARVEE program. For the U.S. 31 project, NPV calculations were done for different scenarios by changing the amount issued, the maturity, and the interest rate (Figure 4.5). The discount rate assumed was seven percent. Whenever the coupon rate is less than the discount rate, the bond issuance is favorable, as the NPV is greater then zero.

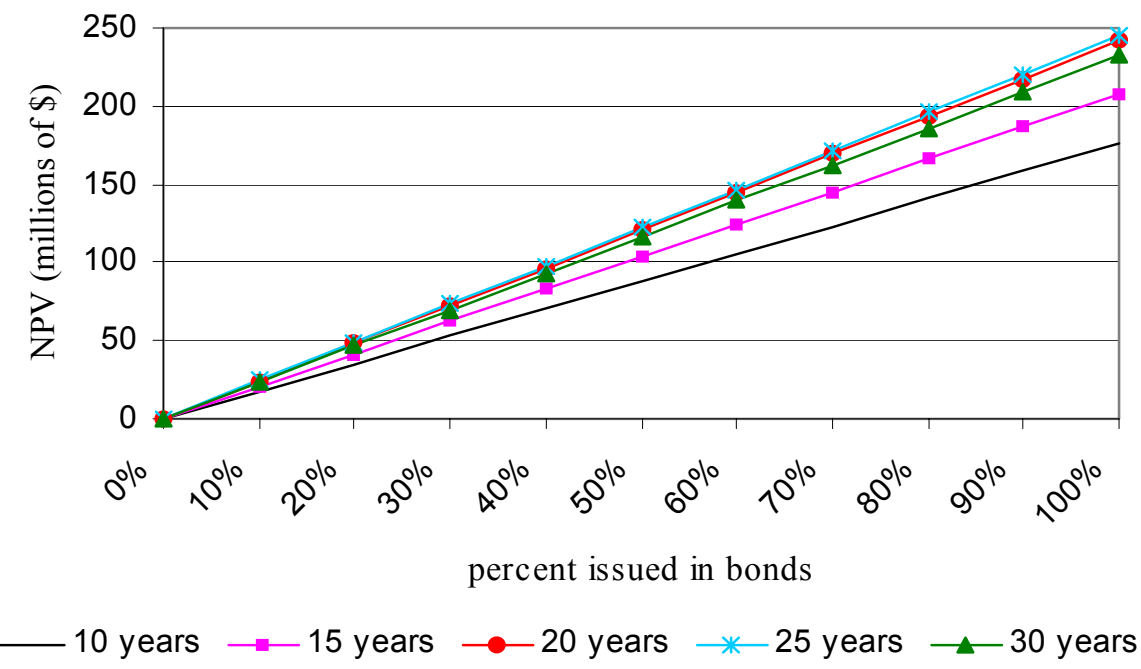

Figure 4.5 U.S 31 NPV of GARVEE Financing Transaction (Discount Rate 7\%).

If the discount rate is less then the coupon rate of a bond, the NPV becomes negative, as shown in Figure 4.6, for a case with discount rate of three percent. The greater the difference between the discount rate and the coupon rate, the more the NPV moves away from zero. If the discount rate is equal to the coupon rate, the agency neither benefits, nor incurs losses by issuing bonds (NPV=0). 


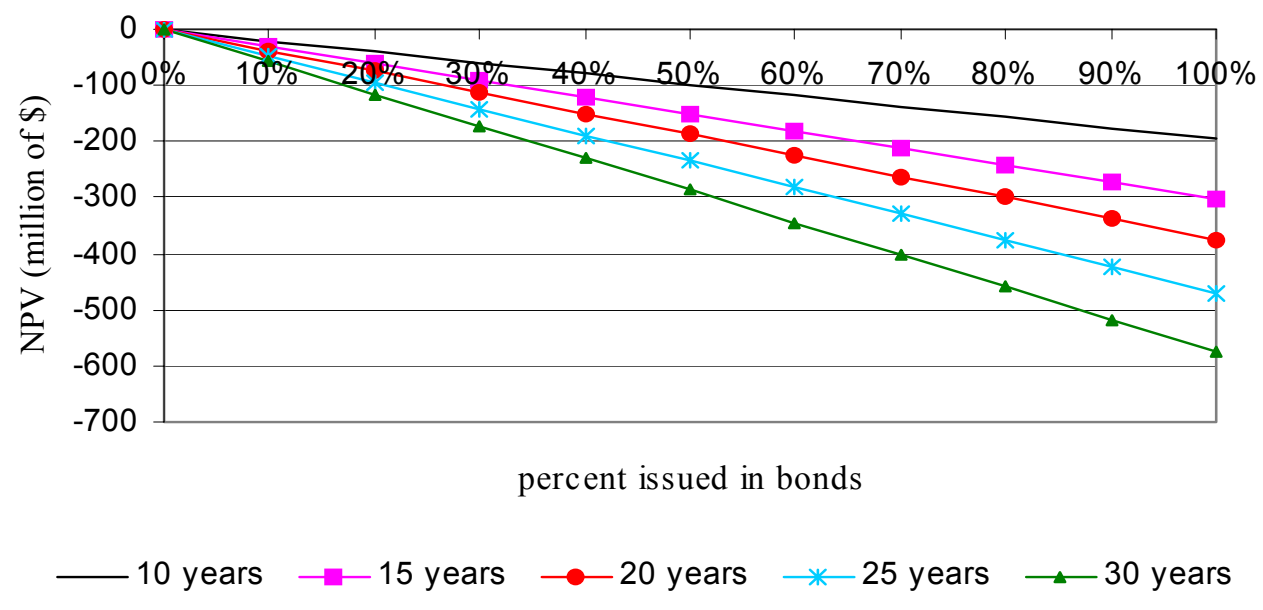

Figure 4.6 U.S. 31 NPV of GARVEE Financing Transaction (Discount Rate 3\%).

Sensitivity analysis allows us to determine also how sensitive the NPV of the entire project is to changes of underlying assumptions. The NPV of a project is the difference between the present value of the benefit stream and the present value of the cost stream for the project. Using GARVEE as the financing method for the U.S. 31 project, the NPV can be found as follows:

$$
\begin{aligned}
N P V_{\text {PROJECT }}= & \text { PV of Benefits }+ \text { PV of Amount Issued }- \text { PV of Remaining Project Cost }- \\
& -P V \text { of }(\text { Interest }+ \text { Face Value })
\end{aligned}
$$

where $\quad$ Remaining Project Cost $=$ Total Project Cost - Amount Issued . 
If the NPV of the project is greater than zero, the GARVEE financing is acceptable. Applying sensitivity analysis we can observe the GARVEE impact on the project's NPV and the extent to which the project NPV changes for different values of the critical variables. Figure 4.7 illustrates the GARVEE impact on the NPV of the project.

a) discount rate $3 \%$

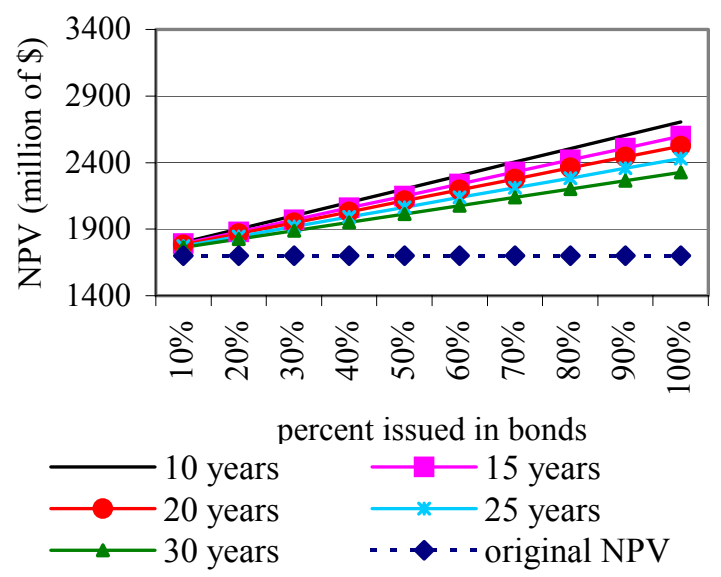

a) discount rate $7 \%$

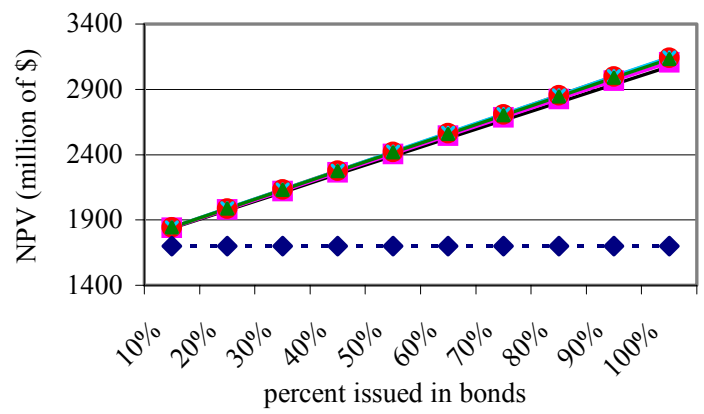

Figure 4.7 U.S. 31 NPV with Respect to Different Values of Interest Rate, Maturity and Amount Issued in GARVEE Bonds.

Figure 4.7 shows an example of changes in the NPV when different discount rates are applied to the same scenario. The greater the amount of the bond issue, the greater is the NPV of the project, which can be explained by looking at the analysis of the NPV of the GARVEE financing transaction in Figures 3.5 and 3.6.

In none of the cases do the NPV of the GARVEE financing transaction exceed the estimated present worth of cost of the project without GARVEE financing ( $\$ 1.2$ billion). Given the known values of critical variables, it is less expensive to borrow the money than to spend the existing funds. The analysis showed that with any given variables the NPV of the project with the GARVEE funding is greater than the estimated NPV (original NPV of \$1.7 billion) without GARVEE assistance [CS \& BLA, 1998]. 


\section{Benefits vs. Debt Service}

To justify the use of the GARVEE program for the U.S. 31 Corridor Improvement Project, observing the economic benefits of project acceleration is helpful. Bernardin, Lochmueller \& Associates [CS \& BLA, 1998] estimated in their study that the U.S. 31 Corridor Improvement Project would result in $\$ 2.9$ billion in total benefits over the 30year analysis period. The total benefit of starting this project in 2005 would be greater than if the project started in 2019 due to the fact that the savings for road users occurring later would be discounted in proportion to the length of the delay. The economic analysis of the project showed that the project would generate 2.4 times as much benefit as it cost if started in year 2005 [CS \& BLA, 1998]. To illustrate the value of project acceleration, let us use the benefit-cost ratio as a multiplier in order to find discounted marginal benefits due to acceleration of the project, using the following formula [FHWA, 1997a]:

$$
\text { Discounted Benefits }=\frac{C^{*} I}{(1+r)^{n}},
$$

where

$\mathrm{C}=$ Project Cost,

$\mathrm{I}=$ Benefit-Cost Ratio,

$\mathrm{r}=$ Discount Rate,

$\mathrm{n}=$ Number of Years of Project Delay.

The expected benefits to be discounted for various periods of deferment of the project are shown in Figure 4.8. For example, if the project is initiated in 2005 and completed in 2009, the present worth of benefits in 2005 would be $\$ 2.9$ billion. However, if the project construction would start in 2020 , the present worth of benefits would be $\$ 1$ billion. 


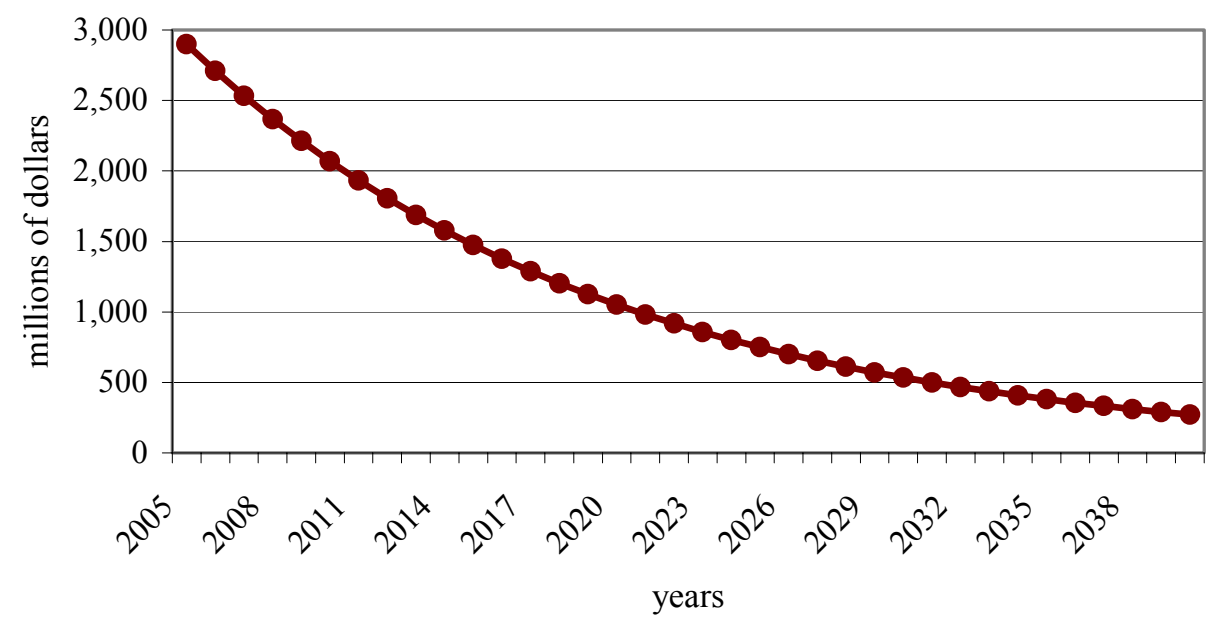

Figure 4.8 U.S. 31 Present Worth of Benefits in 2005.

The discount rate for all computations was assumed to be seven percent, as used by the consultants [CS \& BLA. 1998] in the economic analysis of the project. The discounted stream of benefits realized from the project started in 2005 exceeds that of the same project started later. If the project were started in 2019, as planned by INDOT, its benefits would decrease from $\$ 2.9$ billion in 2005 to $\$ 1.1$ billion in 2019. Accelerating the project by 14 years can be viewed as yielding a $\$ 1.8$ billion increase in marginal benefits.

Another way to evaluate GARVEE assistance could be to look at the change in user benefits vs. the change in debt service due to the project's acceleration. Sensitivity analysis was performed in Microsoft Excel, applying different values for the critical variables mentioned above to observe the change in present worth (PW) of total debt service over the bond life cycle vs. the decrease of discounted benefits over time. Results of such an analysis are shown in Figure 4.9. It demonstrates the PW in 2005 of total debt service resulting from bond issuance in various years, along with the PW of benefits as in Figure 4.8. The amount of the GARVEE bonds issued has been assumed as a percentage (from 10 to 100 percent) of the total project cost. 


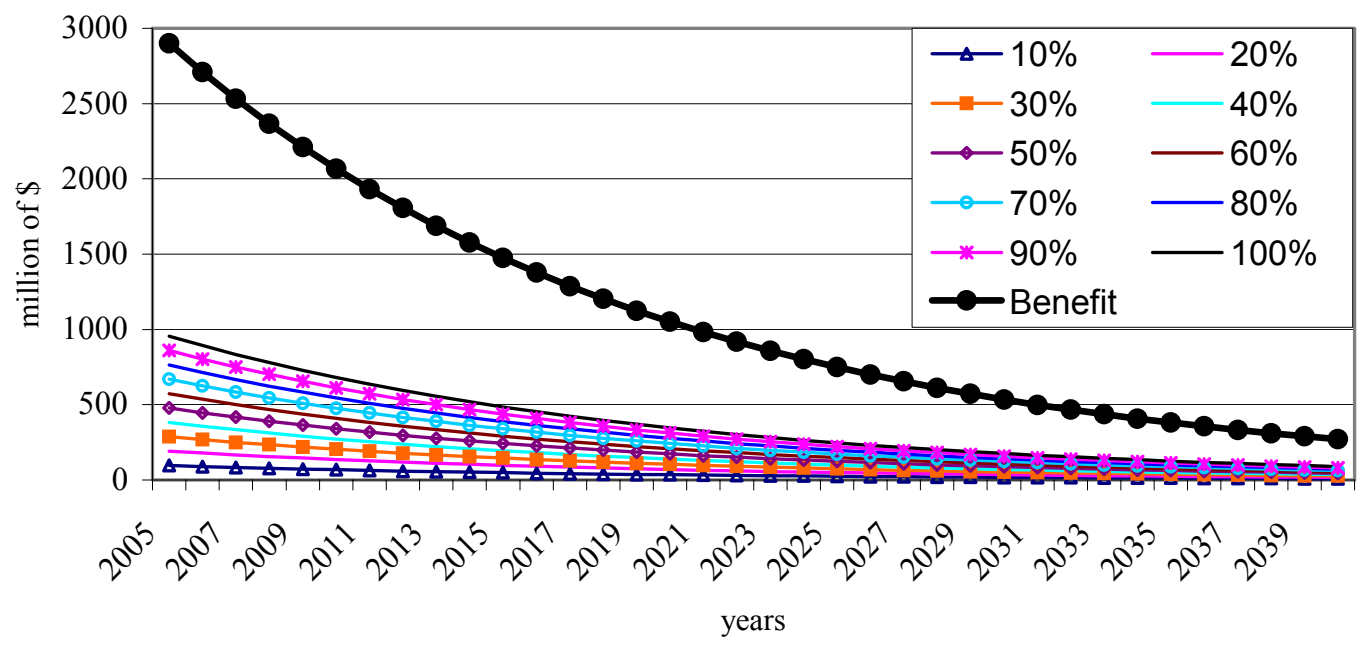

Figure 4.9 U.S 31 Present Worth of Benefits and Total Debt Service in 2005.

Figure 4.9 represents the scenario when the maturity of the bond is assumed to be 25 years, the interest rate 5.25 percent and the discount rate seven percent. The amount to be issued was determined as a percentage (from 10 percent to 100 percent) of the total project cost. Total debt service (D) was calculated using following equation

$$
D=A * \frac{(1+r)^{n}-1}{r(1+r)^{n}}+\frac{F}{(1+r)^{n}},
$$

where

A = Annual Interest Payment,

$\mathrm{r}=$ Interest Rate,

$\mathrm{n}=$ Bond Maturity Period,

$\mathrm{F}=$ Face Value.

As shown in Figure 4.9, the debt service continues to decrease over time. If we look only at the debt service curves, it appears that it is not beneficial to do the project sooner. However, debt service must be analyzed concurrently with the stream of benefit, as discounted benefits decrease at a higher rate than the debt service generated from bond 
issuance. Debt service includes the face value of bonds as well as the annual interest. Interest forms a significant portion of the total debt service and slows the decrease of PW of debt service over time, compared with the discounted benefit stream. Therefore, it is not beneficial to wait for a lower debt service while losing much more in user savings.

In the analysis shown in Figure 4.9, the amount issued in bonds was determined as a percentage of the total cost that was assumed constant over time, eliminating inflation or any other factors that might affect it. However, to make a more realistic analysis, the inflation cost occurring with the project costs over time need to be considered. The composite price index for federal-aid highway construction provided by FHWA has been deemed as an accurate measure of inflation for the economic analysis of transportation projects. This index has been calculated annually for each state, based on information submitted for federal-aid construction costs over $\$ 500,000$ [FHWA, 1997b]. The composite index for each state measures the change in that state's index since the base year of 1987. This allows us to find the average yearly inflation rate of 3 percent for federal-aid construction costs in Indiana, during the time period from 1997 to 2000 [FHWA, 1997b, 1998, 1999a, 2000].

Incorporating inflation cost into the calculation of the PW of debt service increases the value of debt service as the amount issued increases over time (Figure 4.10). The avoidance of cost increases due to inflation is another financial advantage for executing the project sooner. 
a) discount rate $7 \%$

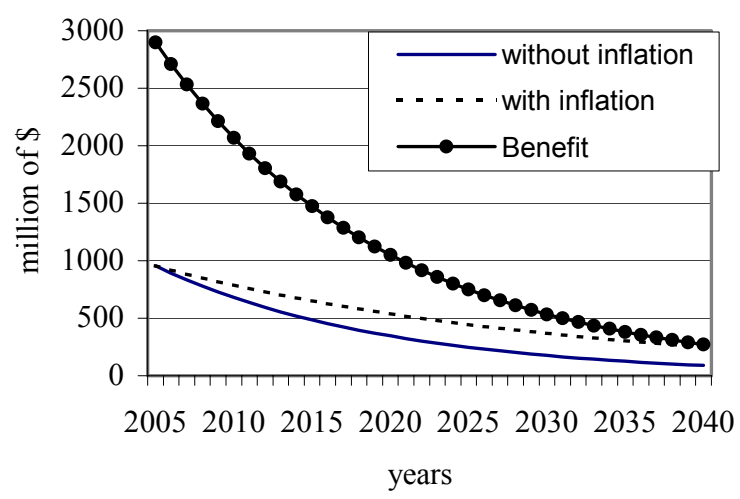

b) discount rate $4 \%$

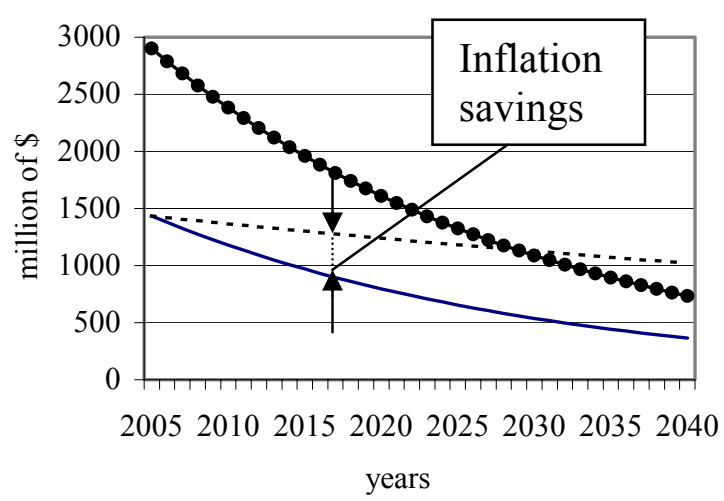

Figure 4.10 U.S 31 Discounted Benefits and PW of Debt Service in 2005 with Incorporated Inflation Factor.

The results show that it is feasible to use the GARVEE program as a financing technique for U.S. 31, as it is flexible in its application and, even with the additional cost of bond issuance, the benefits reach the users sooner than otherwise possible and saves the agency future costs related to delaying the project. Therefore, even though GARVEE financing might be more expensive, comparing annual debt service payments with the original project cost, it allows INDOT to arrange construction financing all at once and realize project benefits sooner.

\subsubsection{SR 641 (Terre Haute Bypass)}

Another project included in INDOT's planning horizon is SR 641 (Terre Haute Bypass). SR 641 is scheduled for completion in relatively short order, but changing economic conditions have the potential to affect the project's timeline. "Construction of this project is considered necessary to provide a bypass to Terre Haute and the extensive traffic congestion on U.S. 41 in southern Terre Haute [Federal Register, 1996].”

The project is planned for three phases. Phase I, planned for 2003, will create an access road to allow Phases II and III to continue. It is estimated that construction of Phase I will cost approximately $\$ 13$ Million. Currently construction of Phase II is scheduled to begin in 2004. This portion of the project consists of constructing the south half of the mainline at an estimated cost of \$17 Million. Finally, Phase III, scheduled to begin construction in 2005, will include the north half of the mainline. Phase III is estimated to cost $\$ 42$ Million. The total cost of construction of the three phases is 
estimated at $\$ 72$ Million. Each of the above cost figures is given in the year the phase is scheduled for construction. In addition to a construction cost of $\$ 72$ Million, the project will incur right-of-way acquisition cost of approximately $\$ 4.5$ Million and design fees of $\$ 2$ to $\$ 3$ Million for a total project cost of $\$ 79$ Million [Hazeltine, 2002]. Currently SR 641 is progressing on schedule, but for the purpose of illustrating GARVEE bond financing, it will be assumed that the current economic decline may force INDOT to delay the project for 10 years.

In January 1995, INDOT completed the Engineer's Report for the SR 641. Appendix $\mathrm{C}$ of the Engineer's Report details the decision analysis conducted by INDOT engineers in approving the project and in selecting a route for the new road. The overall goal of the assessment was to maximize the route's cost effectiveness while minimizing monetary and external negative impacts [INDOT, 1995]. The assessment rates each alternative with an overall score calculated as a function of 34 weighted criteria such as the following:

- Number of acres of impacted woodlands

- Number of acres of impacted wetlands

- Number of residential relocations

- Residential noise impact

- Potential for economic growth and development

- Construction and right-of-way cost

- Compatibility with local long-range plan

In addition to the 1995 report, a December 1990 Preliminary Feasibility Study concluded that construction of SR 641 is a worthwhile project. For the purpose of illustrating GARVEE bond financing we will assume SR 641 has a benefit cost ratio of 2.0. The project's potential to relieve congestion on U.S. 41 and potential economic development surrounding the new road justify this ratio. To ensure viable results from the GARVEE bond financing analysis, a sensitivity analysis of the benefit- cost ratio will be conducted in the range between 1.0 and 3.0. 
INDOT could use GARVEE bonds to fund the project. Using GARVEE bonds would allow SR 641 to stay on schedule and deliver the benefits of the project much sooner. Both of these goals could be reached without significantly impacting INDOT's debt burden.

\section{Amount issued in bonds}

As explained in the U.S. 31 Corridor Improvement Project example, there are no restrictions limiting the percentage of the project's cost that can be borrowed using GARVEE bonds. In this case study 10 different scenarios will be explored between 10 and 100 percent of the project's cost.

\section{Coupon interest rate}

For this case study interest rates similar to those available for U.S. Treasury bonds during March 2002 will be used. This follows the precedent explained in the analysis of the U.S. 31 Corridor Improvement Project.

\section{Maturity}

This analysis will consider bonds with maturities in the range between 10 and 30 years.

\section{Discount rate}

Current plans for SR 641 call for partial federal funding; therefore, GARVEE bonds issued for this project could be serviced in part by Indiana's federal apportionment. As with the U.S. 31 Corridor Improvement Project, experience of other states shows that GARVEE bonds would most likely receive a strong, investment grade credit rating and the interest rate could be set around 4-6 percent, depending on factors such as the situation in the financial market, the credit rating of bonds, and the bond maturity. A sensitivity analysis of using several discount rates in the range of 3 to 9 percent will be conducted for SR 641 to ensure the economic viability of debt financing. 


\section{Annual Debt Service}

The method previously illustrated in the GARVEE analysis of U.S. 31 will be used here to calculate the annual debt service for SR 641. Assuming an interest rate of eight percent, if GARVEE bonds are issued for the entire amount needed to fund SR 641 (\$79 Million) with a coupon rate of 4.875 percent and maturity of 10 years, the annual debt service will be

$$
4.875 \% \text { of } \$ 79+\$ 79 * \frac{0.08}{(1+0.08)^{10}-1}=9.30 \text { million }
$$

The annual debt service amounts for different values of interest rate and bond term are given in Table 4.4. Assuming the federal apportionment as $\$ 723$ million [INDOT, 2001a], the federal portion of the debt service would become approximately one percent of the federal apportionment. That means the annual amount of federal funds INDOT could spend on other programs would be reduced by about $\$ 7.4$ million. It must be remembered that with GARVEE assistance, the project financing would still have to follow " $80: 20$ " percent matching requirements. Therefore, a maximum of 80 percent of the debt service generated by the $\$ 79$ million bond issue could be repaid from federal funds. Since 80 percent of the debt service would be paid from federal funds, INDOT would have to find resources to cover the remaining portion. 
Table 4.4 SR 641 Annual Debt Service for \$79 Million Bond Issuance

(in million dollars).

Year 2003

\begin{tabular}{|c|c|c|c|c|c|c|}
\hline \multirow[b]{2}{*}{$\begin{array}{r}\text { Term } \\
\text { (years) }\end{array}$} & \multirow[b]{2}{*}{$\begin{array}{l}\text { Interest } \\
\text { Rate }\end{array}$} & \multicolumn{3}{|c|}{ Annual Payment } & \multirow[b]{2}{*}{$\begin{array}{c}\text { Federal } \\
\text { Apportionment }\end{array}$} & \multirow{2}{*}{\begin{tabular}{|c|} 
Federal Share of \\
Debt Service as \% of \\
Apportionment \\
\end{tabular}} \\
\hline & & $\begin{array}{c}80 \% \text { Federal } \\
\text { Share }\end{array}$ & $\begin{array}{c}20 \% \text { State } \\
\text { Match }\end{array}$ & Total & & \\
\hline 10 & $4.875 \%$ & 7.4 & 1.9 & 9.3 & 723 & $1.0 \%$ \\
\hline 15 & $5.000 \%$ & 5.5 & 1.4 & 6.9 & 723 & $0.8 \%$ \\
\hline 20 & $5.125 \%$ & 4.6 & 1.2 & 5.8 & 723 & $0.6 \%$ \\
\hline 25 & $5.250 \%$ & 4.2 & 1.0 & 5.2 & 723 & $0.6 \%$ \\
\hline 30 & $5.375 \%$ & 4.0 & 1.0 & 4.9 & 723 & $0.5 \%$ \\
\hline
\end{tabular}

If INDOT were to reduce the amount issued in bonds, the annual debt service for repayment would be reduced as well. For example, if INDOT had $20 \%$ of the cost of the project immediately available from non-federal sources, then the remaining eighty percent issued in GARVEE bonds could be repaid wholly with Indiana's federal apportionment. This solution would still follow the "80:20 percent" matching requirements, as only the federal share would be issued in GARVEE bonds.

The magnitude of the projects and maturity of bonds INDOT chooses will be a function of the total percentage of the federal apportionment allocated toward debt service. Figure 4.11 shows the portion of the federal apportionment demanded by SR 641 under different maturities. Critical variables (interest rates, maturity, and amount issued) were chosen as in Table 4.4. 


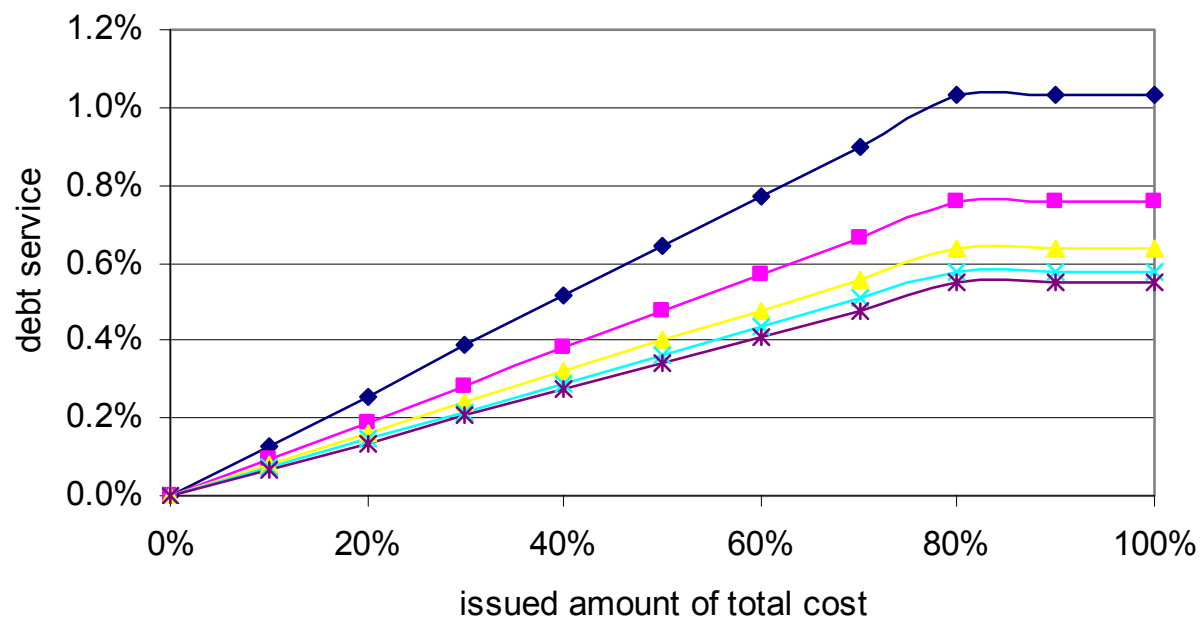

$\multimap 10$ years $\rightarrow-15$ years $\triangle 20$ years $\leftarrow 25$ years $\rightarrow 30$ years

Figure 4.11 SR 641 Annual Debt Service in Percents of Federal Apportionment in 2003 for Different Maturity Bonds.

Figure 4.11 illustrates that SR 641 could be financed using GARVEE bonds with minimal impact on funds remaining from the federal apportionment for other projects. More importantly, we see the same trends here as we did in the analysis of U.S. 31. The greater the amount issued, the greater is the annual debt service. Also, the annual debt service decreases with the increasing bond life. As with U.S. 31, when 80 percent of the project's cost is reached, the graph becomes flat because the maximum percentage of federal apportionment that INDOT can receive for GARVEE bond repayment is reached according to the " $80: 20$ " matching requirement.

\section{Net Present Value}

The NPV of financing SR 641 through GARVEE bonds was calculated using the methodology outlined in the analysis of U.S. 31. NPV calculations of financing were completed for different scenarios by changing the percentage of the project cost issued as debt and the maturity of the bonds. Figure 4.12 shows the NPV of financing the project assuming an interest rate of eight percent. 


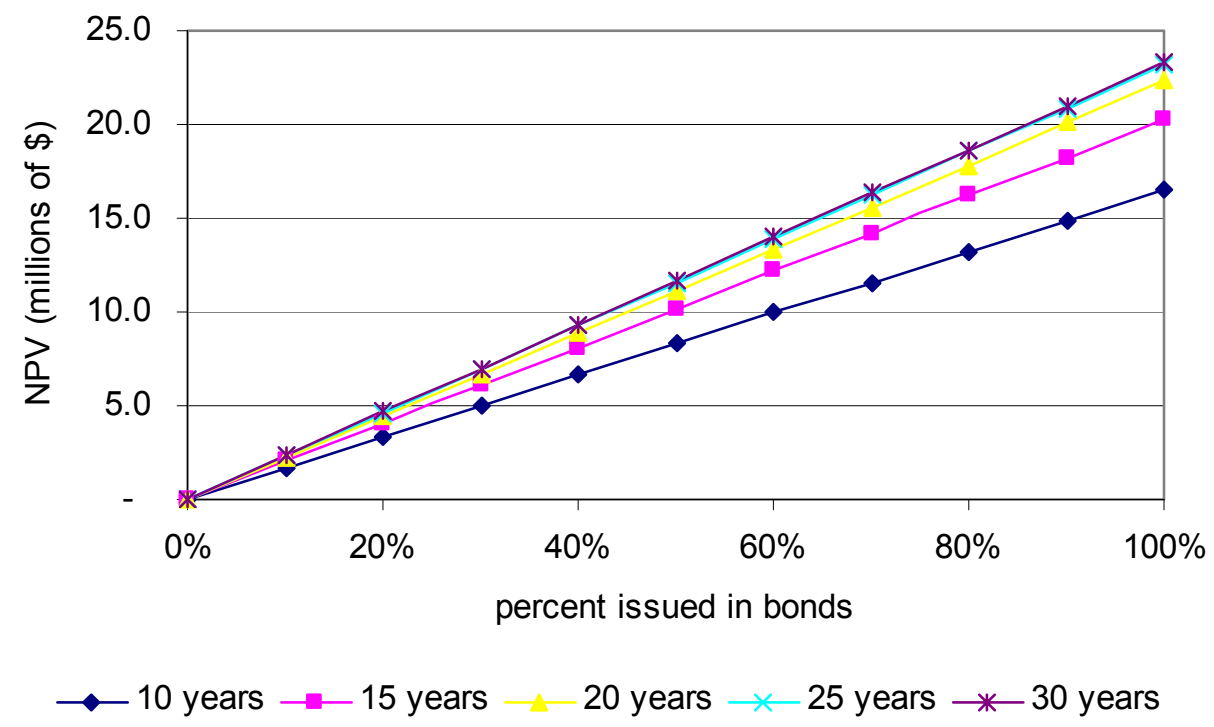

Figure 4.12 SR 641 NPV of GARVEE Financing Transaction (Discount Rate 8\%).

Figure 4.12 illustrating the NPV of financing of SR 641 displays similar results as found in the analyses of U.S. 31. First, the NPV of financing the project increases linearly as a function of the percentage of project cost. Second, as the maturity of the bonds increase, the value gained from choosing a longer maturity bond diminishes. This result is a function of the corresponding increase in the number of debts service payments over the period of the loan.

Figure 4.12 indicates that the NPV of financing SR 641 with GARVEE bonds is always positive regardless of the maturity. From this comes an important question. What would make the NPV of financing the project negative? To answer this question a sensitivity analysis to determine the effect of discount rates on the NPV of GARVEE bond financing of SR 641 was conducted. Interest rates between 3 and 9 percent were tested. Figure 4.13 illustrates typical results assuming $100 \%$ of the project is financed with GARVEE bonds. 


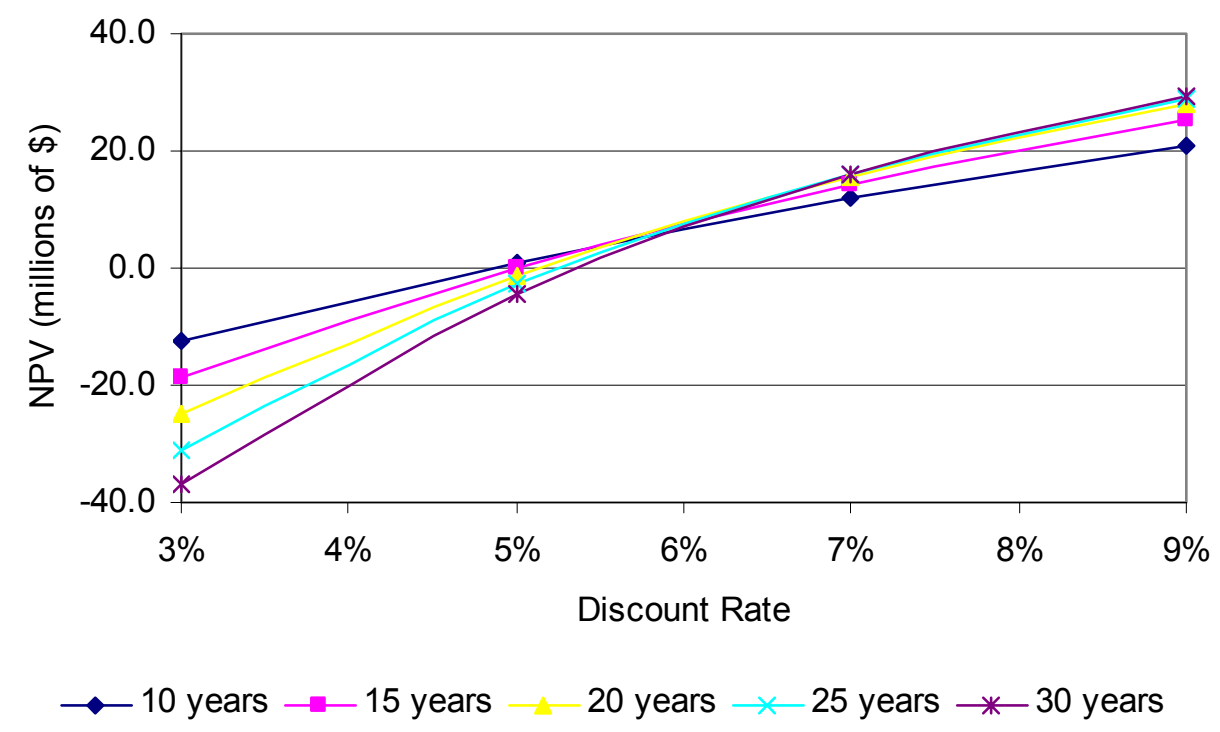

Figure 4.13 SR 641 NPV of GARVEE Financing Transaction (100\% Project Financing).

Figure 4.13 illustrates two important trends. First, the NPV of financing SR 641 increases as the discount rate increases. Second, the point at which each maturity crosses the $\mathrm{X}$-axis (representing the point at which the financing transaction switches from -NPV to $+\mathrm{NPV}$ ) is different. Why? Because the coupon rate for each maturity differs. As discussed in the U.S. 31 case study, when the discount rate is less then the coupon rate of a bond, the NPV of financing the project becomes negative. The greater the difference between the discount rate and the coupon rate, the more the NPV moves away from zero. If the discount rate is equal to the coupon rate, the agency neither benefits, nor incurs losses by issuing bonds (NPV $=0$ ).

The preceding section investigates the financing aspects of an NPV analysis for SR 641. To understand the full benefits of GARVEE bond financing for this project requires an analysis of the full NPV of the project under GARVEE bond financing. It will be assumed that regardless of the percent of project cost chosen for financing and the bond maturity the project time line will not change.

As explained in the analysis of U.S. 31, the NPV of a project is the difference between the present value of the benefit stream and the present value of the cost stream for the project. Using GARVEE bonds as the financing method for SR 641, the NPV can be found using the following equation explained in the analysis of U.S. 31 : 


$$
\begin{aligned}
\text { NPV PROJECT }= & \text { PV of Benefits }+ \text { PV of Amount Issued }- \text { PV of Remaining Project Cost }- \\
& - \text { PV of (Interest }+ \text { Face Value }),
\end{aligned}
$$

If the NPV of the project is greater than zero, the project is acceptable. By applying sensitivity analysis to the discount rate, bond maturity and percentage of project cost financed we can observe the impact GARVEE bond financing has on the project's NPV. The four graphs in Figure 4.14 illustrate the impact of using GARVEE bonds as a

\begin{tabular}{|c|c|c|}
\hline$\bullet 10$ years & $\rightarrow-15$ years & 20 years \\
\hline-25 years & * 30 years & $\begin{array}{c}\text { Without Bond } \\
\text { Financing }\end{array}$ \\
\hline
\end{tabular}
financing tool on the NPV of the SR 641 over a wide range of discount rates.

a) discount rate $=3 \%$

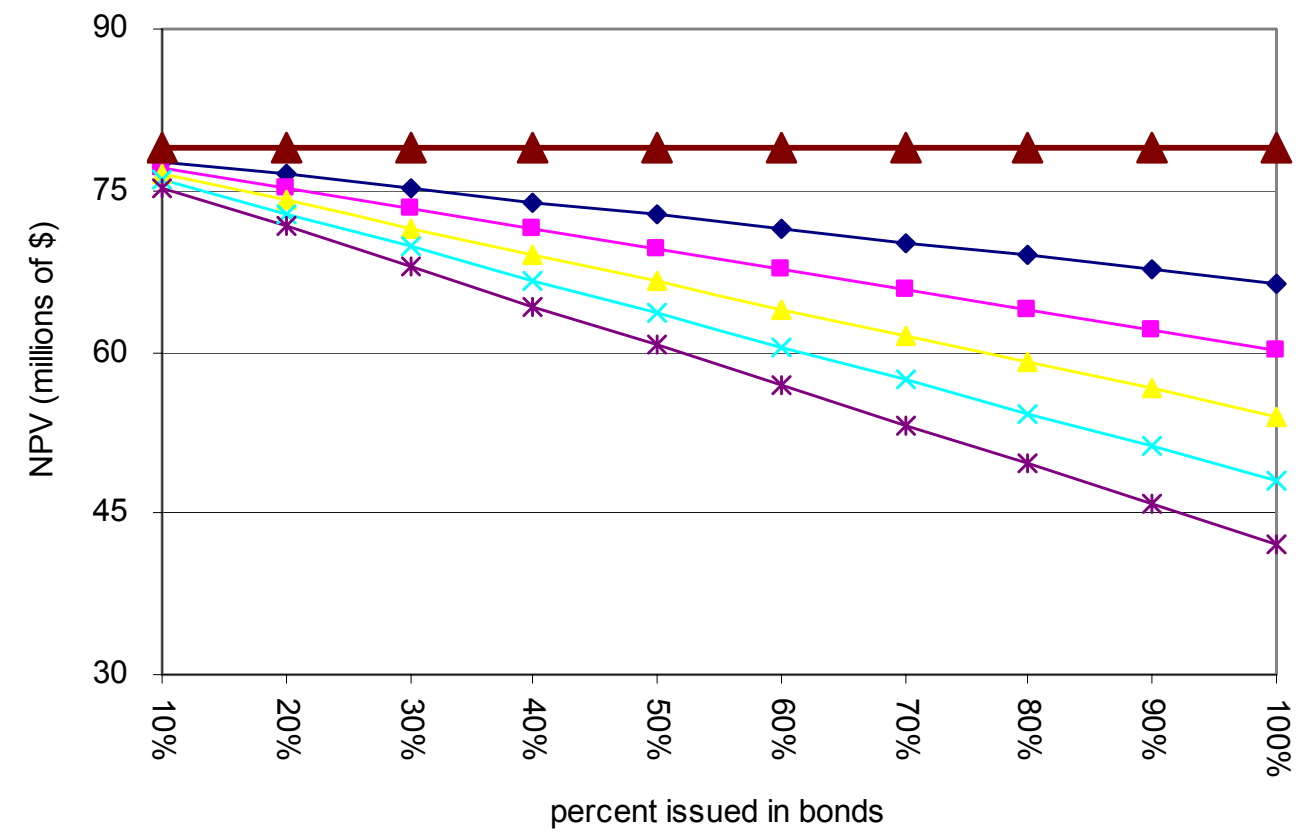


b) discount rate $=5 \%$

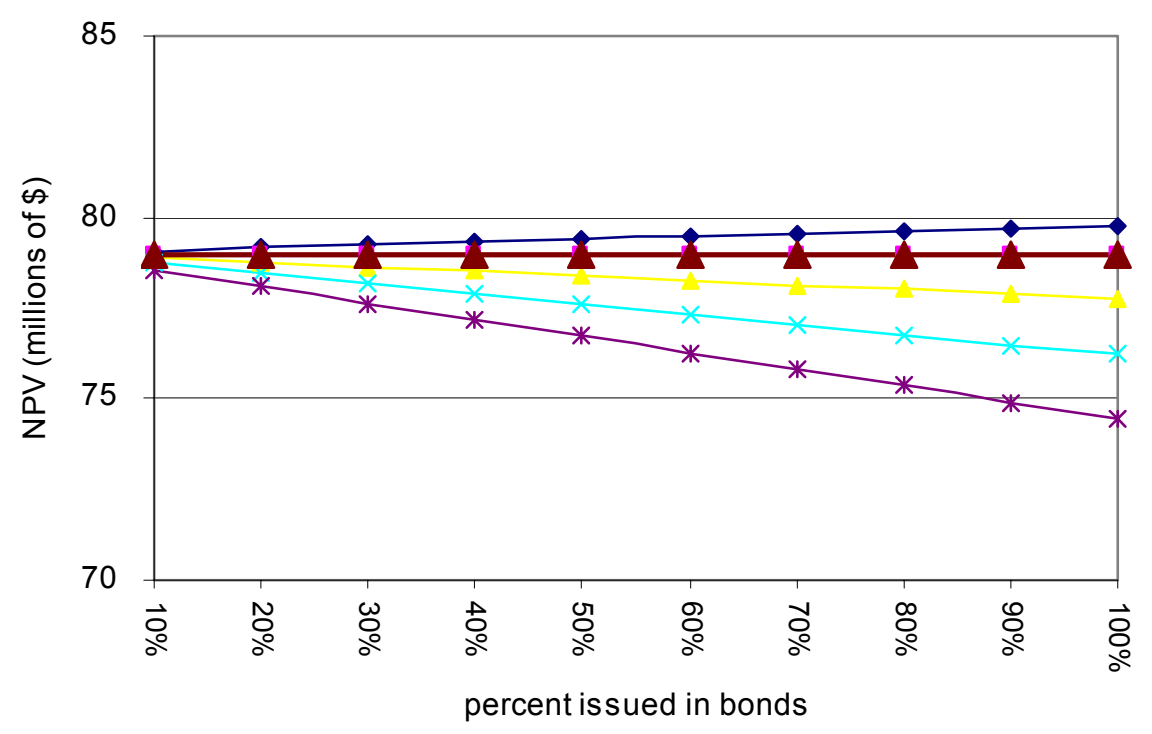

c) discount rate $=7 \%$

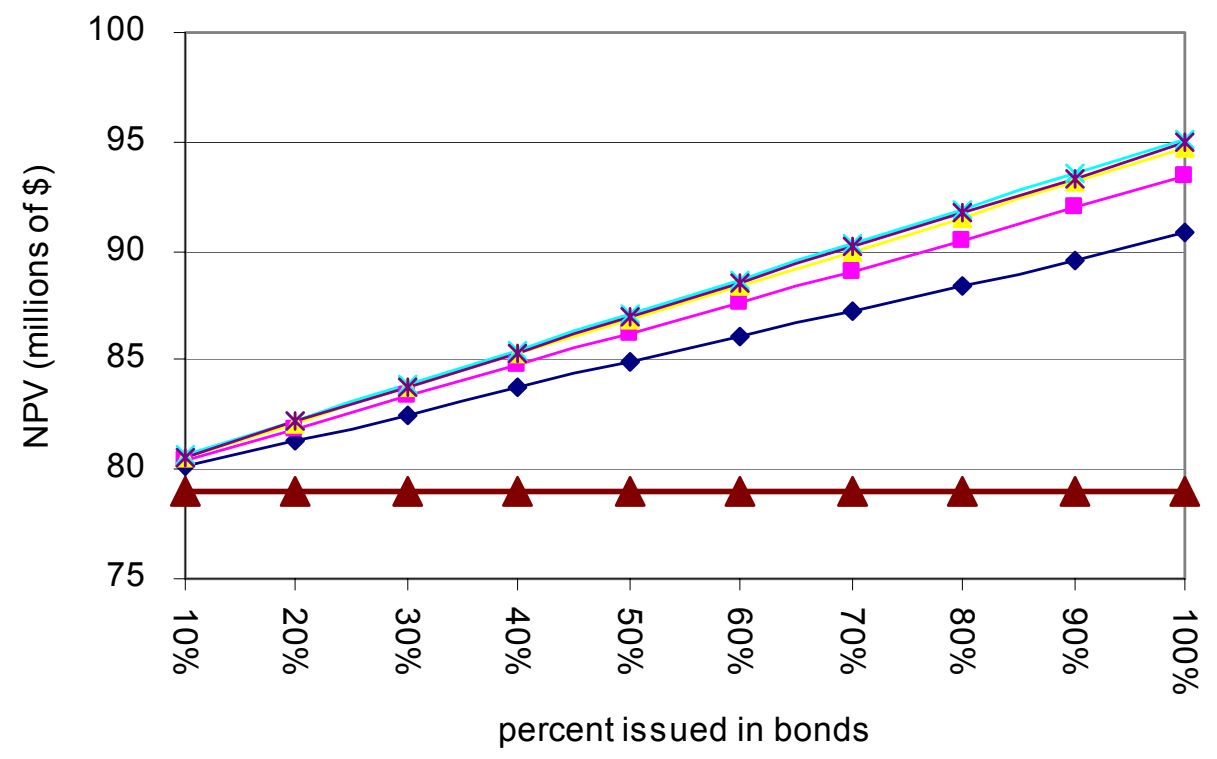


d) discount rate $=9 \%$

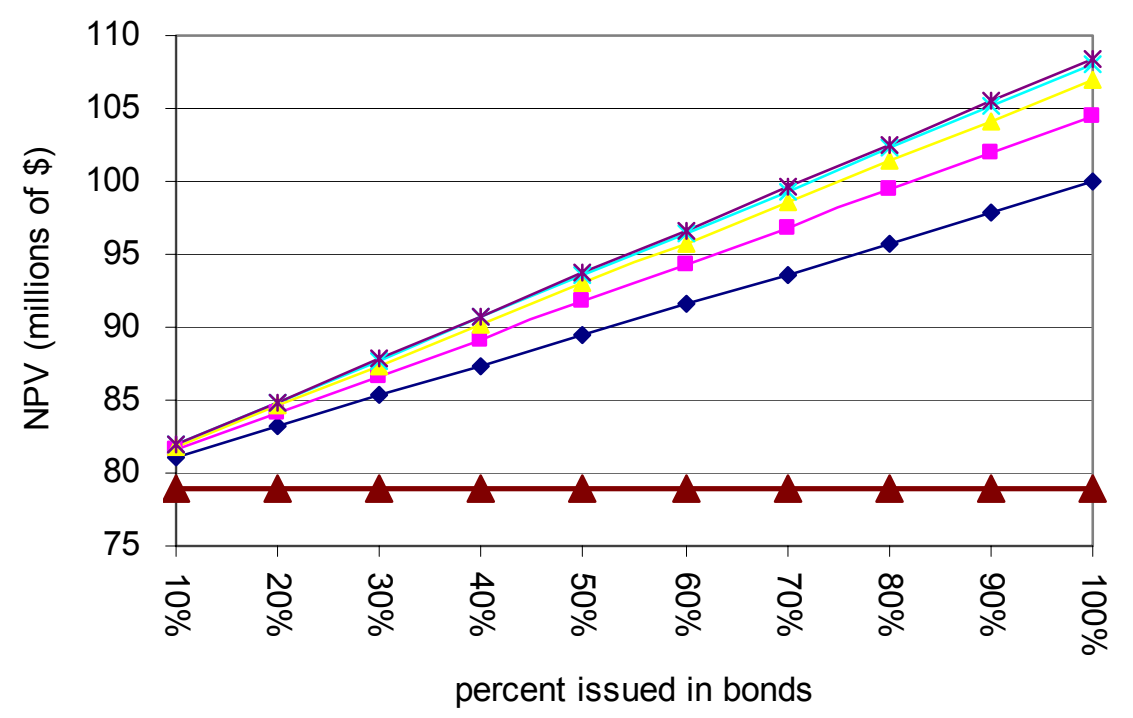

Figure 4.14 SR 641 NPV with Respect to Different Values of Interest Rate, Maturity and Amount Issued in GARVEE Bonds.

The following valuable lessons can be learned by observing the trends present in Figure 4.14:

- As the discount rate increases the optimal bond maturity to maximize NPV switches from a shorter period to a longer period.

- Most importantly, the NPV of the project is always higher with GARVEE bond financing than without when the discount rate is higher than the coupon rate for a bond.

Up to this point the analysis has assumed a benefit cost ratio of 2.0. Since 2.0 is an assumed value based on available information, it is important to consider what the NPV of the project will be under varying benefit-cost ratios. To determine trends associated with different benefit-cost ratios a sensitivity analysis was conducted. Figure 4.15 illustrates these trends assuming 100\% project financing and an eight percent discount rate with benefit cost ratios between 1.0 and 3.0. 


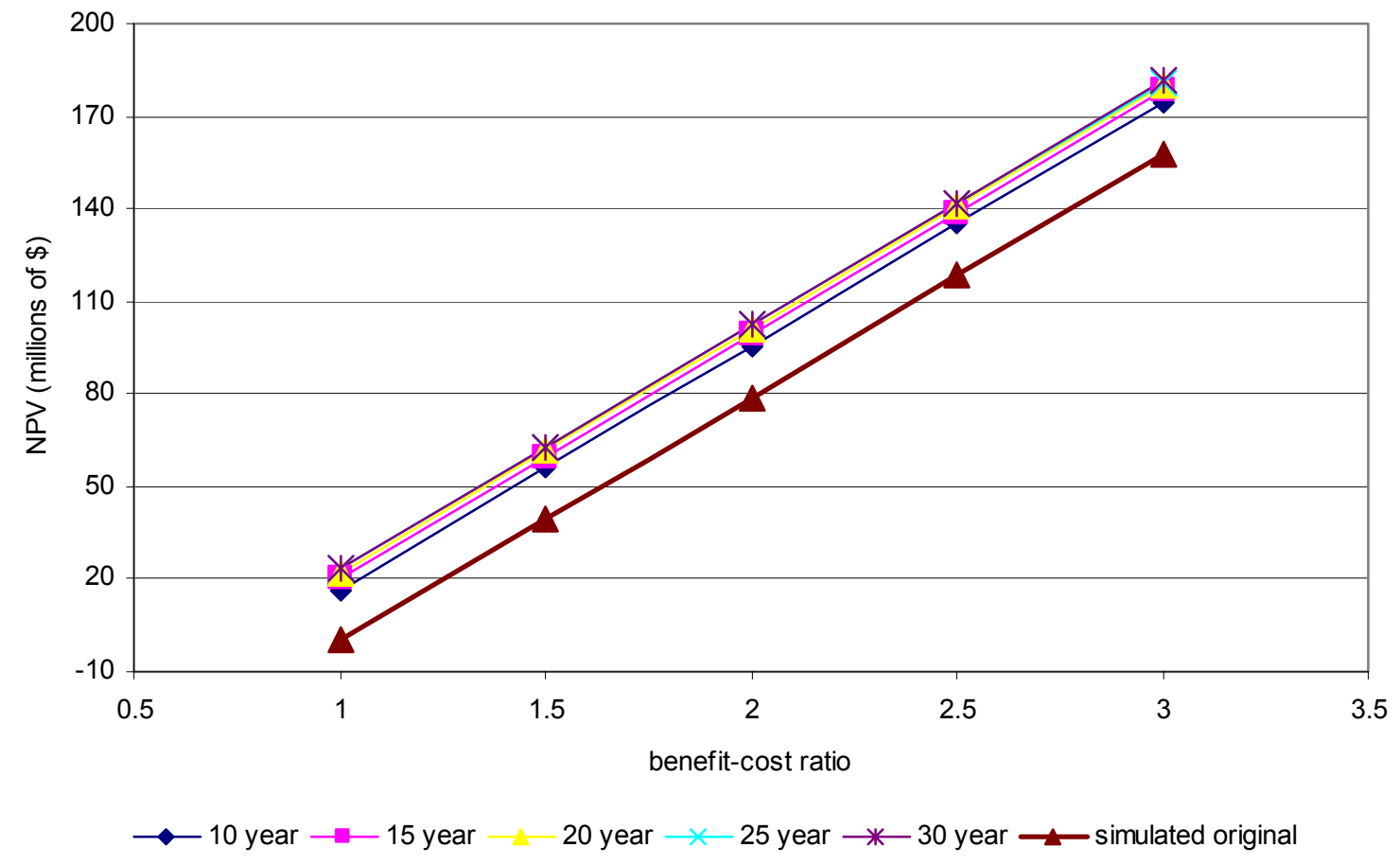

Figure 4.15 SR 641 NPV with Respect to Different Values of Maturity and BenefitCost Ratio.

As expected, Figure 4.15 shows that the NPV of the project increases as the benefitcost ratio increases with or without bond financing. The slopes of the lines are equal indicating that using GARVEE bonds to finance a project with a high benefit-cost ratio is no more justified than using GARVEE bonds to finance a project with a low benefit-cost ratio. However, we have not yet considered the fact that GARVEE bond financing has the ability to expedite the project's timeline. The most powerful impact GARVEE bond financing can have on a project is the fact that the bonds allow a project to be completed sooner rather than later allowing users to realize benefits now. The next section will explore this aspect of GARVEE bond financing. 


\section{Benefits vs. Debt Service}

To justify the use of the GARVEE program for the SR 641 it is helpful to observe the economic benefits of project acceleration. Consistent with the analysis of U.S. 31, Figure 4.16 shows that the total benefit of starting this project in 2003 is greater than if the project was started in 2013 due to the fact that the savings for road users occurring later would be discounted in proportion to the length of the delay.

The expected benefits to be discounted for various periods of deferment of the project are shown in Figure 4.16. For example, if the project were initiated in 2003 the present worth of benefits in 2003 would be $\$ 158.0$ million (using a discount rate equal to $8 \%$ and a benefit cost ratio of 2.0). However, if the project construction would start in 2013, the present worth of benefits would be 73.2 million. Accelerating the project by 10 years can be viewed as yielding an $\$ 84.8$ million increase in marginal benefits.

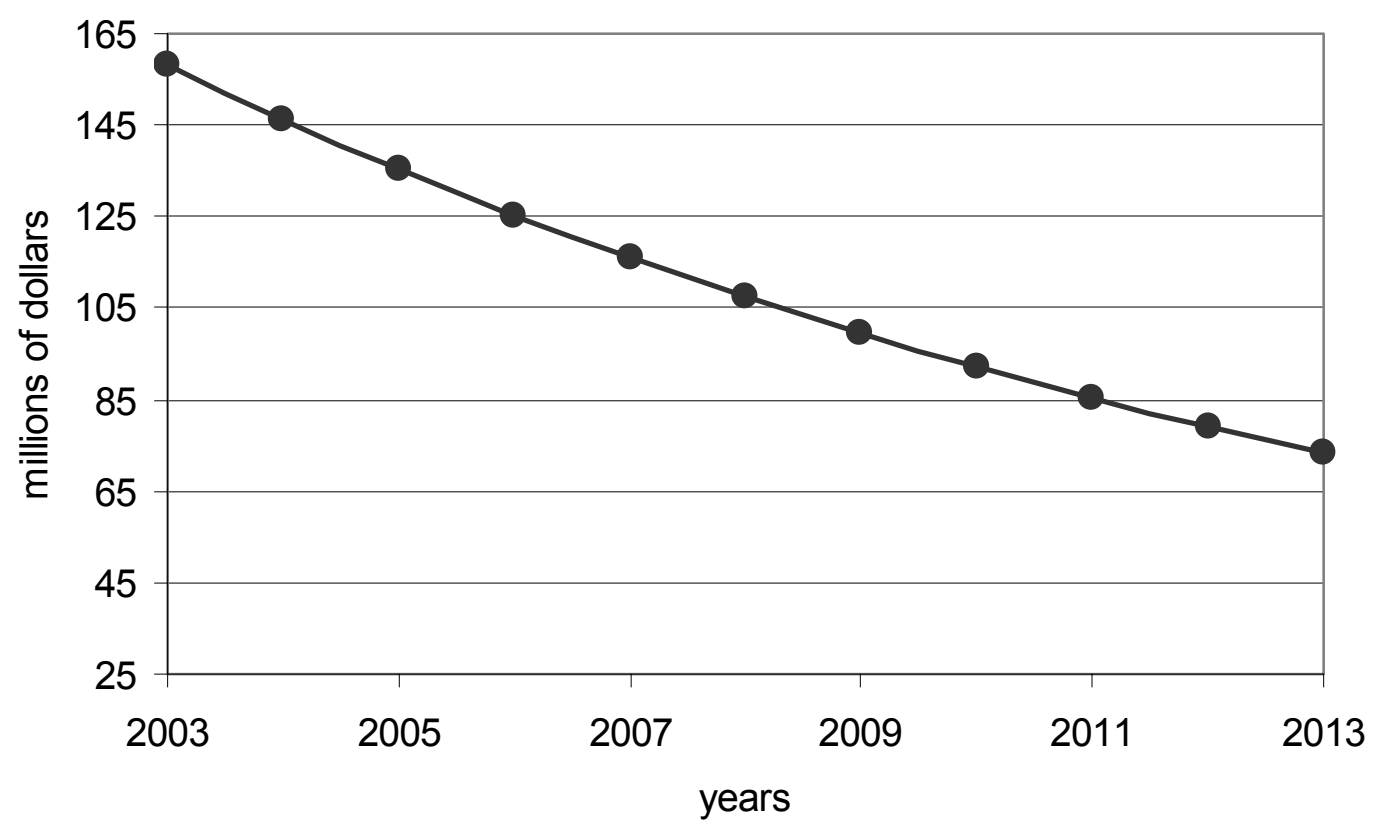

Figure 4.16 SR 641 Present Worth of Benefits in 2003.

Looking at the change in user benefits vs. the change in debt service due to the project's acceleration yields the following results illustrated in Figure 4.17. Sensitivity analysis was performed in Microsoft Excel, applying different values for the critical variables mentioned above to observe the change in present worth (PW) of total debt 
service over the bond life cycle vs. the decrease of discounted benefits over time. Results of such an analysis are shown in Figure 4.17. It demonstrates the PW in 2003 of total debt service resulting from bond issuance in various years, along with the PW of benefits as in Figure 4.16. The amount of the GARVEE bonds issued has been assumed as a percentage (from 20 to 100 percent) of the total project cost.

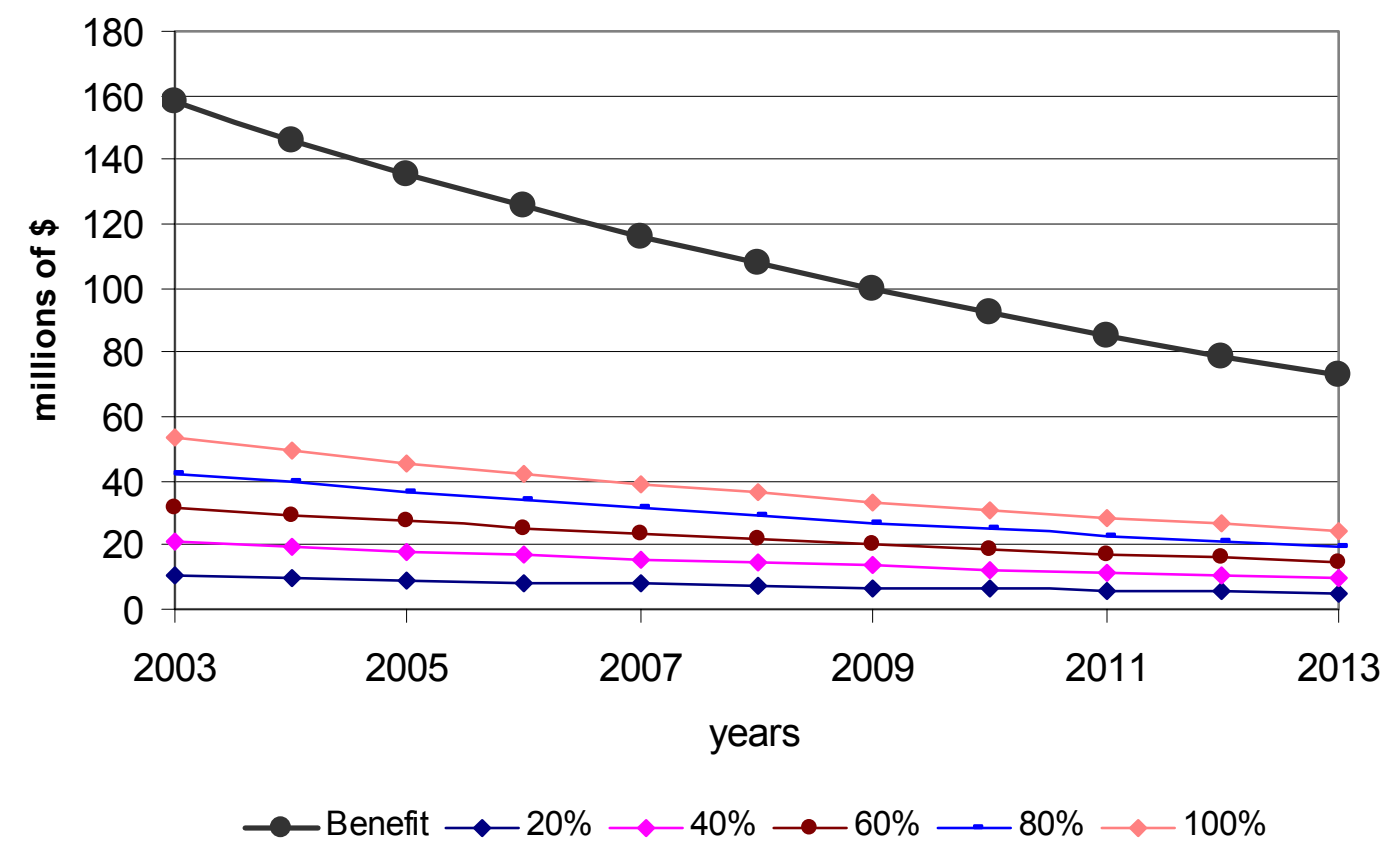

Figure 4.17 SR 641 Present Worth of Benefits and Total Debt Service in 2003.

Figure 4.17 represents the scenario when the maturity of the bond is assumed to be 10 years, the coupon rate 4.875 percent and the discount rate eight percent. The amount to be issued was determined as a percentage (from 20 percent to 100 percent) of the total project cost. The results summarized in Figure 4.17 are consistent with the results found in the analysis of U.S. 31. The graph shows that the PV of the benefits decreases at a faster rate than does the PV of the debt service. This indicates that the magnitude of the project's benefits-cost ratio should influence INDOT's decision regarding the issuance of GARVEE bonds to expedite a project. The higher the project's benefit-cost ratio, the more justification INDOT has for funding a project with debt because a higher benefit-cost ratio will result in a higher "gap" between the PW of the 
benefits and the PW of the debt service. As previously stated, it is not beneficial to wait for a lower debt service while losing much more in user benefits.

As discussed in the analysis of U.S. 31, incorporating inflation cost into the calculation of the PW of debt service increases the value of debt service as the amount issued increases over time (Figure 4.18). The avoidance of cost increases due to inflation is another financial advantage for executing the project sooner.
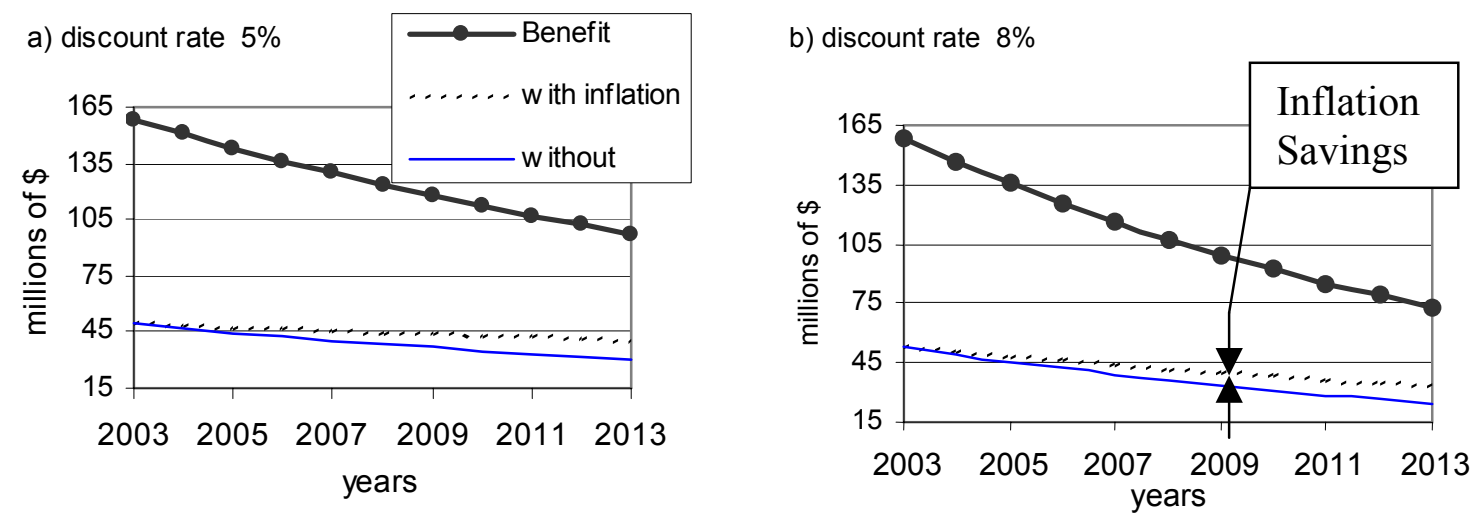

Figure 4.18 SR 641 Discounted Benefit and PW of Debt Service in 2003 with Incorporated Inflation Factor.

As with U.S. 31, the results of this analysis show that it is feasible to use the GARVEE program as a financing technique for the SR 641 project. Even though GARVEE financing might be more expensive, comparing annual debt service payments with the original project cost, it would allow INDOT to arrange construction financing all at once and realize project benefits sooner.

\subsubsection{I-69 (Evansville-to-Indianapolis)}

One of the largest projects INDOT wishes to begin is the I-69 Evansville-toIndianapolis Project, establishing a highway link between Indianapolis and Evansville, which also is part of a vital national priority, National I-69. The objective of this project is to meet transportation and economic needs throughout southwest Indiana by providing a faster, more direct route for trips between the two cities. That implies the completion of 
I-69 as an Interstate highway from I-64 north of Evansville to I-465 south of Indianapolis. The Environmental Impact Study (EIS) of the project is on schedule considering three to five alternatives currently. The final EIS report will be ready by the end of 2002. INDOT estimates that the I-69 project will cost approximately $\$ 1.2$ billion. The future resources available for INDOT construction projects do not allow inclusion of the I-69 project in the construction program for the next 18 years.

This analysis will investigate the option of using GARVEE bonds to finance the construction of I-69. Using GARVEE bonds will allow INDOT to provide the expected benefits of the interstate eighteen years ahead of the current schedule. For this analysis we will assume that construction could begin as early as 2005 and be completed by 2008 . We will also assume that user benefits begin in 2009. Implicit in this assumption is that under INDOT's current financing plan the construction would be carried out between 2023 and 2026, with user benefits beginning in 2027. All monetary values are given in 2005 dollars unless otherwise noted.

\section{Amount issued in bonds}

As previously discussed, there are no restrictions limiting the percentage of a project's cost that can be borrowed using GARVEE bonds. As with the previous two case studies, 10 different scenarios were explored between 10 and 100 percent of the $\$ 1.2$ billion cost of I-69.

\section{Coupon interest rate}

For this case study, interest rates similar to those available for U.S. Treasury bonds during March 2002 were used.

\section{Maturity}

This analysis considered bonds with maturities in the range between 10 and 30 years. 


\section{Discount rate}

Experience of other states shows that GARVEE bonds would most likely receive a strong, investment grade credit rating and the interest rate could be set around 4-6 percent, depending on factors such as the situation in the financial market, the credit rating of bonds, and the bond maturity. A sensitivity analysis of using several discount rates in the range of 3 to 9 percent was conducted for I-69 to ensure the economic viability of using GARVEE bond financing.

\section{Annual Debt Service}

The annual debt service was calculated using the method previously outlined in the analyses of U.S. 31 and SR 641. For example, assuming an interest rate of seven percent, if GARVEE bonds are issued for the entire amount needed to fund I-69 with a coupon rate of 5.375 percent and maturity of 30 years, the annual debt service will be

$$
5.375 \% \text { of } \$ 1200+\$ 1200 * \frac{0.07}{(1+0.07)^{30}-1}=77.2 \text { million }
$$

Assuming the federal apportionment as \$723 million [INDOT, 2001a], the federal portion of the debt service would become approximately 8.5 percent of the federal apportionment. That means the annual amount of federal funds INDOT could spend on other programs would be reduced by about $\$ 61.8$ million following the 80:20 match rule. The annual debt service amounts for different values of interest rates and bond terms are given in Table 4.5. 
Table 4.5 I-69 Annual Debt Service for \$1.2 Billion Bond Issuance (in million dollars).

Year 2005

\begin{tabular}{|c|c|c|c|c|c|c|}
\hline \multirow[b]{2}{*}{$\begin{array}{c}\text { Term } \\
\text { (years) }\end{array}$} & \multirow{2}{*}{$\begin{array}{l}\text { Interest } \\
\text { Rate }\end{array}$} & \multicolumn{3}{|c|}{ Annual Payment } & \multirow{2}{*}{$\begin{array}{c}\text { Federal } \\
\text { Apportionment }\end{array}$} & \multirow{2}{*}{$\begin{array}{c}\text { Federal Share of } \\
\text { Debt Service as \% of } \\
\text { Apportionment }\end{array}$} \\
\hline & & $\begin{array}{c}80 \% \text { Federal } \\
\text { Share }\end{array}$ & $\begin{array}{c}20 \% \text { State } \\
\text { Match }\end{array}$ & Total & & \\
\hline 10 & $4.875 \%$ & 116.3 & 29.1 & 145.4 & 723 & $16.1 \%$ \\
\hline 15 & $5.000 \%$ & 86.2 & 21.6 & 107.8 & 723 & $11.9 \%$ \\
\hline 20 & $5.125 \%$ & 72.6 & 18.2 & 90.8 & 723 & $10.0 \%$ \\
\hline 25 & $5.250 \%$ & 65.6 & 16.4 & 82.0 & 723 & $9.1 \%$ \\
\hline 30 & $5.375 \%$ & 61.8 & 15.4 & 77.2 & 723 & $8.5 \%$ \\
\hline
\end{tabular}

INDOT must decide what percentage of its annual federal apportionment it is willing to leverage to expedite this project. As discussed in the analysis of U.S. $31,11 \%$ could be used as an acceptable level based on the experience of other states. Figure 4.19 shows the portion of the federal apportionment demanded by I-69 under different maturities. Critical variables (interest rates, maturity, and amount issued) were chosen as in Table 4.5.

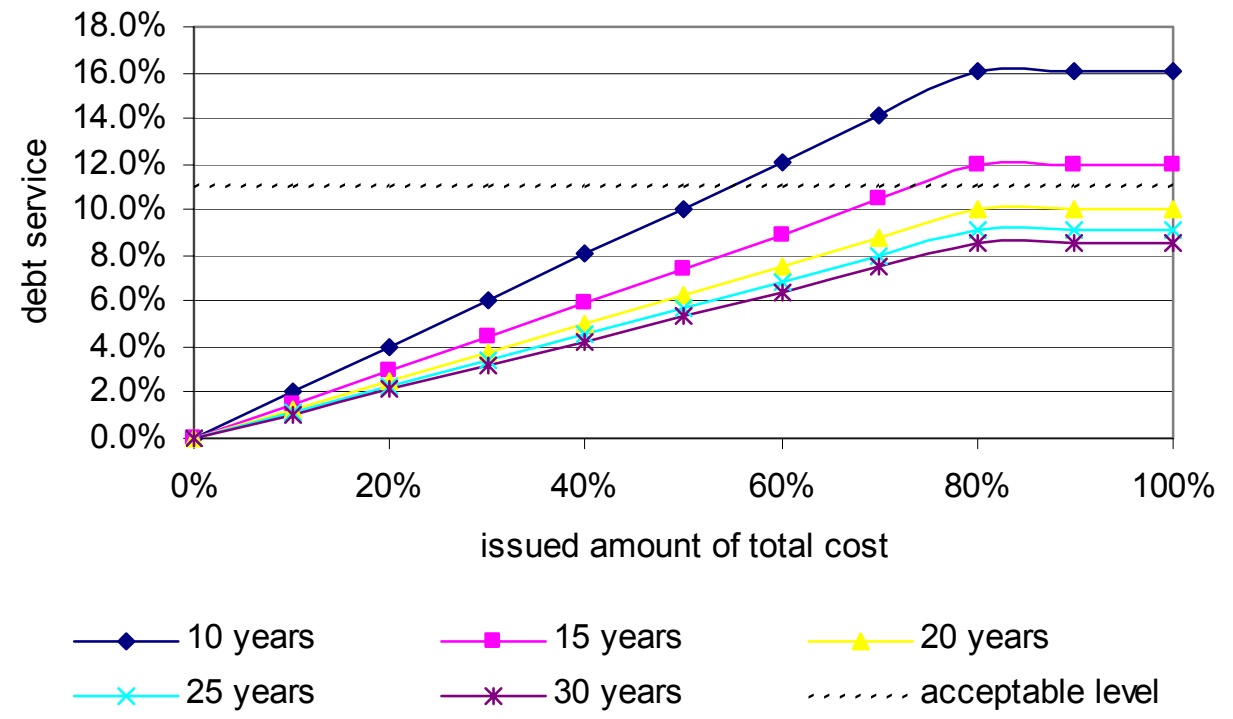

Figure 4.19 I-69 Annual Debt Service in Percents of Federal Apportionment in 2005 for Different Maturity Bonds. 
Figure 4.19 illustrates that I-69 could be financed using GARVEE bonds. Financing this project with GARVEE bonds will significantly reduce the amount of INDOT's federal apportionment remaining for other projects and obligations. To maintain similar debt level as other states INDOT would be forced into one or more of the following three solutions:

- Choose longer maturity bonds

- Partially fund I-69 with GARVEE bonds

- Limit the use of GARVEE bonds for other projects

Notice that we see the same trends here as we did in the analysis of U.S. 31 and SR 641. The greater the amount issued, the greater is the annual debt service. Also, the annual debt service decreases with increasing bond life. Finally, when 80 percent of the project's cost is reached the graph becomes flat because the maximum percentage of federal apportionment that INDOT can receive for GARVEE bond repayment is reached according to the " $80: 20$ " matching requirement.

\section{Net Present Value}

The NPV of financing I-69 through GARVEE bonds will be calculated using the following equation previously explained [Ross, 1999]:

$$
N P V_{\text {GARVEE }}=P V \text { of Amount Issued }-P V \text { of }(\text { Interest }+ \text { Face Value })
$$

The NPV calculations of financing were completed for different scenarios by changing the percentage of the project cost issued as debt and the maturity of the bonds. Figure 4.20 shows the NPV of financing the project assuming an interest rate of seven percent. 


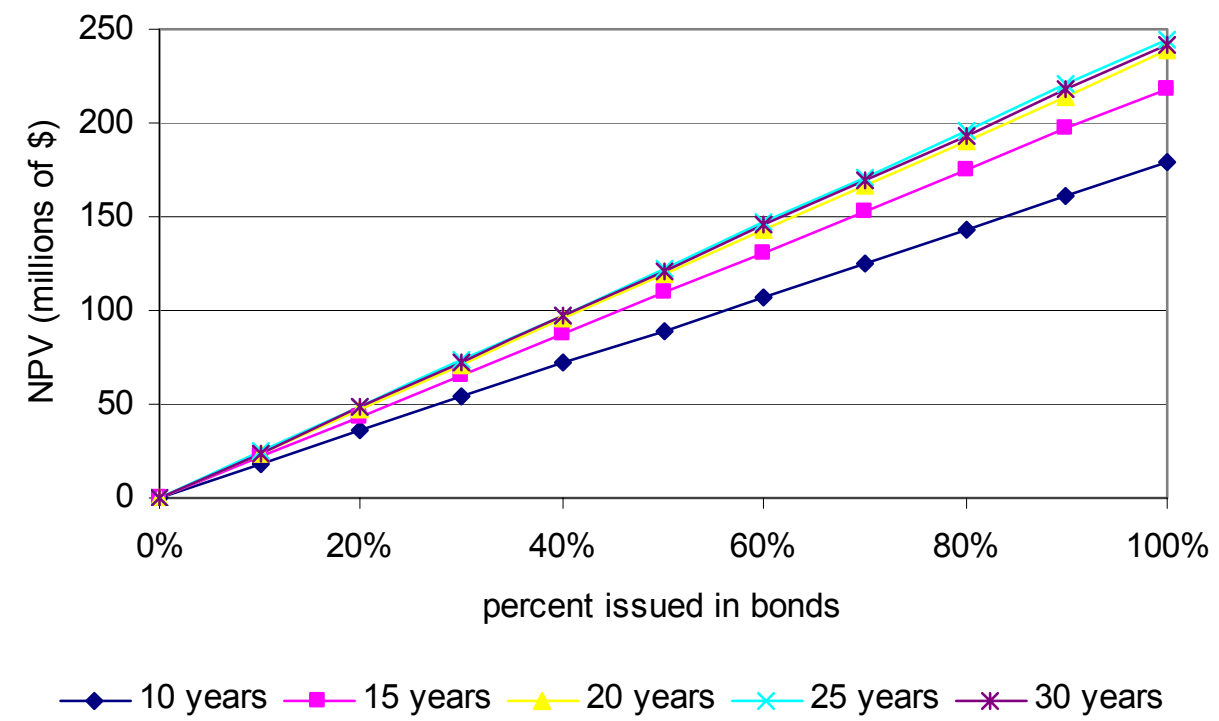

Figure 4.20 I-69 NPV of GARVEE Financing Transaction (Discount Rate 7\%).

Figure 4.20 illustrating the NPV of financing of I-69 displays similar results as found in the analyses of U.S. 31 and I-69. First, the NPV of financing the project increases linearly as a function of the percentage of project cost. Second, as the maturity of the bonds increase, the value from choosing a longer maturity bond diminishes. Under the assumptions made in developing Figure 4.20, bonds with a 25 -year maturity would be optimal for maximizing the value of debt financing for I-69. It must be noted that choosing a shorter maturity bond to maximize the NPV of financing will result in higher annual debt service payments, thereby diminishing a higher percentage of INDOT's federal apportionment available for other projects. Clearly, a trade-off exists which must be analyzed to determine the optimal bond maturity for the project.

From Figure 4.20, it appears that the NPV of financing the project with bonds is always positive. This result begs the question, what would make the NPV of financing this project negative? To answer this question a sensitivity analysis similar to the one conducted for SR 641 was conducted. Interest rates between 3 and 9 percent were tested. Figure 4.21 illustrates typical results assuming $100 \%$ of the project is financed with GARVEE bonds. 


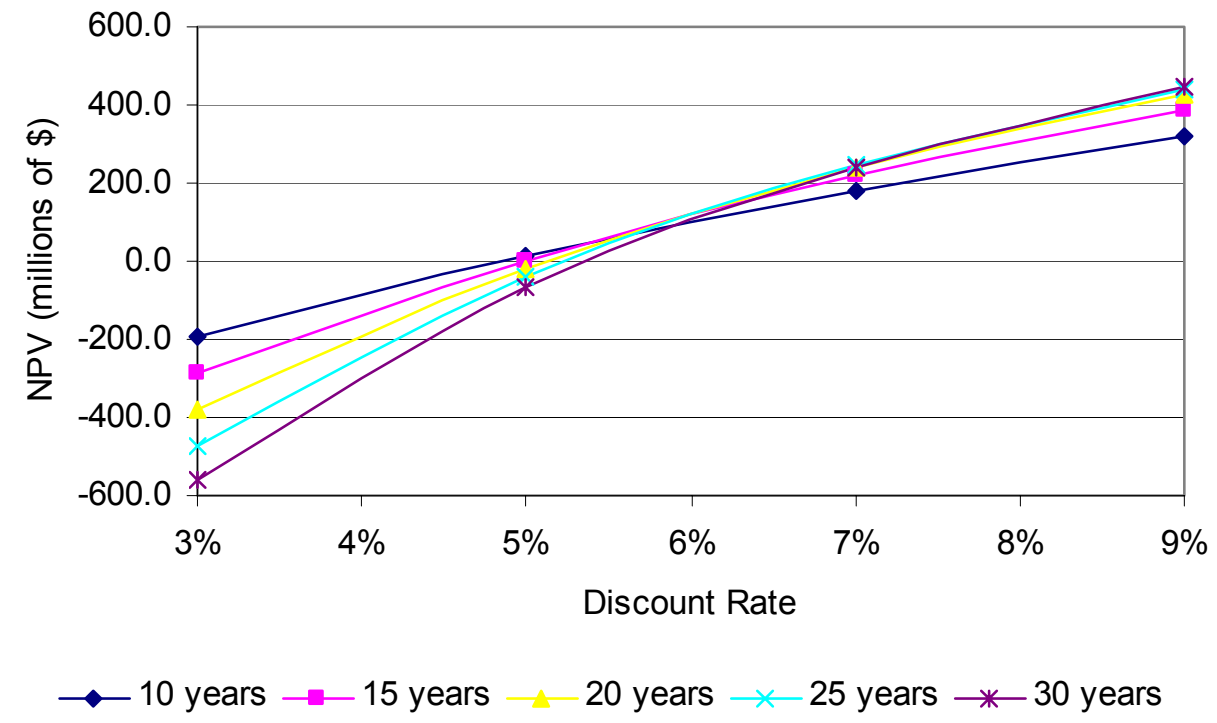

Figure 4.21 I-69 NPV of GARVEE Financing Transaction (100\% Project Financing).

Figure 4.21 displays similar trends as found in the analysis of SR 641. First, the NPV of financing SR 641 increases as the discount rate increases. Second, the point at which each maturity crosses the X-axis representing the NPV $=0$ line is different. Why? Because the coupon rate for each maturity differs. As previously explained, when the discount rate is less then the coupon rate of a bond, the NPV becomes negative and vice versa. The greater the difference between the discount rate and the coupon rate, the more the NPV moves away from zero. If the discount rate is equal to the coupon rate, the agency neither benefits, nor incurs losses by issuing bonds (NPV=0).

The preceding section investigates the financing aspects of an NPV analysis for I69. To understand the full benefits of GARVEE bond financing for this project requires an analysis of the full NPV of the project under GARVEE bond financing. As with SR 641, it will be assumed that regardless of the percentage of the project's cost chosen for debt financing and the bond maturity, the project time line will not change. 
To estimate the full NPV of I-69 under different financing scenarios, an accurate assessment of the project's benefit-cost ratio is required. A 1989 study prepared by Cambridge Systematics entitled, "The Economic Impacts of Highway Improvements in Southwest Indiana," estimated the benefit-cost ratio of constructing a freeway between Indianapolis and Evansville to be in the range of 1.23 to 1.54 [CS, 1989]. The benefitcost ratio of 1.23 was estimated using a set of "realistic" assumptions while the ratio of 1.54 was estimated using a set of "optimistic" assumptions. The Cambridge Systematics study included:

- Travel timesaving

- Changes in vehicle operating costs

- Savings in accident and injury costs

- Economic benefits excluding short-term construction

If the NPV of the project is greater than zero, the project is acceptable. By applying sensitivity analysis to the discount rate, bond maturity and percentage of project cost financed we can observe the impact GARVEE bond financing has on the project's NPV. The four graphs in Figure 4.22 illustrate the impact of using GARVEE bonds as a financing tool on the NPV of I-69 over a wide range of discount rates. We will apply an average of benefit-cost ratio estimates made by Cambridge Systematics (1.39). 


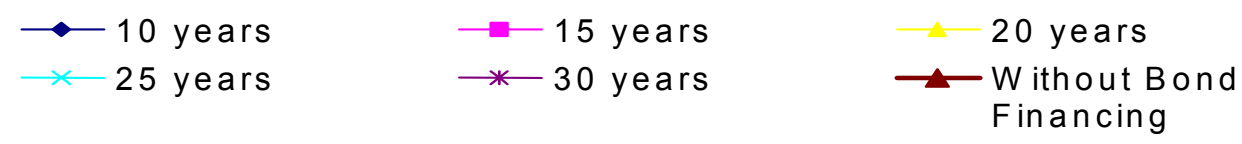

a) discount rate $=3 \%$

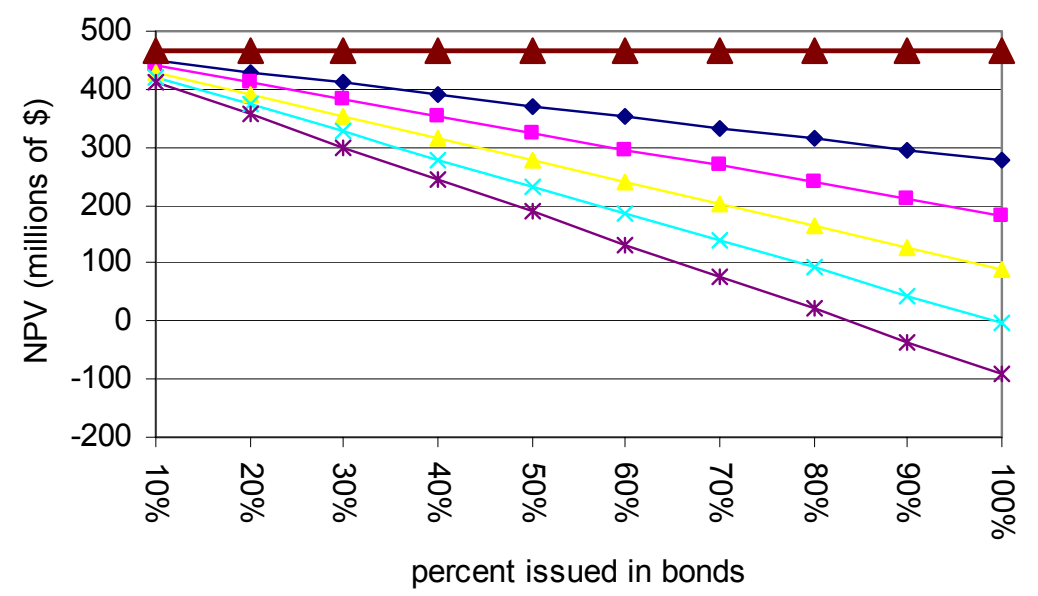

b) discount rate $=5 \%$

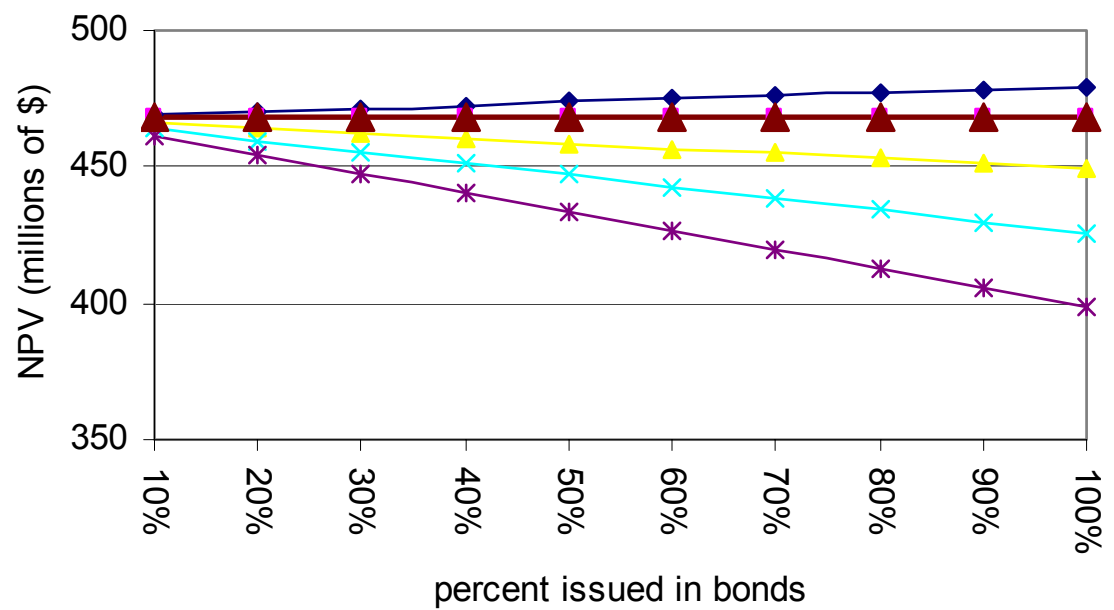


c) discount rate $=7 \%$

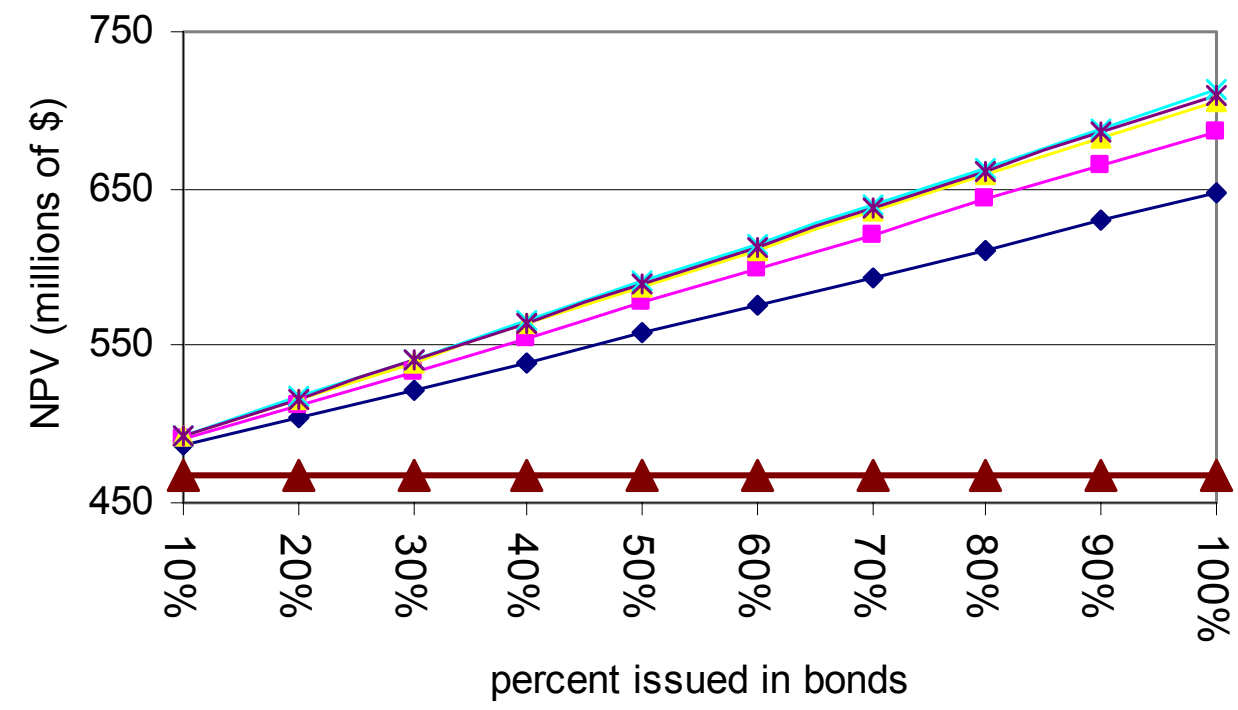

d) discount rate $=9 \%$

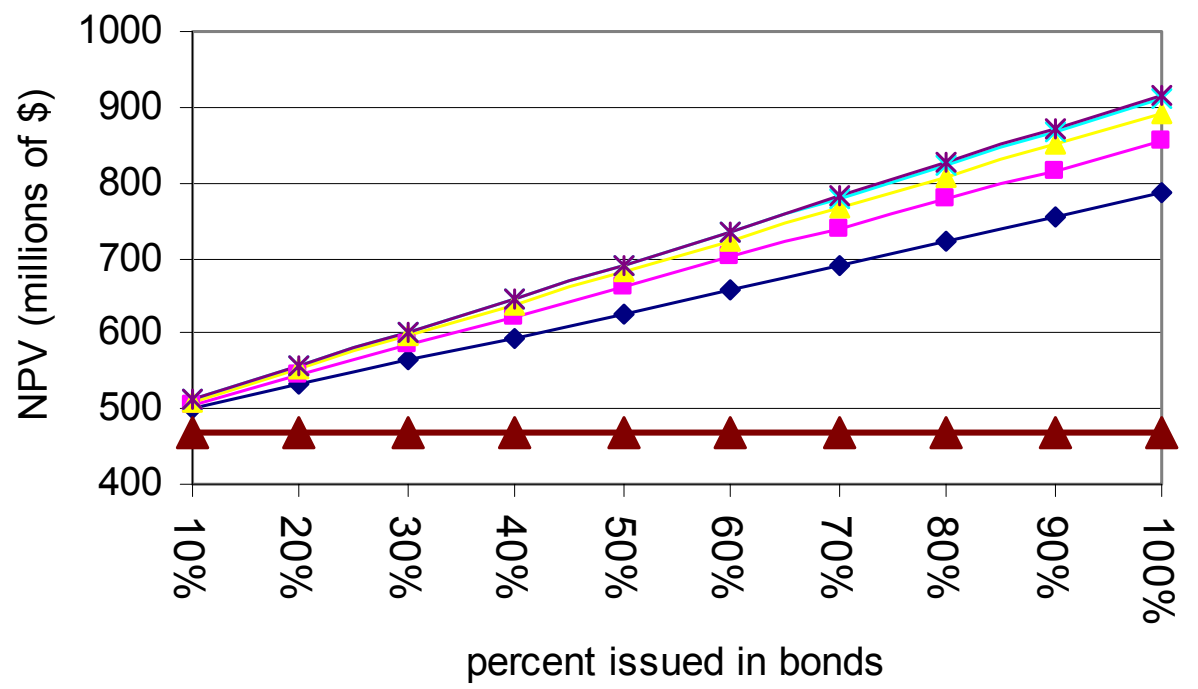

Figure 4.22 I-69 NPV with Respect to Different Values of Interest Rate, Maturity and Amount Issued in GARVEE Bonds. 
Consistent with the analyses of U.S. 31 and SR 641, Figures 4.22b and 4.22c show that GARVEE bond financing has the potential to increase the NPV of I-69 under the following condition: the coupon rate must be lower than the prevailing discount rate. Figures $4.22 \mathrm{a}$ and $4.22 \mathrm{~b}$ show that when the coupon rate is higher than the discount rate GARVEE bond financing can decrease the NPV of the project. If the benefits derived from expediting the project outweigh the additional cost of financing when the coupon rate is higher than the discount rate then the shortest maturity bond possible should be chosen.

Up to this point the analysis has been conducted using a benefit cost ratio of 1.39 . As with SR 641, a sensitivity analysis to determine the trends associated with different benefit-cost ratios was conducted. Figure 4.23 illustrates these trends assuming 100\% project financing and a seven percent discount rate with benefit-cost ratios between 1.0 and 2.5 .

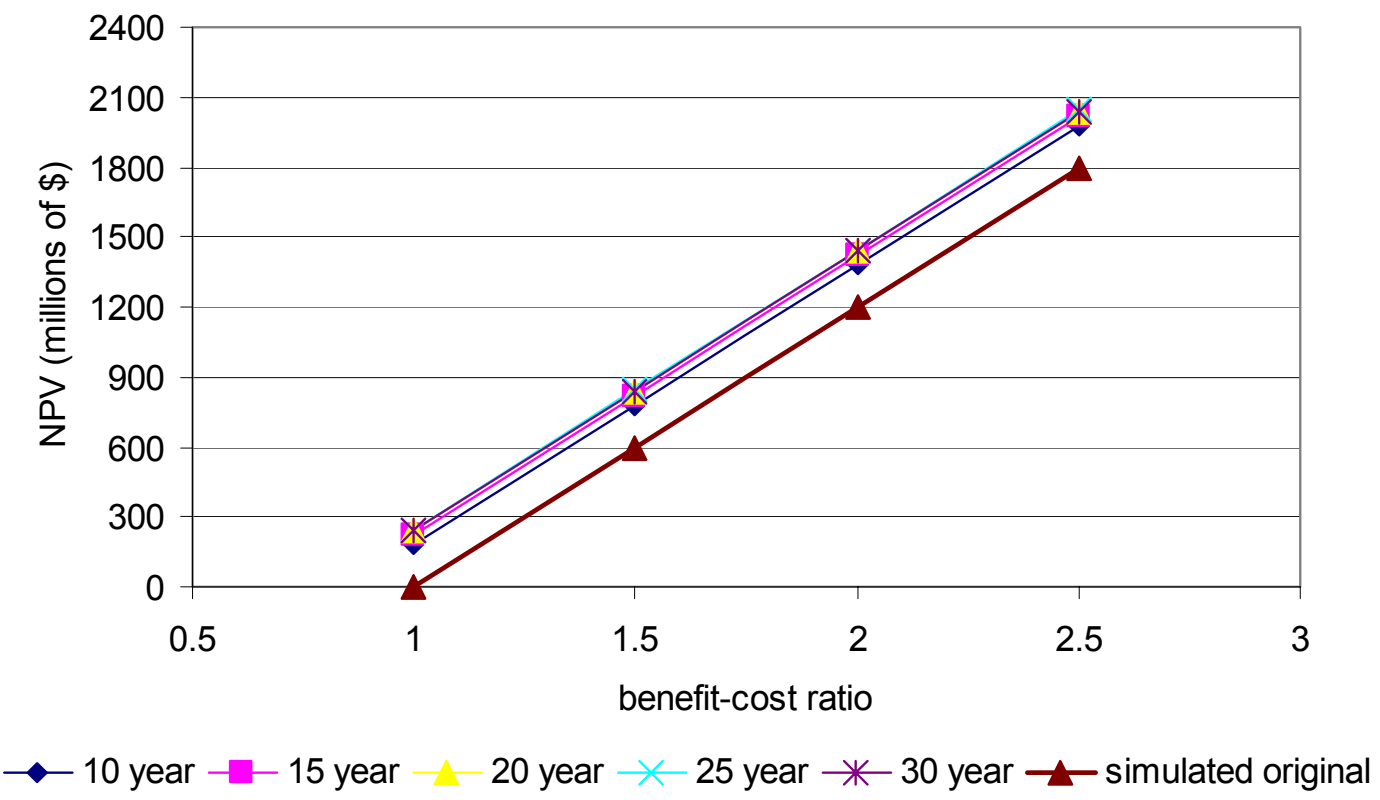

Figure 4.23 I-69 NPV with Respect to Different Values of Maturity and BenefitCost Ratio. 
Figure 4.23 shows that the NPV of the project increases as the benefit-cost ratio increases with or without bond financing. The slopes of the lines are equal indicating that using GARVEE bonds to finance a project with a high benefit-ratio is no more justified than using GARVEE bonds to finance a project with a low benefit-cost ratio. Again, this result is not conclusive because we have not yet considered the ability of GARVEE bond financing to expedite the project's timeline.

\section{Benefits vs. Debt Service}

To justify the use of the GARVEE program for I-69 we need to observe the economic benefits of project acceleration. Consistent with the analyses of U.S. 31 and SR 641, Figure 4.24 shows that the total benefit of starting this project in 2005 is greater than if the project was started in 2023 due to the fact that the savings for road users occurring later would be discounted in proportion to the length of the delay.

The expected benefits to be discounted for various periods of deferment of the project are shown in Figure 4.24. For example, if the project were initiated in 2005, the present worth of benefits in 2005 would be $\$ 1.7$ billion (using a discount rate equal to 7\% and a benefit cost ratio of 1.39). However, if the project construction would start in 2023, the present worth of benefits would be 493.5 million. Accelerating the project by 18 years can be viewed as yielding a $\$ 1.2$ billion increase in marginal benefits.

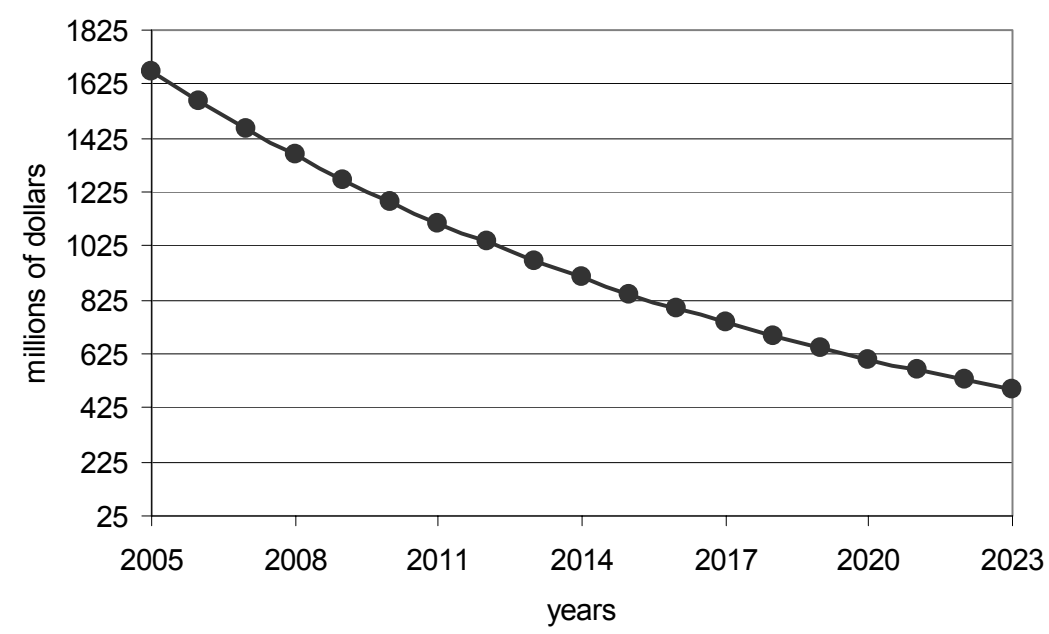

Figure 4.24 Present Worth of Benefits of I-69 in 2005. 
Looking at the change in user benefits vs. the change in debt service due to the project's acceleration yields the following results illustrated in Figure 4.25. Sensitivity analysis was performed in Microsoft Excel, applying different values for the critical variables mentioned above to observe the change in present worth (PW) of total debt service over the bond life cycle vs. the decrease of discounted benefits over time. Figure 4.25 illustrates the PW in 2005 of total debt service resulting from bond issuance in various years, along with the $\mathrm{PW}$ of benefits as in Figure 4.24. Figure 4.25 represents the scenario when the maturity of the bond is assumed to be 30 years, the coupon rate 5.375 percent and the discount rate is seven percent. The amount to be issued was determined as a percentage (from 20 percent to 100 percent) of the total project cost.

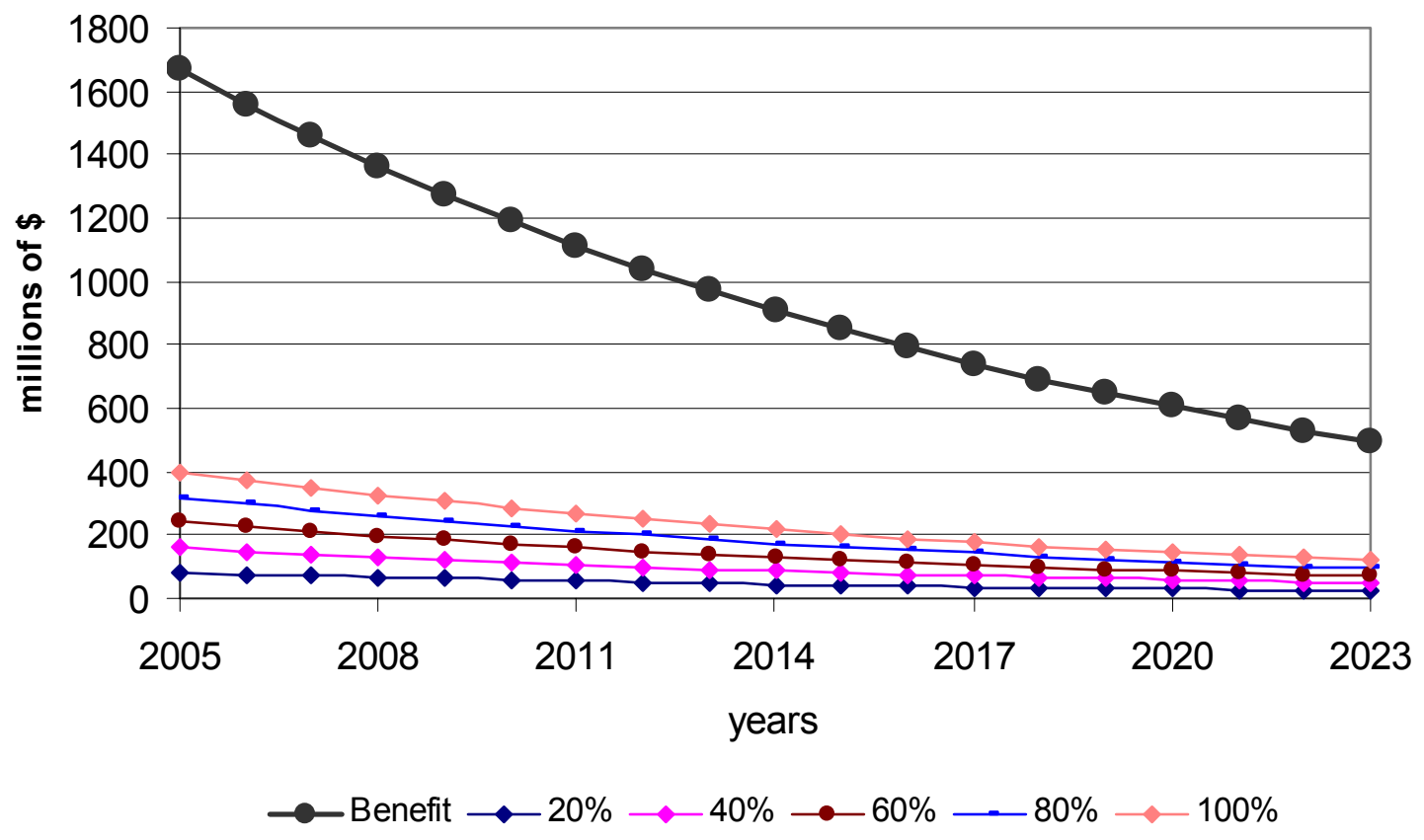

Figure 4.25 I-69 Present Worth of Benefits and Total Debt Service in 2005.

The results of the sensitivity analysis displayed in Figure 4.25 are consistent with the results of the analyses of U.S. 31 and SR 641. Again, we conclude that the higher the project's benefit-cost ratio the more justification INDOT has for funding a project with GARVEE bonds. As previously stated, it is not beneficial to wait for a lower debt service 
while losing much more in user benefits. This conclusion is supported by the fact that the PW of the benefits in Figure 4.25 decline at a faster rate than the PW of the debt service.

As discussed in the analyses of U.S. 31 and SR 641, incorporating inflation cost into the calculation of the PW of debt service increases the value of debt service as the amount issued increases over time (Figure 4.26). The avoidance of cost increases due to inflation is another financial advantage for executing the project sooner.

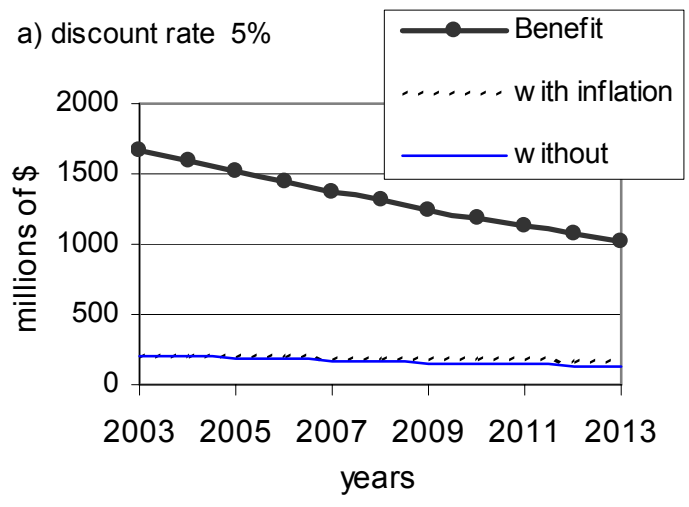

b) discount rate $8 \%$

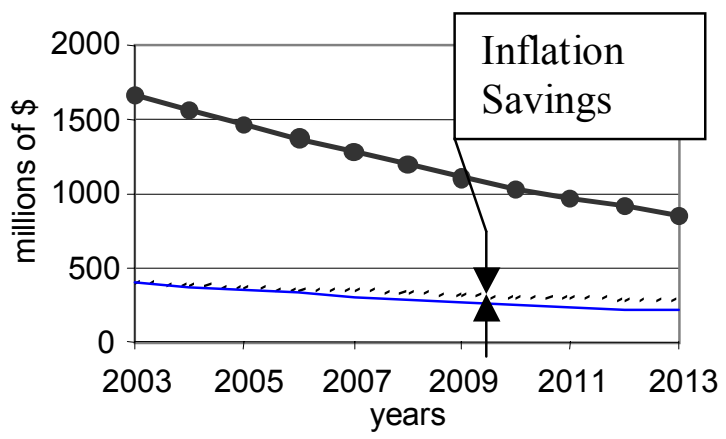

Figure 4.26 I-69 Discounted Benefit and PW of Debt Service in 2005 with Incorporated Inflation Factor.

As with U.S. 31 and SR 641, the results of this analysis show that it is feasible to use the GARVEE program as a financing technique for I-69 project. The benefits associated with expediting a project can far out weigh the additional cost associated with financing the project with GARVEE bonds.

\subsubsection{Louisville-Southern Indiana Ohio River Bridges Project}

A fourth major project that can be considered for GARVEE bond financing is the Louisville-Southern Indiana Ohio River Bridges Project (ORBP). The ORBP is a joint project between INDOT and the Kentucky Transportation Cabinet (KYTC). According to the Draft Environmental Impact Statement (DEIS) for this project published in November 2001, the purpose of this project is to "Improve cross-river mobility between Jefferson County, Kentucky and Clark County, Indiana [FHWA, INDOT \& KYTC, 2001]." The DEIS goes on to justify the need for the ORBP with the following rationale: 
- Existing and planned growth in population and employment in the downtown Louisville area and in eastern Jefferson and southeastern Clark counties;

- Traffic congestion on the Kennedy Bridge and in the Kennedy Interchange;

- Traffic safety problems in the Kennedy Interchange and on the Kennedy Bridge and its approach roadways; and

- Locally adopted transportation plans that call for two new Ohio River bridges.

The DEIS identifies and explores the environmental cost associated with this project. As of early 2002, the preferred project alternatives were yet to be selected and the costs of the alternatives under consideration at that time varied between $\$ 1.0$ and $\$ 1.8$ billion in year 2000 dollars [Hazeltine, 2002]. For this analysis we assumed that the selected alternative would have a price tag of $\$ 1.8$ billion. At this time it is expected that a major portion of the funding for the project will come from special federal legislation [Hazeltine, 2002]. Depending on the availability and timing of the special federal legislation, INDOT and KYTC could choose to fund the project using GARVEE bonds serviced by either their federal apportionments or from the special federal legislation. Making this decision would allow INDOT and KYTC to put the project on a faster track and could allow the federal government the option of providing the funding for the project over an extended period of time.

Depending on the alternative selected, INDOT's portion of the project's cost could vary between 30\% and 40\% [Hazeltine, 2002]. We assumed that INDOT's portion would be $40 \%$. To illustrate the benefits that can be gained from using GARVEE bonds as a financing tool, we also assumed that both states would fund the project from their annual federal apportionment. Under these assumptions INDOT will be responsible for $\$ 720$ million and KYTC will be responsible for $\$ 1.08$ billion. Our analysis only considered the impact of the project on INDOT. A similar analysis could be completed for KYTC. All dollar amounts are in 2000 dollars unless stated otherwise.

Currently, INDOT and KYTC have not set a date to begin construction of the ORBP, but INDOT's designated project manager for the ORBP, Mike Hazeltine, estimates that if funding was not an issue, construction could begin as early as 2005. Hazeltine also estimates that construction will take 9 to 12 years depending on the selected alternative and the robustness of funding. This analysis will assume that construction begins in 2005 and last 10 years coming to completion in 2015 if GARVEE bonds are issued. We will 
also assume that if INDOT and KYTC choose not to issue GARVEE bonds, construction will not begin until 2013 and will be completed 10 years later in 2023.

\section{Amount issued in bonds}

This analysis will follow the precedent set by the previous three GARVEE bond financing case studies. Ten different scenarios will be explored between 10 and 100 percent of the $\$ 720$ million cost of INDOT's portion of the ORBP.

\section{Coupon interest rate}

For this case study interest rates similar to those available for U.S. Treasury bonds during March 2002 will be used.

\section{Maturity}

This analysis will consider bonds with maturities in the range between 10 and 30 years.

\section{Discount rate}

A sensitivity analysis of using several discount rates in the range of 3 to 9 percent will be conducted for ORBP to ensure the economic viability of using GARVEE bond financing.

\section{Annual Debt Service}

Assuming an interest rate of seven percent, if GARVEE bonds are issued for the entire amount needed to fund ORBP with a coupon rate of 5.375 percent and maturity of 30 years, INDOT's portion of the annual debt service will be

$$
5.375 \% \text { of } \$ 720+\$ 720 * \frac{0.07}{(1+0.07)^{30}-1}=46.3 \text { million }
$$


Assuming INDOT's federal apportionment is $\$ 723$ million [INDOT, 2001a], the federal portion of the debt service would become approximately 4.3 percent of INDOT's federal apportionment. That means the annual amount of federal funds INDOT could spend on other programs would be reduced by about $\$ 37.1$ million following the 80:20 match rule. The annual debt service amounts for different values of interest rates and bond terms are given in Table 4.6.

Table 4.6 ORBP Annual Debt Service for INDOT's Portion (\$720 Million) of $\$ 1.8$ Billion Bond Issuance

(in million dollars).

Year 2000

\begin{tabular}{|c|c|c|c|c|c|c|}
\hline \multirow{2}{*}{$\begin{array}{l}\text { Term } \\
\text { (years) }\end{array}$} & \multirow{2}{*}{$\begin{array}{l}\text { Interest } \\
\text { Rate }\end{array}$} & \multicolumn{3}{|c|}{ Annual Payment } & \multirow{2}{*}{$\begin{array}{c}\text { Federal } \\
\text { Apportionment }\end{array}$} & \multirow{2}{*}{$\begin{array}{c}\text { Federal Share of } \\
\text { Debt Service as \% of } \\
\text { Apportionment }\end{array}$} \\
\hline & & $\begin{array}{c}80 \% \text { Federal } \\
\text { Share }\end{array}$ & $\begin{array}{c}20 \% \text { State } \\
\text { Match }\end{array}$ & Total & & \\
\hline 10 & $4.875 \%$ & 69.8 & 17.4 & 87.2 & 723 & $9.6 \%$ \\
\hline 15 & $5.000 \%$ & 51.7 & 12.9 & 64.7 & 723 & $7.2 \%$ \\
\hline 20 & $5.125 \%$ & 43.6 & 10.9 & 54.5 & 723 & $6.0 \%$ \\
\hline 25 & $5.250 \%$ & 39.3 & 9.8 & 49.2 & 723 & $5.4 \%$ \\
\hline 30 & $5.375 \%$ & 37.1 & 9.3 & 46.3 & 723 & $5.1 \%$ \\
\hline
\end{tabular}

INDOT must decide what percentage of its annual federal apportionment it is willing to leverage to expedite the project. As previously discussed, $11 \%$ could be used as an acceptable level based on the experience of other states. Figure 4.27 shows the portion of INDOT's annual federal apportionment demanded by ORBP under different maturities. Critical variables (interest rates, maturity, and amount issued) were chosen as in Table 4.6. 


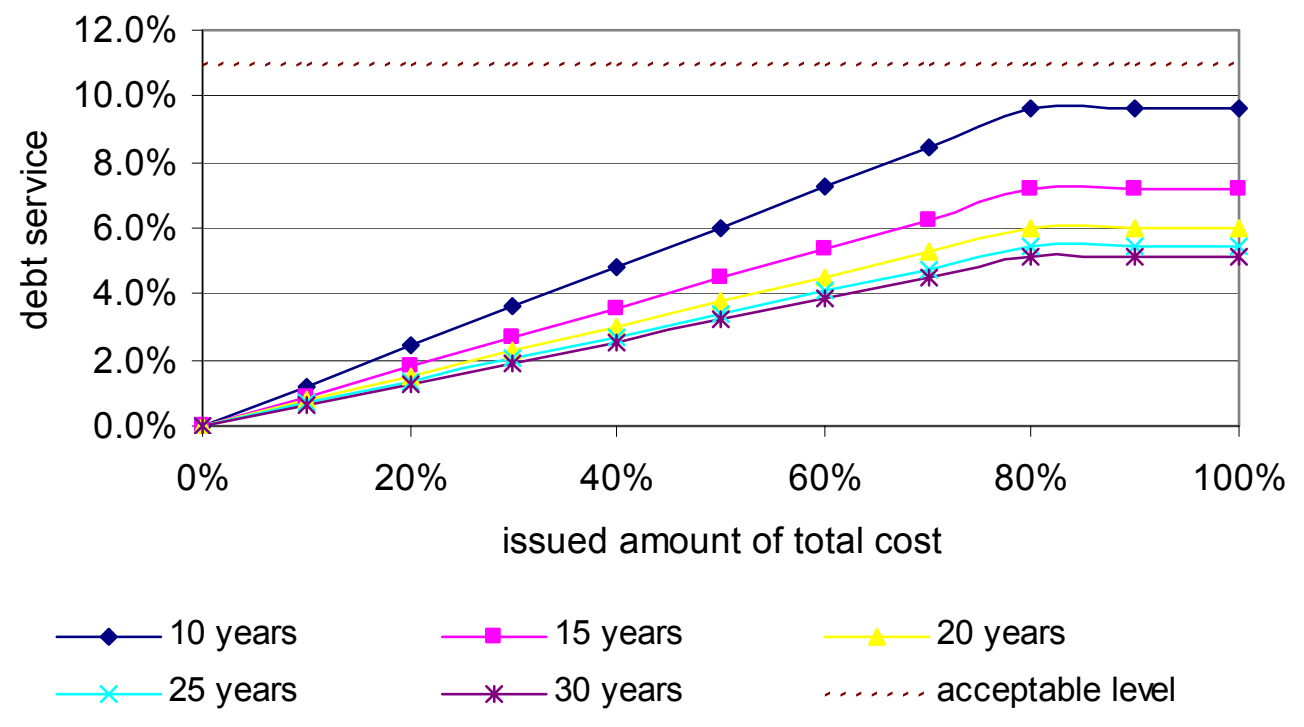

Figure 4.27 ORBP Annual Debt Service in Percents of Federal Apportionment in 2000 for Different Maturity Bonds.

Figure 4.27 illustrates that INDOT could finance its portion of the ORBP with GARVEE bonds. INDOT's willingness to take on additional debt would need to be decided based on the level of debt present from financing of other projects. In Figure 4.27, we see the same trends present in our analyses of U.S. 31, SR 641 and I-69. The greater the amount issued, the greater is the annual debt service. Also, the annual debt service decreases with increasing bond life. Finally, when 80 percent of the project's cost is reached the graph becomes flat because the maximum percentage of federal apportionment that INDOT can receive for GARVEE bond repayment is reached according to the " $80: 20$ " matching requirement.

\section{Net Present Value}

The NPV of financing the ORBP through GARVEE bonds will be calculated using the same methodology as outlined in the previous case studies. The NPV calculations of financing were completed for different scenarios by changing the percentage of the project cost issued as debt and the maturity of the bonds. Figure 4.28 shows the NPV of financing the project assuming an interest rate of seven percent. 


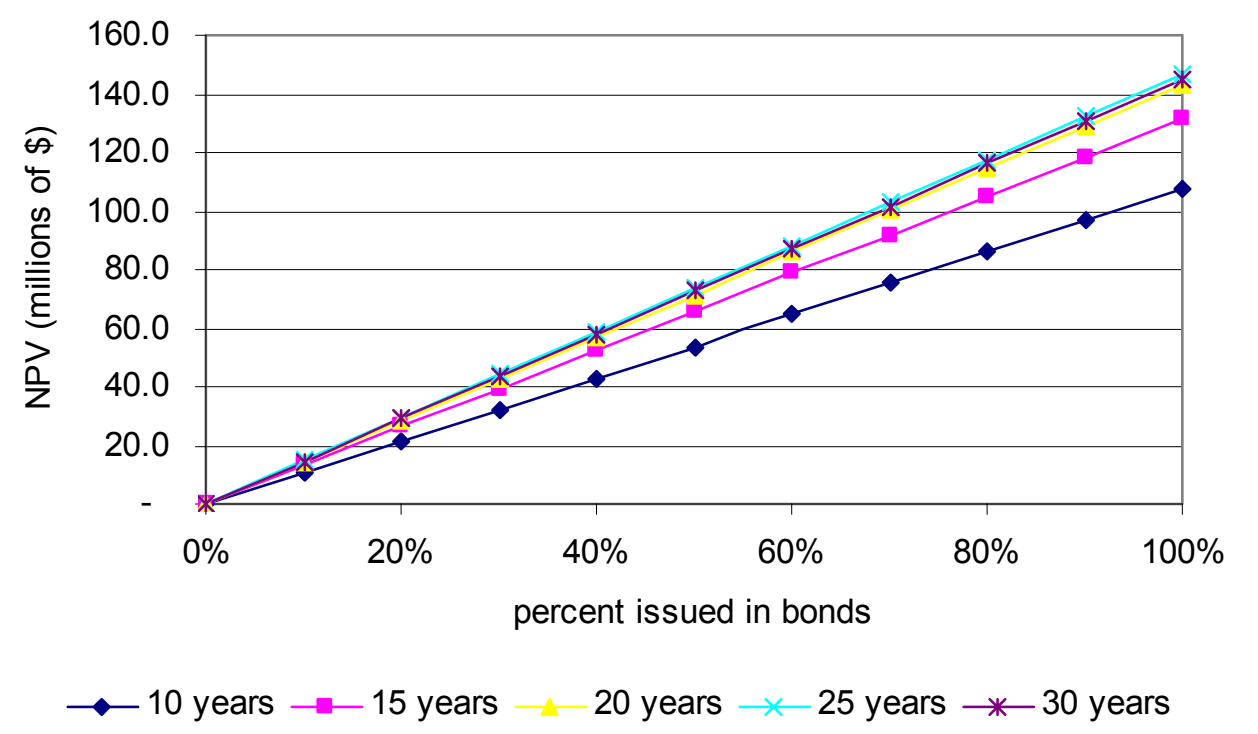

Figure 4.28 ORBP NPV of GARVEE Financing Transaction (Discount Rate 7\%).

Figure 4.28 illustrating the NPV of financing INDOT's portion of the ORBP displays the similar results as found in the previous cases. First, the NPV of financing the project increases linearly as a function of the percentage of project cost. Second, as the maturity of the bonds increase, the value from choosing a longer maturity bond diminishes. Under the assumptions displayed in Figure 4.28, bonds with a 25-year maturity would be optimal for maximizing the value of debt financing

At what point does the NPV of financing the ORBP with GARVEE bonds become negative? To answer this question a sensitivity analysis similar to the ones completed for the previous cases was conducted. Interest rates between 3 and 9 percent were tested. Figure 4.29 illustrates typical results assuming $100 \%$ of the INDOT share of the project is financed with GARVEE bonds. 


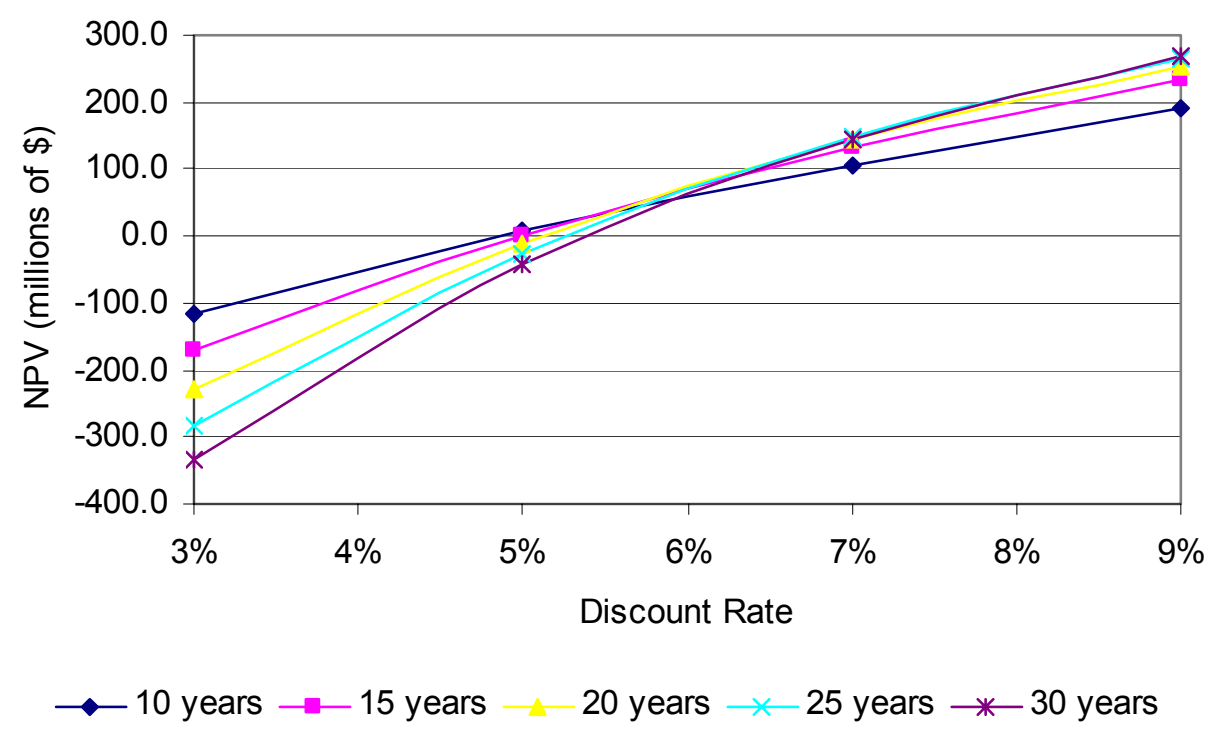

Figure 4.29 ORBP NPV of GARVEE Financing Transaction (100\% of the INDOT's Share of the Project Financing).

Figure 4.29 displays similar trends as found in the previous case studies. First, the NPV of financing the ORBP increases as the discount rate increases. Second, the point at which each maturity crosses the $\mathrm{X}$-axis (representing the point at which the financing transaction switches from $-\mathrm{NPV}$ to $+\mathrm{NPV}$ ) is different.

The preceding section investigates the financing aspects of an NPV analysis for the ORBP. To understand the full benefits of GARVEE bond financing for this project, it requires an analysis of the full NPV of the project under GARVEE bond financing. As with the previous case studies, it was assumed that regardless of the percent of project cost chosen for financing and the bond maturity, the project time line would not change.

To estimate the NPV of the ORBP under different financing scenarios, an accurate assessment of the project's benefit-cost ratio is required. While the ORBP is still in the early stages of design, two significant studies have been completed outlining the expected benefits from this project. The Ohio River Major Investment Study (ORMIS), completed in 1996 by the Kentuckiana Regional Planning and Development Agency (KIPDA), ORMIS "recommended two new bridges: one parallel to the Kennedy Bridge (I-65) between downtown Louisville and Jeffersonville, IN; and the other several miles to the east, linking the Gene Snyder Freeway (I-265/Ky. 841) in Kentucky with 
State Road 265 in Southern Indiana. The recommendation also included redesign of the Kennedy Interchange where Interstates 65, 64 and 71 merge [INDOT, 2002a].”

Following the completion of ORMIS, KYTC and INDOT selected Community Transportation Solutions, Inc. (CTS) to complete the environmental impact study for the project. This work was initiated in 1998 and the Draft Environmental Impact Statement was recently completed in November 2001 with the final report expected late in 2002. Following the final report the Federal Highway Administration will select the exact location and design of the new bridges.

CTS projected traffic flows through 2025 utilizing socioeconomic projections for population and employment levels through 2025. Chapter 2 of the DIES outlines the purpose and need of the ORBP based on these projections including a list of possible benefits [FHWA, INDOT \& KYTC, 2001].

While both ORMIS and the DIES provide significant information to support the conclusion that the ORBP is justified and a significant amount can be expected, neither provides any quantification of benefits. The absence of a benefit-cost analysis is most likely a function of the stage of the project. The alternatives under consideration each vary significantly in cost and associated benefits. Until the list of alternatives is narrowed, it is unlikely that any benefit cost ratio will be available. For the present analysis of GARVEE bond financing, a benefit-cost ratio of 2.0 was therefore assumed with sensitivity analysis being conducted in the range of 1.0 to 3.0.

By applying sensitivity analysis to the discount rate, bond maturity and percentage of project cost financed, we can observe the impact GARVEE bond financing has on the project's NPV. The four graphs in Figure 4.30 illustrate the impact of using GARVEE bonds as a financing tool on the NPV of ORBP over a wide range of discount rates. 


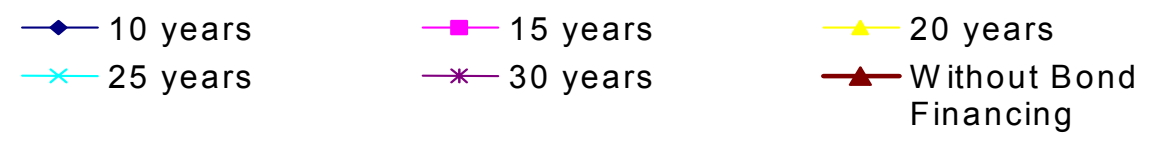

a) discount rate $=3 \%$

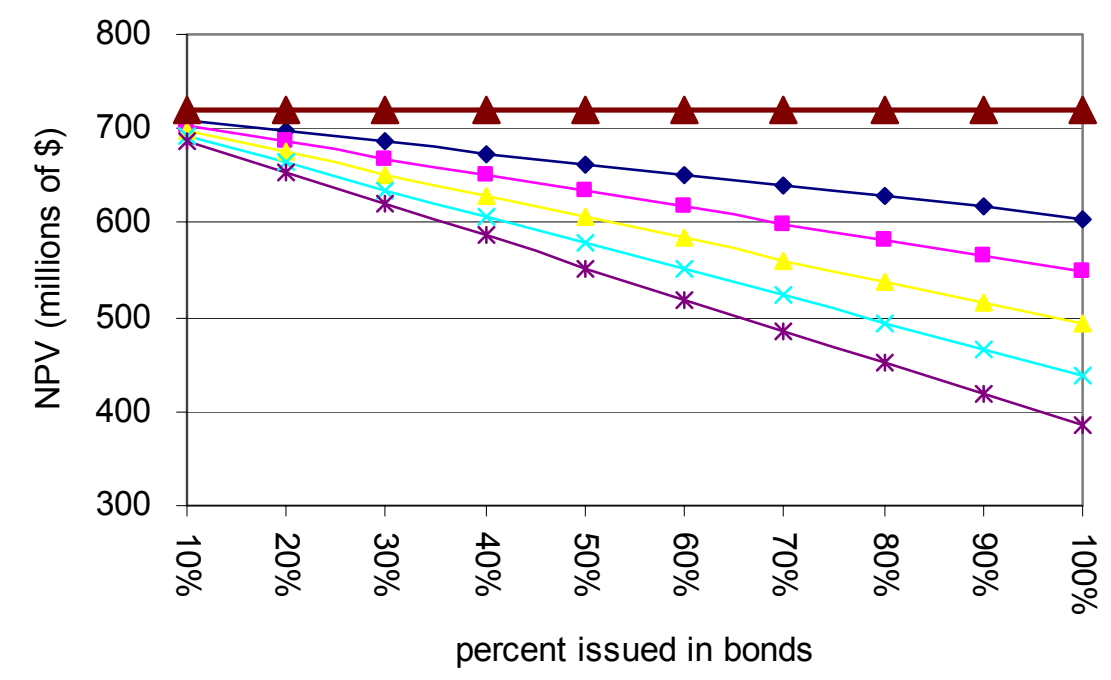

b) discount rate $=5 \%$

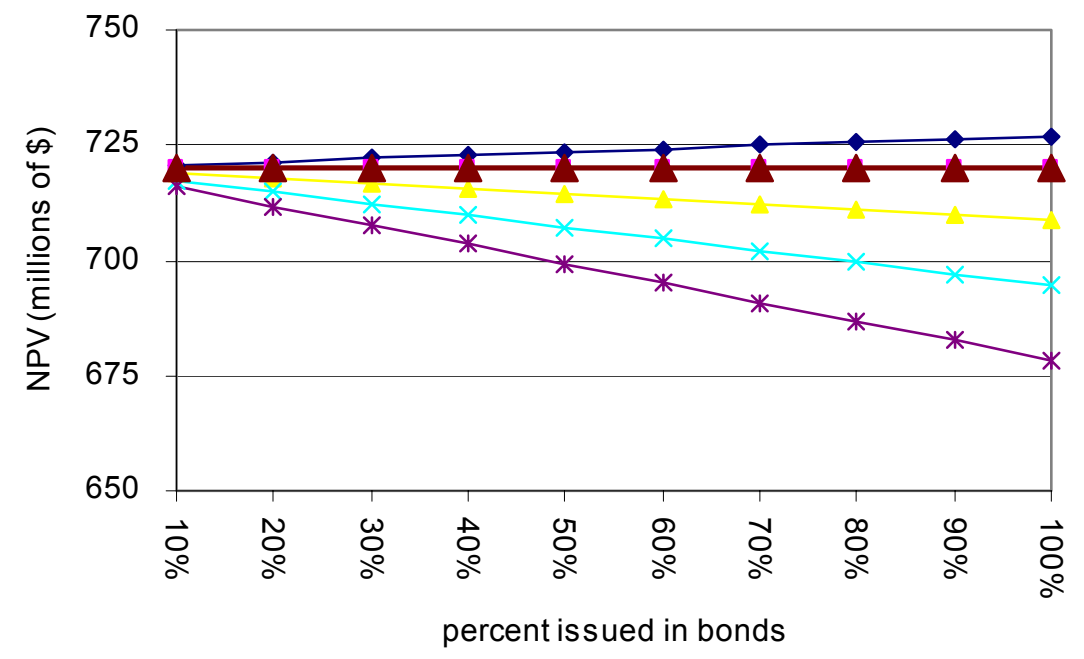


c) discount rate $=7 \%$

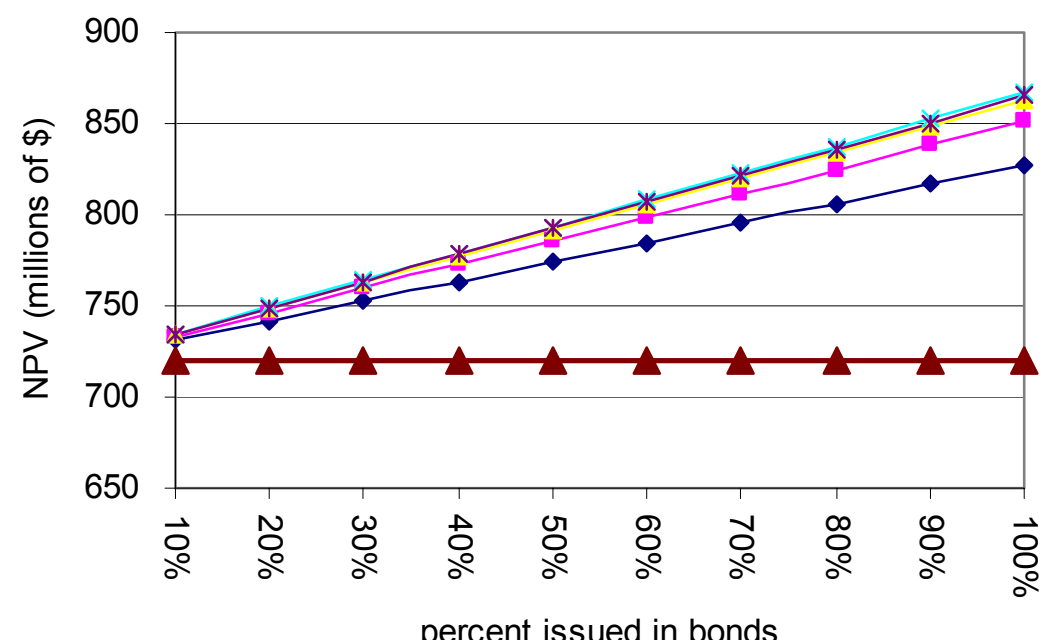

d) discount rate $=9 \%$

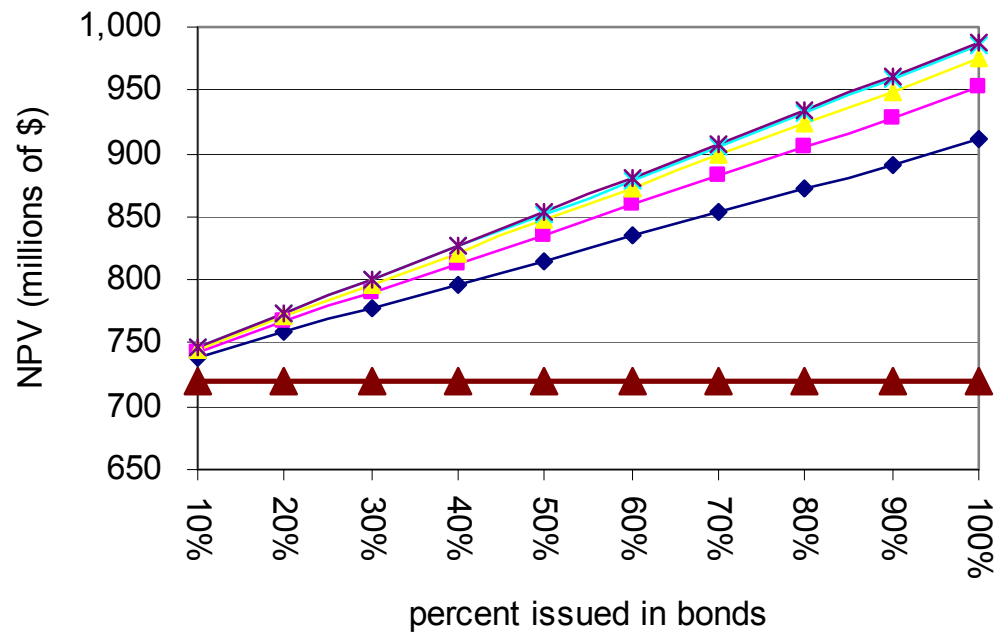

Figure 4.30 NPV of the ORBP with Respect to Different Values of Interest Rate, Maturity and Amount Issued in GARVEE Bonds. 
Consistent with the previous three analyses, Figure 4.3d shows that GARVEE bond financing has the potential to increase the NPV of ORBP under the following condition: the coupon rate must be lower than the prevailing discount rate. The graphs in Figures $4.30 \mathrm{a}$ and $4.30 \mathrm{~b}$ show that when the coupon rate is higher than the discount rate, GARVEE bond financing decreases the NPV of the project. If the benefits derived from expediting the project outweigh the additional cost of financing when the coupon rate is higher than the discount rate, then the shortest maturity bond possible should be chosen.

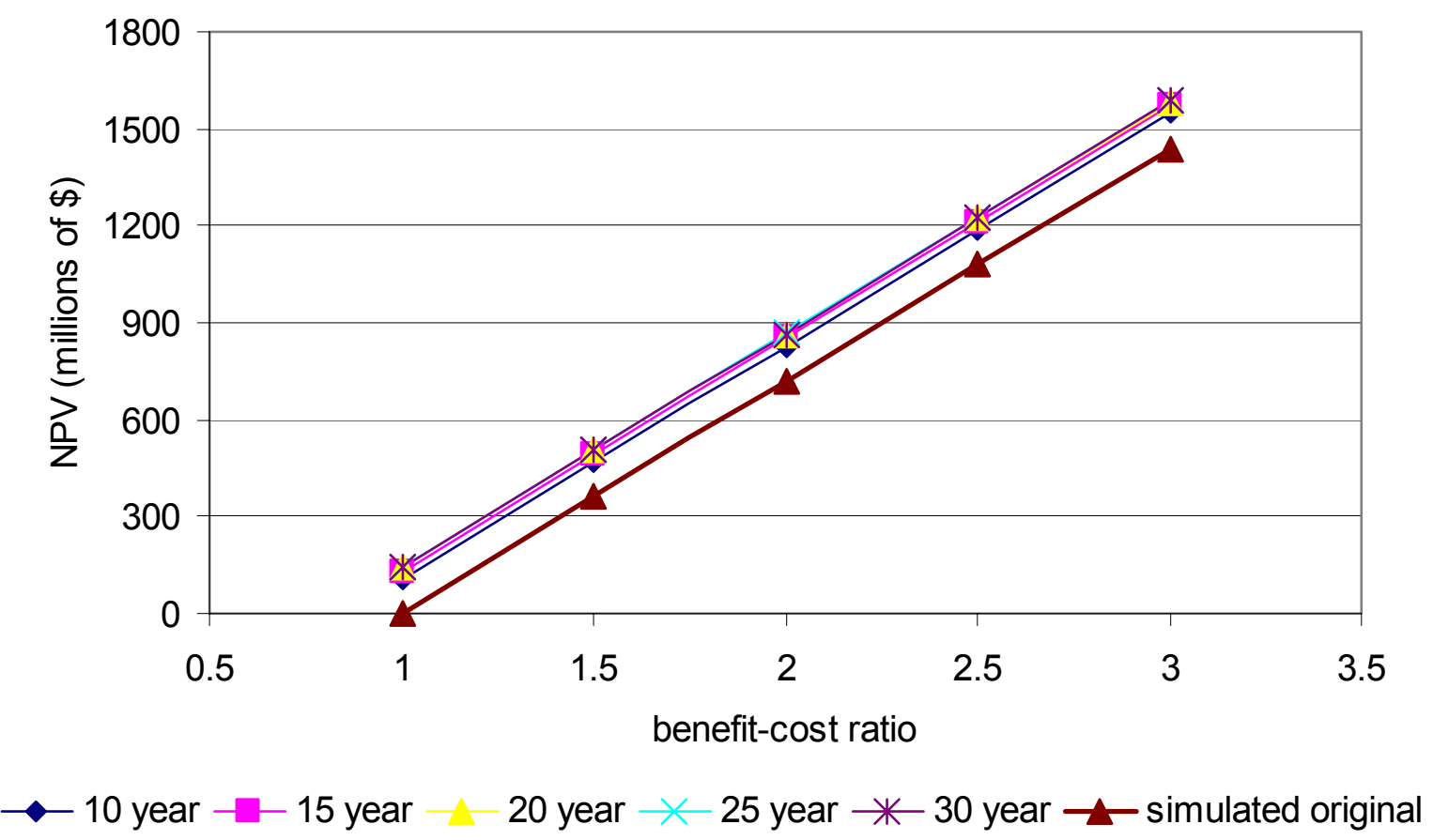

Figure 4.31 ORBP NPV with Respect to Different Values of Maturity and BenefitCost Ratio.

Figure 4.31 illustrates the trends associated with varying the benefit-cost ratio of the project between 1.0 and 3.0 assuming 100 percent financing of the INDOT share and a seven percent discount rate. The trends displayed are consistent with those found in the previous analyses. The NPV of the project increases as the benefit-cost ratio increases with or without bond financing. The slopes of the lines are equal indicating that using GARVEE bonds to finance a project with a high benefit-ratio is no more justified than 
using GARVEE bonds to finance a project with a low benefit-cost ratio. Next, we examine the ability of GARVEE bond financing to expedite the project's timeline.

\section{Benefits vs. Debt Service}

To justify the use of the GARVEE program for ORBP we need to observe the economic benefits of project acceleration. Figure 4.32 shows that the total benefit of starting this project in 2005 is greater than if the project was started in 2013. This result is due to the fact that the savings for road users occurring later is discounted in proportion to the length of the delay.

The expected benefits to be discounted for various periods of deferment of the project are shown in Figure 4.32. For example, if the project is initiated in 2005 the present worth of benefits in 2002 of Indiana's portion of the benefits would be $\$ 1.44$ billion (using a discount rate equal to $7 \%$ and a benefit cost ratio of 2.0 ). However, if the project construction would start in 2013, the present worth of Indiana's benefits in 2002 would be 684.1 million. Accelerating the project by 8 years can be viewed as yielding a \$756 million increase in marginal benefits for Indiana (this assumes that the benefits Indiana receives from the ORBP are proportional to INDOT's portion of the project's cost).

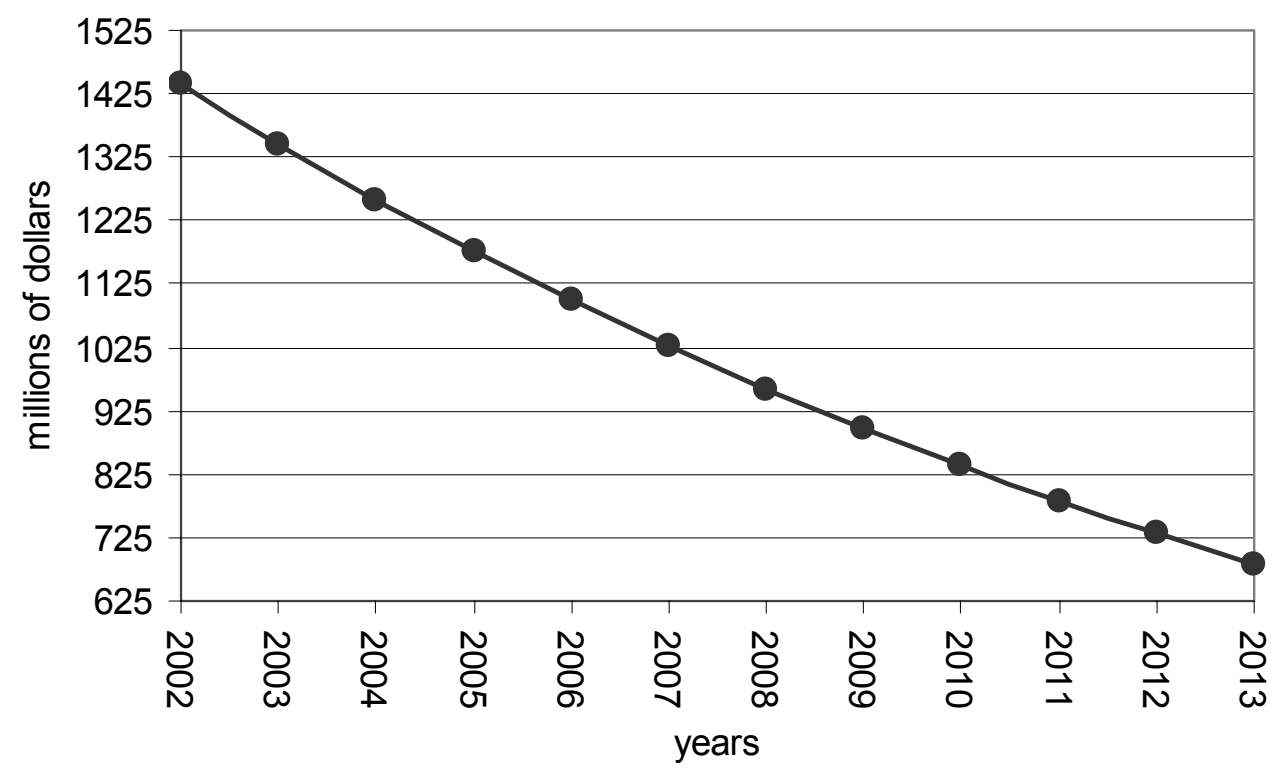

Figure 4.32 Present Worth of Benefits of ORBP in 2002 using 2000 Dollars. 
Looking at the change in user benefits vs. the change in debt service due to the project's acceleration yields the following results illustrated in Figure 4.33. Sensitivity analysis was performed in Microsoft Excel, applying different values for the critical variables mentioned above to observe the change in present worth $(\mathrm{PW})$ of total debt service over the bond life cycle vs. the decrease of discounted benefits over time. Figure 4.33 illustrates the PW in 2002 of total debt service resulting from bond issuance in various years, along with the PW of benefits as in Figure 4.32. Figure 4.33 represents the scenario when the maturity of the bond is assumed to be 30 years, the coupon rate 5.375 percent and the discount rate is seven percent. The amount to be issued was determined as a percentage (from 20 percent to 100 percent) of the total project cost.

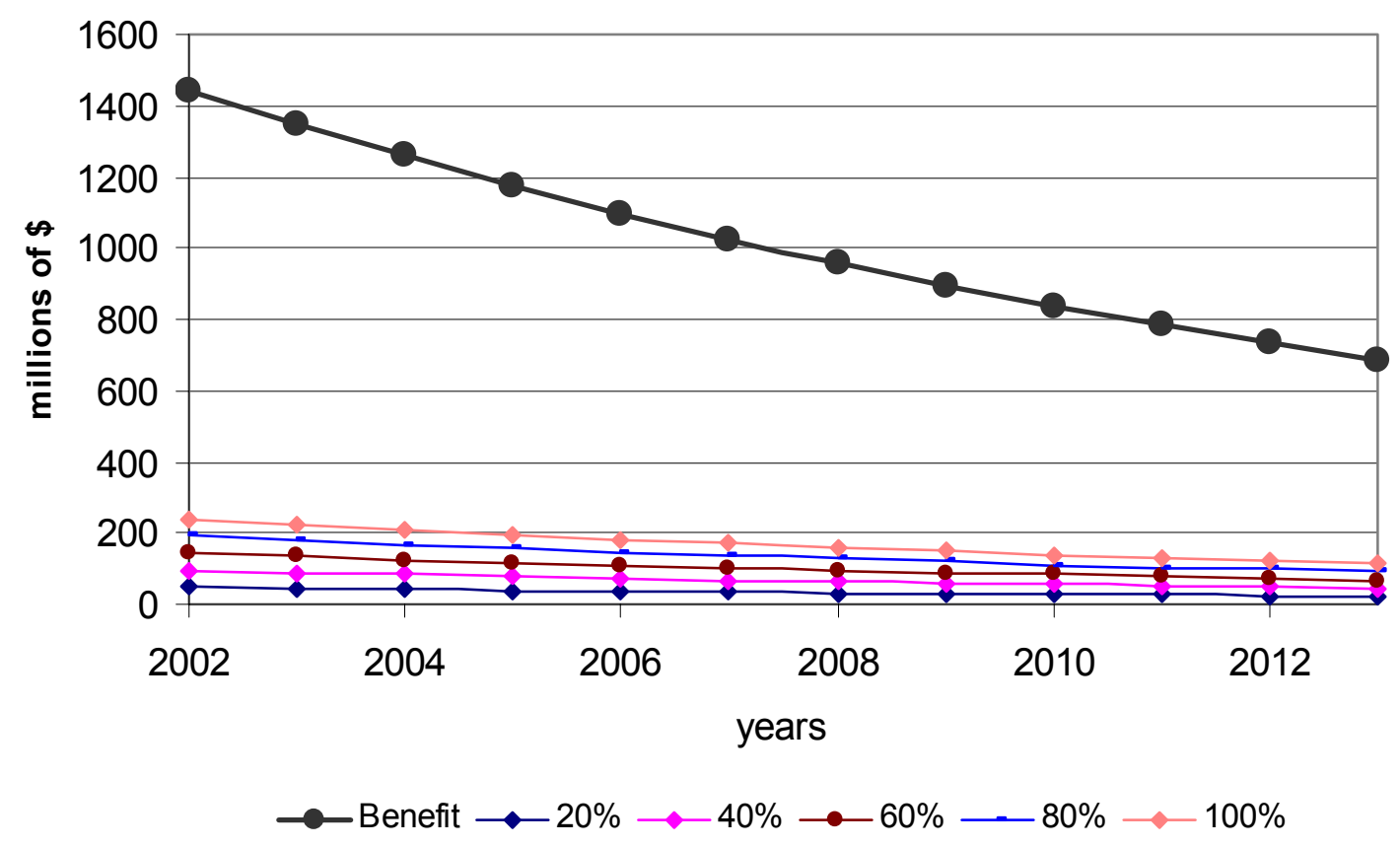

Figure 4.33 ORBP Present Worth of Benefits and Total Debt Service in 2002 using 2000 Dollars.

The results displayed in Figure 4.33 are consistent with the results of all three of the previous analyses. The higher the project's benefit-cost ratio, the more justification INDOT has for funding a project with GARVEE bonds. As previously stated, it is not beneficial to wait for a lower debt service while losing much more in user benefits. 
As discussed in the analyses of U.S. 31, SR 641 and I-69, incorporating inflation cost into the calculation of the PW of debt service increases the value of debt service as the amount issued increases over time (Figure 4.34). The avoidance of cost increases due to inflation is another financial advantage for executing the project sooner.
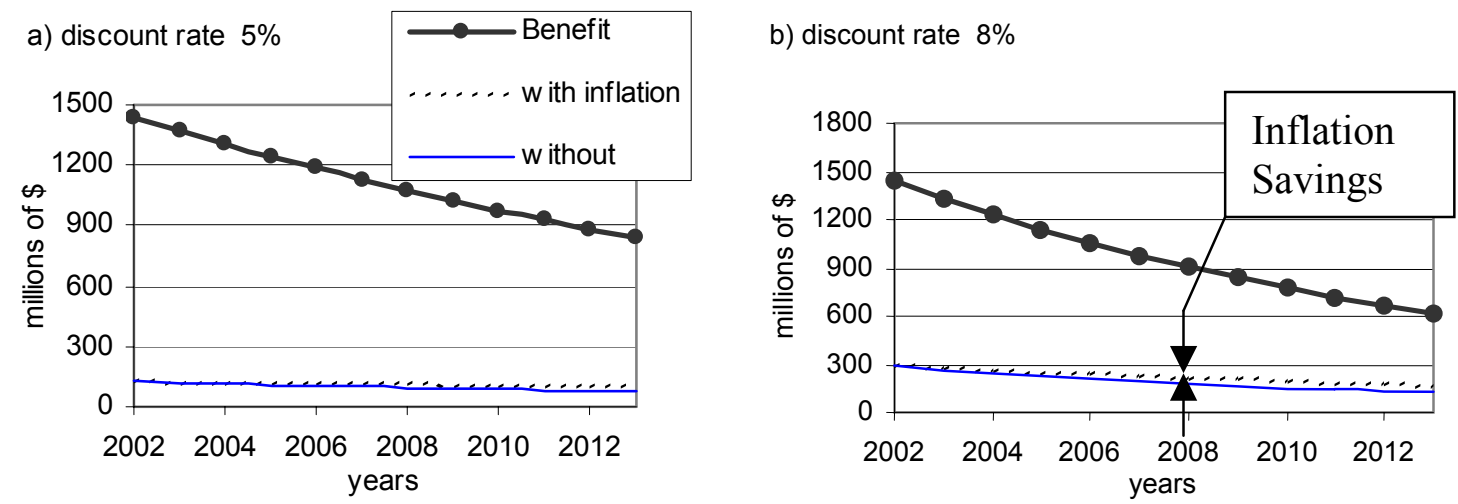

Figure 4.34 ORBP Discounted Benefit and PW of Debt Service in 2002 with Incorporated Inflation Factor.

As with U.S. 31, SR 641 and I-69 the results of this analysis show that it is feasible to use the GARVEE program as a financing technique for the ORBP project. The benefits associated with expediting the project can far outweigh the additional cost associated with debt financing.

\subsection{Transportation Infrastructure Finance and Innovation Act}

The Transportation Infrastructure Finance and Innovation Act (TIFIA) was authorized in 1998 as part of TEA-21. TIFIA was designed to provide assistance in the form of credit, rather than grants, to major transportation capital investments. When the program was first enacted into law, the federal government estimated that the TIFIA would provide up to $\$ 10.6$ billion in credit assistance for new transportation projects during the TEA-21 period (FY 1999-2003) at a maximum budget authority cost of $\$ 530$ million [FHWA, 1999]. Budget authority costs would cover the expected losses of the TIFIA portfolio associated with the provision of federal credit assistance. 
TIFIA established three new forms of federal assistance for eligible surface transportation projects under TEA-21: a loan, a loan guarantee, or a line of credit. Projects eligible for funding include highway and transit projects, intercity passenger rail and bus facilities, public-owned intermodal freight facilities, and border-crossing infrastructure.

Such large-scale projects often have their own revenue sources that can be used to help defray costs. However, due to their size and complexity, these major transportation investments may have trouble accessing the capital markets on their own. TIFIA's purpose is to fill the market gaps and to leverage additional non-federal sources by providing supplemental and subordinate capital. The Secretary of Transportation is responsible for implementation of the TIFIA program, with support from the U.S. DOT Credit Program Steering Committee [Streeter and George, 2001].

\subsubsection{Eligible Costs and Selection of Projects}

Various highway, transit, rail, and intermodal projects are eligible for credit assistance under TIFIA, and the credit assistance requirements refer mostly to eligible project costs, rather than the project itself.

The TIFIA, as codified under Title 23 of the U.S. Code 181, defines eligible project costs as expenses for the following activities:

- development (activities such as planning, feasibility and environmental studies, preliminary engineering and design, etc.),

- construction (property and equipment acquisition, environmental mitigation),

- financing (capitalized interest, cost of insurance, reserve funds).

Any expenses related to the application process for credit assistance are not eligible project costs. Each project must meet certain threshold criteria to qualify for the TIFIA program [FHWA, 2000]:

- The total eligible project cost should be at least $\$ 100$ million or 50 percent of the state's annual federal apportionment (whichever is less).

- The application form for TIFIA assistance should be submitted to the U.S. DOT. 
- The project should be included in the state's Transportation Plan and approved in the state's Transportation Improvement Program.

- The project should be repayable from dedicated revenue sources (fees, tolls, etc.).

- The project must receive public approval if private sponsorship is present.

In addition, TIFIA assistance cannot exceed 33 percent of the eligible costs of a project, which means that in all cases the federal government would act as a minor investor.

The U.S. DOT also requires each applicant to provide an investment grade credit rating opinion letter from at least one nationally recognized bond-rating agency. That means, the senior debt obligations of a project must meet the requirements to obtain the investment grade rating. The TIFIA borrowing is subordinate to this senior debt. The initial evaluation of applications is based on several assumptions, pending a feasibility study, record of decision (described later in this section), mix of project debt to equity, etc.

A rating agency must give its opinion on the default risk of the TIFIA credit instrument as well. The U.S. DOT uses the assessment of the default risk to revise its initial estimate of the budget authority needed to cover credit losses [FHWA, 1999c]. All TIFIA assistance is provided on a competitive basis. Figure 4. illustrates the application and review process. The time from the submission of a letter of interest until the actual disbursement of federal funds involves a long, multi-step process. Careful project selection and thorough preparation by the state to justify its eligibility are very important. 


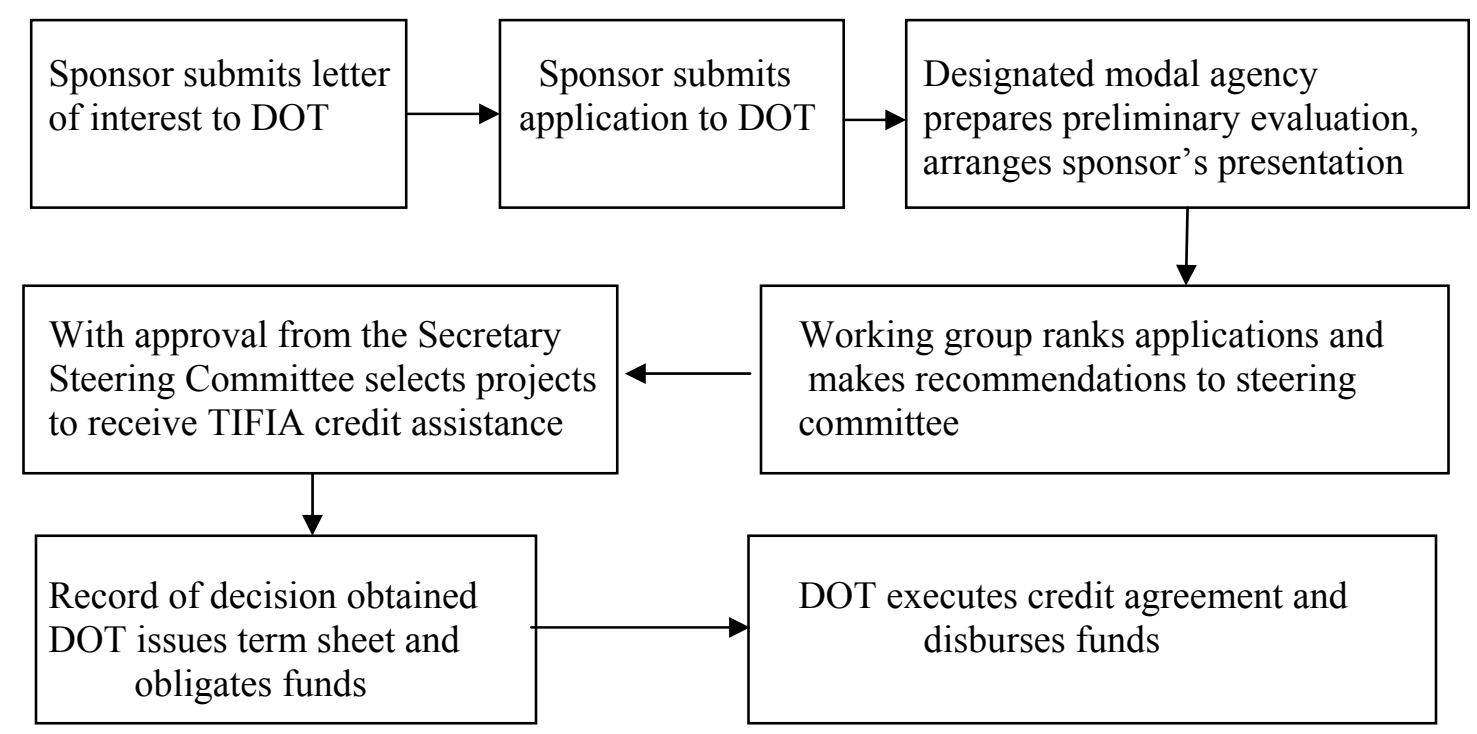

Figure 4.35 Application and Review Process for TIFIA Credit Assistance.

The Steering Committee's selections are based on several criteria, such as generated economic benefits, participation of private capital, use of new technologies, etc. Each criterion is assigned a certain weight that characterizes its significance in project selection (Figure 4.36). The criteria help to judge the projects and also clarify some ambiguous TIFIA provisions. The main criteria for a project to be selected are defined as its "national or regional significance", "environmental impact", and "participation of private capital", as shown in Figure 4.. The relative weights of these criteria reflect their close alignment with the objectives of the TIFIA program. 


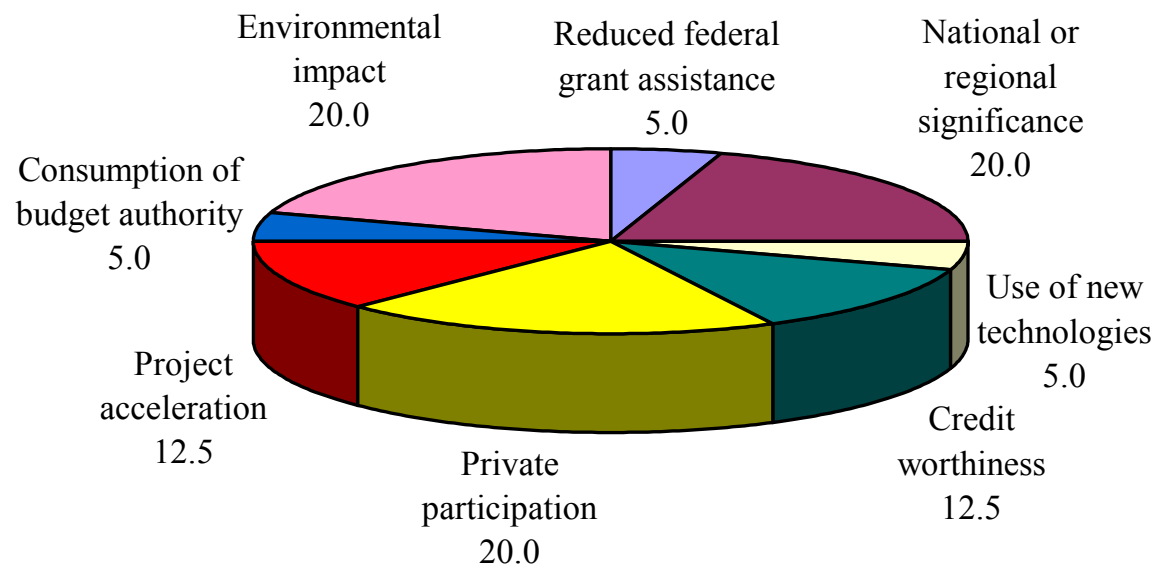

Figure 4.36 Assigned Weights for Selection Criteria (percentage amounts)

[FHWA, 1999c].

Submission of the required documentation to the U.S. DOT and the Steering Committee's selection of projects to receive TIFIA credit assistance do not conclude the process. The project sponsors are further required to obtain a record of decision, and the federal funds are disbursed only after the credit agreement is executed.

\subsubsection{TIFIA Credit Instruments}

Transportation infrastructure projects have different financing requirements at different stages of their development and operation. The various TIFIA credit instruments address the specific financing needs of projects during these different stages. There are four stages in the typical life-cycle of a transportation project:

\section{Development phase}

This is the earliest stage of the project and therefore can be described as the most speculative one. Engineering, financial, and environmental feasibility studies are conducted in this phase, and necessary approvals are secured as pre-conditions for construction. 


\section{Construction phase}

This phase requires the major part of the project's funds when it becomes critical to complete the work on time and within the budget. A project at this stage is subject to a different type of risks, i.e., cost overrun, environmental, performance, etc.

\section{Ramp-up phase}

After project completion, the establishment and adjustment of a revenue stream occurs in the ramp-up phase. It is difficult to project the revenue stream from transportation infrastructure users in the early years of operation.

\section{Project maturity phase}

This is the final phase of the project, when it must generate enough revenues over the long-term period to cover its capital and operating expenses. For large, capital-intensive projects, a period of 30 years or longer is often required to fully recover the initial investment [FHWA, 1997a].

TIFIA offers three credit instruments: direct federal loans, loan guarantees, and lines of credit, all of which are designed to address different financing needs throughout the project's life-cycle. FHWA suggests using different credit instruments during different project phases as shown in Figure 4.37. 


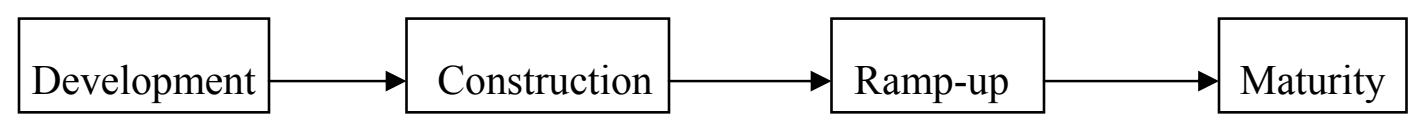

Standby Lines of Credit $\mid$

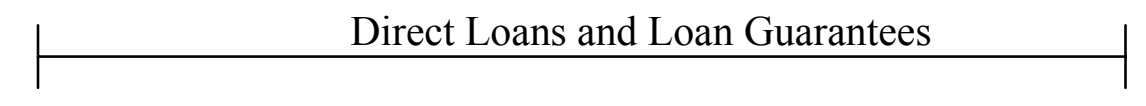

Figure 4.37 Potential Forms of Federal Credit Assistance Over a Project's Life.

\section{Direct Loan}

A debt obligation from the federal government to a project sponsor, providing long-term, fixed-rate permanent financing is a direct loan. Such loans may be issued for an amount up to 33 percent of the project's cost and can have a final maturity date no longer than 35 years after completion of construction. However, repayment may be deferred up to 10 years.

The interest rate is charged at the prevailing Treasury rate for similar maturity, and the interest accrues for any deferred payment. The specific terms and conditions of each loan can be negotiated between the federal government and the borrower. In the case of a default leading to bankruptcy, insolvency, or liquidation, the U.S. DOT must have a parity or co-equal claim on project assets with other investors [FHWA, 1999c]. The loan also can be prepaid at any time from excess revenues, without penalty.

\section{Loan Guarantee}

The loan guarantee offered by TIFIA is intended to facilitate senior project borrowing by guaranteeing a junior loan made by investors [FHWA, 1999c]. A junior loan (or subordinated loan) is a debt that is either unsecured or has a lower priority for repayment. A loan guarantee has basic features similar to a direct loan.

- The principal amount of the loan guarantee cannot exceed 33 percent of the project costs.

- The final maturity of the loan can be no longer than 35 years. 
- The interest rate can be negotiated between the lender and the borrower, and interest payments would be subject to federal income taxation.

- The guarantee loan would be secured with defined claims on project revenues.

Since it will receive a higher credit rating at a taxable yield level, a loan guarantee should help attract participation by investors that are capitalized well enough to absorb the liquidity and time horizon risks, but which historically have not been active in funding domestic infrastructure. Use of loan guarantees could encourage the development of a junior-lien private market over time.

\section{Standby Line of Credit}

In contrast to a direct loan and a loan guarantee, a standby line of credit is not meant to fund directly a project's construction costs. Under TIFIA, a standby line of credit represents an agreement between the federal government and the project sponsor to make one or more direct loans in the future if there is a need to fund revenue shortfalls. It is a supplementary instrument that can be used in the early years of operation (ramp-up phase in Figure 4.37).

There are some characteristics of a standby line of credit that separate it from the previous two credit instruments [FHWA, 1997a]:

- The line of credit can be assessed only after the project is complete and would remain open for ten next years.

- The borrower can draw down a maximum 20 percent of the line annually, and the total amount borrowed cannot exceed 33 percent of the total project costs).

- The interest rate is established at a rate equal to the 30 -year U.S. Treasury rate.

The federal line of credit can be very useful in this case. For example, when toll operation revenues are not sufficient to cover the debt service, the costs of extraordinary repair, operating and maintenance expenses, or capital expenditures. A credit instrument in the form of a line of credit secures federal support for the project, and in a way, it is a guarantee for a sponsor to participate in the project. Usually a loan agreement is made 
between the federal government and an authority that enter into an engagement of debt, rather that the state itself.

California used federal lines of credit as partial security on bond issuance for the construction of new toll road facilities in Orange County. Two separate bond issues were sold, each raising more than $\$ 1$ billion in 1993 and 1995. Congress approved $\$ 9.6$ million to fund the subsidy costs of a $\$ 120$ million federal line of credit for one of the projects (San Joaquin Hills Corridor Project) to help cover the debt service, if necessary, during the first five years of the toll road's operation. In this case, the federal government provided a $\$ 120$ million line of credit at a budgetary cost of $\$ 9.6$ million, which helped advance a $\$ 1.4$ billion transportation project [FHWA, 1997a]. A leverage ratio of 146 to 1 thus was created in terms of budgetary resources consumed for capital investment ( $\$ 1.4$ billion vs. \$9.6 million spent of federal funds).

\subsubsection{TIFIA Program Available Funding}

When the TIFIA program was enacted in 1998, the federal government estimated that it would provide up to $\$ 10.6$ billion in leveraged credit assistance for transportation projects during the next five years $(1999$ - 2003) from a total budget authority of $\$ 530$ million (Figure 4.). The amount available for credit assistance has been increasing since 1999, and in 2002 and 2003 a total of $\$ 5$ billion federal credit has been authorized under TEA-21.

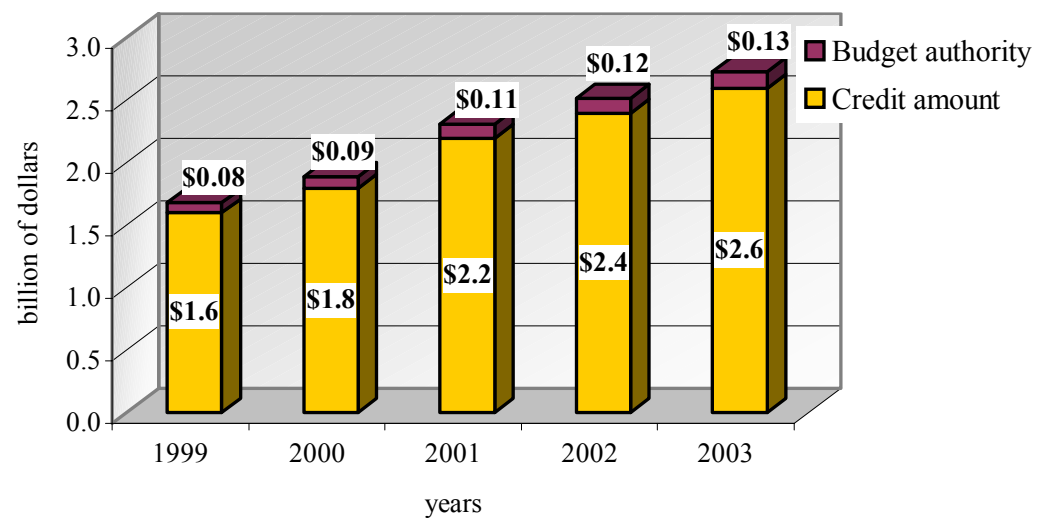

Figure 4.38 Credit Amount and Budget Authority Limitations. 
The Federal Credit Reform Act of 1990 requires a federal agency to set aside budgetary resources to cover the estimated subsidy cost of a credit instrument to the federal government. The estimate of subsidy cost represents the value of the government's estimated credit costs. Subsidy amounts vary from project to project, and from the list of selected TIFIA projects, it can be assumed that a rough estimate of the average subsidy rate is 6.77 percent [FHWA, 1999c].

TIFIA allows leveraging federal funds with a greater ratio than a federal-aid grant program. Assuming a $\$ 100$ million project, if the project is funded by a federal-aid grant program, federal funds cover 80 percent of the total cost, yielding a leverage ratio of $1.25: 1$. If the project were funded using TIFIA credit assistance, the federal share would be limited to 33 percent of the total cost. Assuming a budgetary cost of 6.77 percent of the total credit amount, it would result in $\$ 2.2$ million of budgetary subsidy cost, producing a $45: 1$ leverage ratio [FHWA, 1999c].

The actual progress of the program has not met the initial expectations of the federal government or the capital market in terms of utilization of authorized funds provided by TIFIA. Ten projects were selected in 1999 and 2000 but only one (The Tren Urbano of Puerto Rico) actually has received TIFIA disbursements [Streeter and George, 2001]. The remaining projects have not yet received TIFIA disbursements, which indicates that the TIFIA process is a time consuming one. There could be several factors affecting the implementation of TIFIA credit instruments, such as project readiness and the complexity of the TIFIA assistance approval process. Even though progress appears to be slow, a significant amount of work has been done by the federal government and project sponsors to implement the TIFIA program.

\subsubsection{Possible TIFIA Credit Assistance for INDOT Projects.}

Although TIFIA does not provide federal grants, it might be the lowest cost debt financing available for a project. According to the agreement between the U.S. Department of Treasury and the U.S. DOT, a project borrower is required to pay the prevailing rate for Treasury securities of a comparable maturity on the day that the loan agreement is executed, and repayment is expected by 35 years after a project's substantial 
completion. As in the case of the GARVEE program evaluation, four possible projects were considered in evaluating the fesibility of the TIFIA program.

\subsubsection{I-69 Evansville-to-Indianapolis}

The projected route between Evansville and Indianapolis has been designated by Congress as a high-priority corridor (Corridor 18) under Section 1105 of ISTEA. Approximately $\$ 63.4$ million of federal funding has been authorized for this project if the chosen route goes through Bloomington. About \$2.9 million of the authorized federal funds already has been spent on the EI study and preliminary design work. If the Evansville-Bloomington-Indianapolis is chosen, that would leave $\$ 60.5$ million of available federal funds for the I-69 project.

Due to the project's size ( $\$ 1.2$ billion) and its regional and national significance, the I-69 project can be eligible for TIFIA program funding, which means that a maximum of $\$ 396$ million (33 percent of project total cost) can be received as a federal loan under TIFIA.

The annual payments for the loan will depend on the maturity and the interest rate of the loan. A sensitivity analysis was done to show the relationship between the maturity term, interest rate, and annual payments as shown in Figure 4.39. The greater the maturity of the loan, the less the annual payment will be, and the higher the interest rate, the greater the annual debt service. 


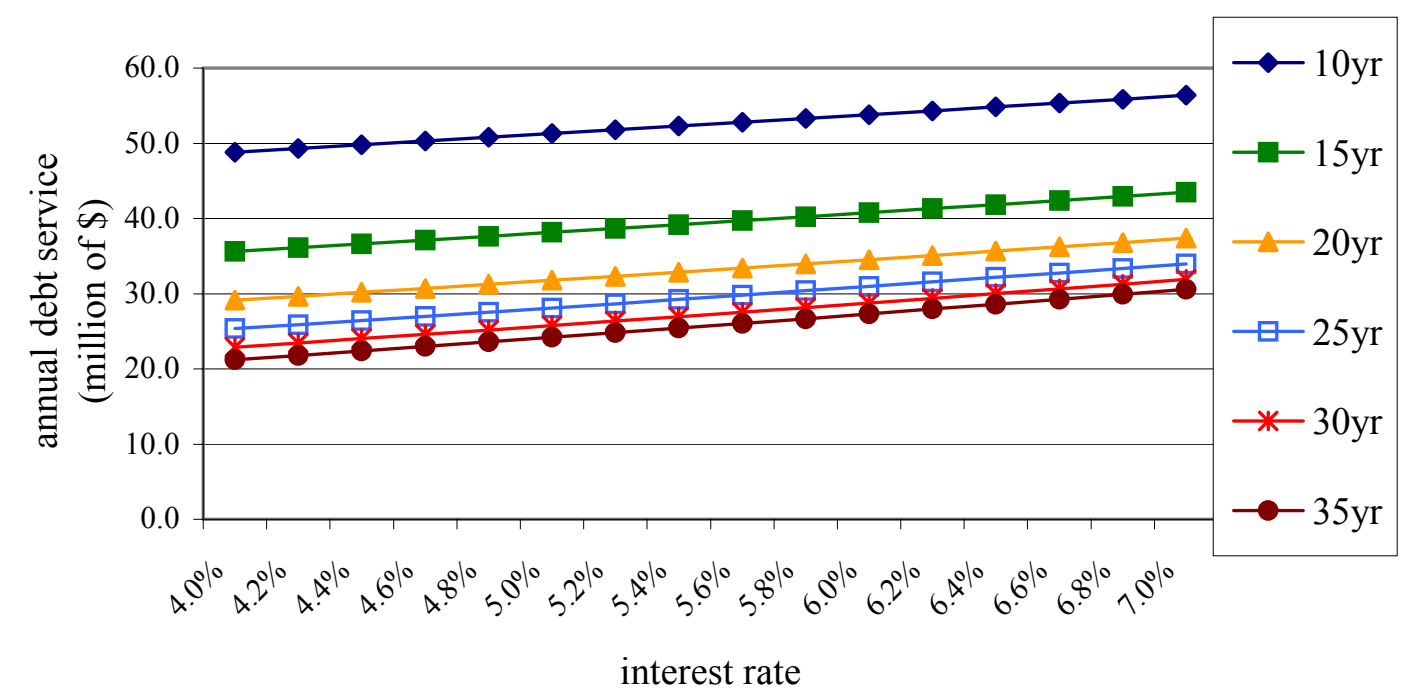

Figure 4.39 I-69 Annual Payments for Federal Loan with Different Terms and Interest Rates.

We assume that the project will start in 2005 and that the federal disbursement of $\$ 396$ million is received with the maximum term of 35 years and an interest rate of 5.4 percent. Interest will be deferred until 2008, when the construction is finished, so the assumed TIFIA payment structure for INDOT is as shown in Figure 4. .

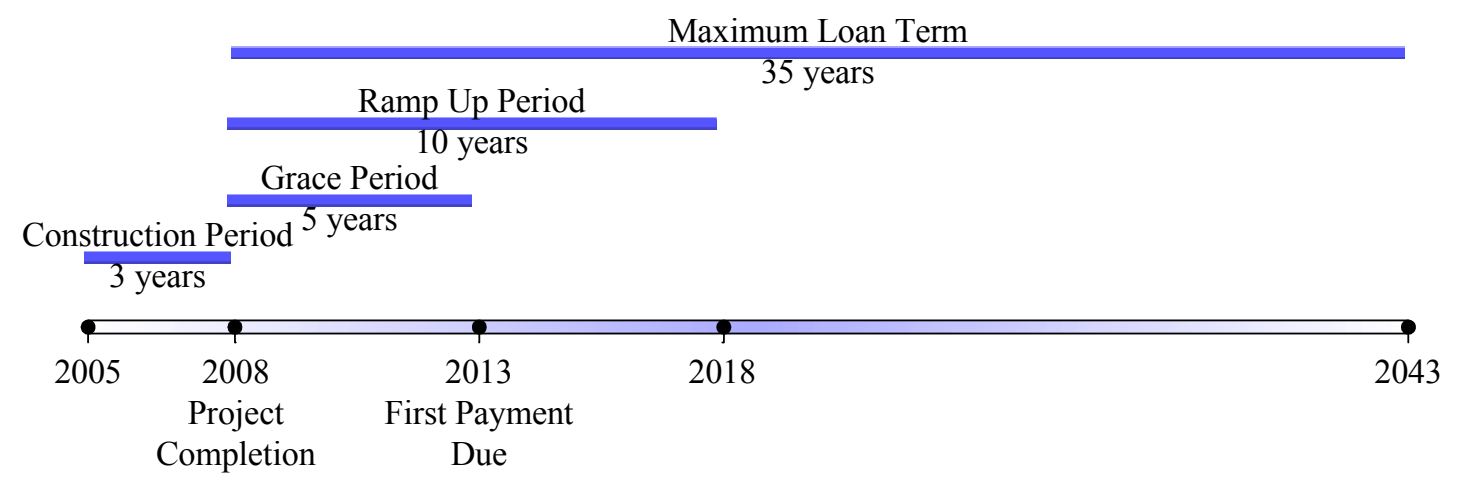

Figure 4.40 I-69 TIFIA Loan Payment Structure. 
The annual payments can be calculated by using the capital recovery formula as shown below:

$$
A=P * \frac{i(1+i)^{n}}{(1+i)^{n}-1}
$$

where

$\mathrm{A}=$ Annual Payment,

$\mathrm{P}=$ Loan Received,

$\mathrm{n}=$ Number of Years,

$\mathrm{i}=$ Interest Rate.

If interest is deferred until 2008 and INDOT would make its first payment in 2008, the annual payments for the 35-year period, with an interest rate of 5.4 percent, using Equation 7, would be $\$ 25.4$ million. Several possibilities for additional revenue exist for state or local governments to pay back the loan, including tax increment financing, toll revenue, and multi-county financing, as discussed below.

\section{Tax Increment Financing}

Tax Increment Financing (TIF) is an economic development tool that sets aside property tax revenue generated by a new project in a targeted area to pay for improvements associated with the project [Amt, 2000].

For publicly financed projects, TIF is popular because it raises revenue for development efforts without raising tax rates, offers incentives for businesses and developers, and is a revenue generator for municipal governments and regional development organizations.

The local government establishes the original pre-improvement property tax income from the TIF district. As investment in the district increases and the tax base improves, tax revenues beyond the original base level — the increment — are used to pay for improvements and subsidies. Some states also allow local sales tax and income tax revenues to fund the improvement.

Local governments have two options using TIF. The pay-as-you-go method is the more common and the slower of the two, relying on the tax base to increase as 
improvement is made. The other approach is to issue municipal bonds, whereby as investment increases in the district and the tax base improves, the increment is used to pay off the debt [Amt, 2000].

The INDOT I-69 Project includes nine Indiana counties. In these counties $\$ 1.26$ billion were collected from property tax in 2000 [ILSA, 1999]. If each of these counties would agree to use TIF, the increment of 2.1 percent of revenues from property tax would be needed each year in the 35-year period to pay off the federal loan, which is $\$ 25.4$ million annually in the given example (Table 4.7). Once the loan is retired, the taxes collected from the TIF area would be redirected to other needs within the counties.

Table 4.7 I-69 Revenue from Property Tax in Study Area in 2000.

\begin{tabular}{|l|r|r|r|r|r|r|r|}
\hline \multicolumn{1}{|c|}{ County } & $\begin{array}{c}\text { Population } \\
\text { (persons) }\end{array}$ & \multicolumn{1}{c|}{$\begin{array}{c}\text { Assessed } \\
\text { Value }(\$)\end{array}$} & \multicolumn{1}{c|}{$\begin{array}{c}\text { Net Levy } \\
(\$)\end{array}$} & $\begin{array}{c}\text { \% of } \\
\text { Total }\end{array}$ & $\begin{array}{c}\text { Needed } \\
\text { Net Levy }(\$)\end{array}$ & $\begin{array}{c}\text { Difference } \\
(\$)\end{array}$ & $\begin{array}{c}\text { Difference } \\
\text { per Capita } \\
(\$)\end{array}$ \\
\hline Daviess & 29,820 & $229,951,065$ & $16,328,535$ & $1.29 \%$ & $16,657,659$ & 329,124 & 11.04 \\
\hline Gibson & 32,500 & $322,118,515$ & $25,884,509$ & $2.05 \%$ & $26,406,246$ & 521,737 & 16.05 \\
\hline Greene & 33,157 & $194,182,745$ & $15,515,916$ & $1.23 \%$ & $15,828,660$ & 312,744 & 9.43 \\
\hline Johnson & 115,209 & $1,094,280,450$ & $78,896,904$ & $6.26 \%$ & $80,487,177$ & $1,590,273$ & 13.80 \\
\hline Marion & 860,454 & $9,082,244,677$ & $837,628,116$ & $66.42 \%$ & $854,511,633$ & $16,883,517$ & 19.62 \\
\hline Monroe & 120,563 & $913,542,592$ & $77,516,001$ & $6.15 \%$ & $79,078,440$ & $1,562,439$ & 12.96 \\
\hline Morgan & 66,689 & $504,522,510$ & $32,050,438$ & $2.54 \%$ & $32,696,458$ & 646,020 & 9.69 \\
\hline Pike & 12,837 & $172,269,820$ & $10,981,032$ & $0.87 \%$ & $11,202,369$ & 221,337 & 17.24 \\
\hline Vanderburgh & 171,922 & $1,426,723,040$ & $126,420,912$ & $10.03 \%$ & $128,969,095$ & $2,548,183$ & 14.82 \\
\hline Warrick & 52,383 & $618,183,445$ & $39,811,113$ & $3.16 \%$ & $40,613,559$ & 802,446 & 15.32 \\
\hline Total & $1,495,534$ & $14,558,018,859$ & $1,261,033,476$ & $100.00 \%$ & $1,286,451,296$ & $25,417,820$ & 17.00 \\
\hline
\end{tabular}

Toll

Toll financing is the most direct user fee. It can be easily approved from a political perspective because it does not cause additional tax increases or expenditures from the state or local governments. Toll road financing may require a public-private relationship for providing and operating a road. Therefore, many issues must be 
considered carefully, i.e., planning, contracting, tariff setting, risk sharing, concession period, etc. The toll rate can be determined as shown in Equation 8.

Toll Rate per VMT $=\frac{\text { Construction Cost }+ \text { Maintenance \& Operating Cost }+ \text { Interest }}{V M T}$

where

$\mathrm{VMT}=$ Vehicle Miles Traveled

The potential revenue collected from tolls depends on the projected traffic volume that the road will carry. A preliminary route location for I-69 considered a 150-mile section, consisting of parts of existing highways, and the annual average VMT on this proposed route in 1998 was estimated to be 1.032 billion miles [INDOT, 1998]. In order to estimate the VMT in 2008, a growth rate of two percent was applied in the present analysis; this rate was established using historical traffic data collected [INDOT, 1998]. The base VMT for "no-build" option was estimated to be 1.2 billion VMT in 2008. If the new highway were to open for operation in 2008, the base VMT would be assumed to increase an additional 30\% [BLA, 2001] and would come close to 1.54 billion VMT in 2008.

If it is assumed that the toll revenue would be used only for debt service payments, Equation 8 can be changed as shown below:

$$
\text { Toll Rate per VMT }=\frac{\text { Annual Debt Service }}{\text { Annual VMT }}
$$

In order to collect $\$ 25.4$ million each year for debt service payments, the average toll rate would have to be

$$
\frac{\$ 25.4 * 10^{6}}{1.54 * 10^{9} V M T}=\$ 0.016 \text { per mile. }
$$


As traffic volume is an uncertain parameter, a sensitivity analysis was performed to evaluate the effect of the estimated traffic on the minimum average toll rate as shown in Figure 4.41. While the consultants estimated that the construction of I-69 would cause a 30 percent increase in the existing VMT, toll rate computations were made using this rate to be as low as zero percent.

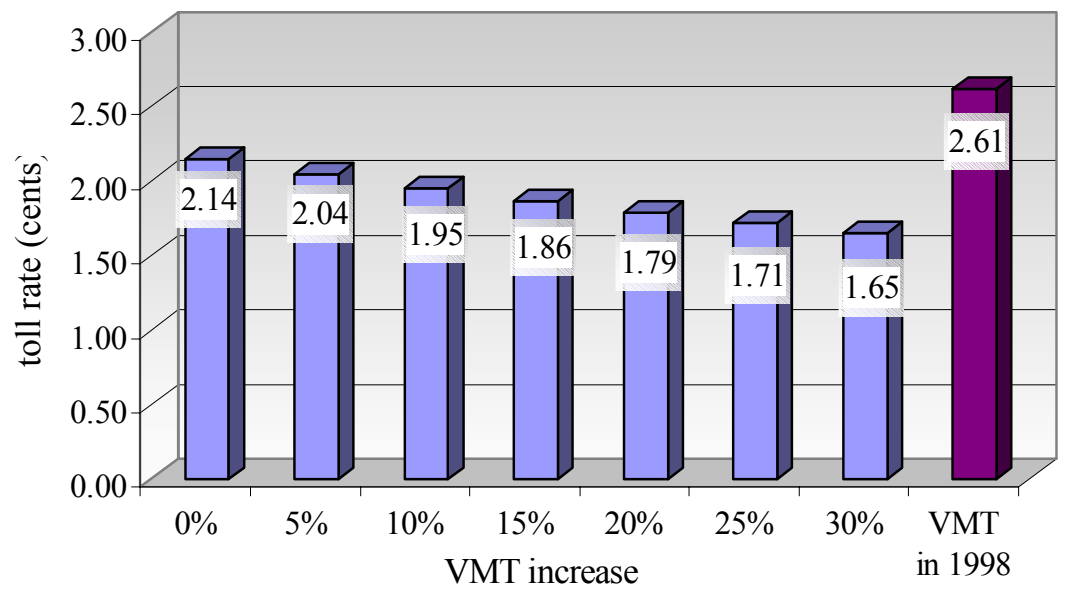

Figure 4.41 I-69 Estimated Average Toll Rate with Respect to Increase in VMT in 2008.

The analysis shows that the average toll rate needed most likely would not be greater than two cents per mile, if a VMT on the new I-69 would be close to estimated. Assuming the worst scenario of the VMT remaining in 1998 level, the average toll rate needed would be 2.61 cents to cover the annual debt service of $\$ 25.4$ million. The toll rate in Figure 4.41 would cover only about one-third of the project cost. However, toll can be used as a source of revenue, not only to cover the debt service but the entire project cost. In that case, annual cost for construction, maintenance and operation needs to be determined. As of 2001 the final EI study of the I-69 project was not yet completed and project costs including annual maintenance and operating costs could not be properly estimated. If INDOT would use toll as a source of revenue for the entire project, the minimum toll rate needed would still be reasonable and close to the average toll rate in 
the U.S., which is six cents per VMT [FHWA, 2001]. Thus, toll could be a realistic source of revenue for paying off the loan.

\section{Multi-county financing.}

Some counties may derive greater benefit than others from the project as the upgraded highway goes through their area. These counties may participate in the project financing by channeling a part of their revenues collected as taxes. One of the most appropriate taxes for this purpose appears to be the County Economic Development Tax (CEDIT), which is intended for economic development projects or public capital projects. CEDIT can be adopted along with the County Adjusted Gross Income Tax (CAGIT) or County Option Income Tax (COIT). It may be imposed at a tax rate up to 0.5 percent of taxable income. EDIT is collected by the Indiana Department of Revenue. In midsummer of each year the Department of Revenue, after consulting with the Indiana State Budget Agency, announces each county's certified distribution, which is the amount of income tax revenue the county will receive in the coming calendar year.

According to information from the Indiana Legislative Services Agency (ILSA), only three counties along the new highway alignment adopted CEDIT in 2000, collecting nearly $\$ 6.4$ million (Table 4.).

Table 4.8 I-69 CEDIT Rates and Revenues by County, 2000.

\begin{tabular}{|l|c|c|}
\hline \multicolumn{1}{|c|}{ County } & Rate & Revenue \\
\hline Gibson & $0.50 \%$ & $\$ 2,224,910$ \\
\hline Pike & $0.40 \%$ & $\$ 656,317$ \\
\hline Warrick & $0.35 \%$ & $\$ 3,498,355$ \\
\hline TOTAL & & $\$ 6,379,582$ \\
\hline
\end{tabular}

CEDIT was used in 55 Indiana counties in 1999 and 56 counties in 2000. The relatively small tax rate does not put a big burden on taxpayers but can generate significant amount for a local government's budget.

Other sources of revenue that local governments may use to finance the project are wheel tax, excise tax and surtax. These tax revenues are used to construct, reconstruct, repair, and maintain streets and roads. All Indiana counties collect motor 
vehicle excise tax but not all of them have adopted the surtax and wheel tax. Table 4.9 shows the revenues collected from these taxes in the counties in the study area in 1998.

Table 4.9 I-69 Motor Vehicle Excise Revenue by County, 1998 [ILSA, 1999].

\begin{tabular}{|l|r|c|c|r|}
\hline County & Excise Tax & Wheel Tax & Surtax & \multicolumn{1}{c|}{ Total } \\
\hline Daviess & $\$ 1,364,692$ & $\$ 45,757$ & $\$ 231,577$ & $\$ 1,642,026$ \\
\hline Gibson & $\$ 1,849,962$ & $\$ 23,334$ & $\$ 459,734$ & $\$ 2,333,030$ \\
\hline Greene & $\$ 1,682,080$ & - & - & $\$ 1,682,080$ \\
\hline Johnson & $\$ 7,359,522$ & - & - & $\$ 7,359,522$ \\
\hline Marion & $\$ 49,207,898$ & - & - & $\$ 49,207,898$ \\
\hline Monroe & $\$ 5,381,508$ & $\$ 44,427$ & $\$ 1,043,320$ & $\$ 6,469,255$ \\
\hline Morgan & $\$ 3,994,709$ & - & - & $\$ 3,994,709$ \\
\hline Pike & $\$ 682,840$ & - & - & $\$ 682,840$ \\
\hline Vanderburgh & $\$ 9,596,339$ & $\$ 109,835$ & $\$ 1,133,809$ & $\$ 10,839,983$ \\
\hline Warrick & $\$ 3,289,460$ & $\$ 82,558$ & $\$ 647,311$ & $\$ 4,019,329$ \\
\hline Total & $\$ 84,409,010$ & $\$ 305,911$ & $\$ 3,515,751$ & $\$ 88,230,672$ \\
\hline
\end{tabular}

The generated amount of revenue from motor vehicle excise tax, surtax and wheel tax are substantial. However, these funds are meant for local streets and roads. In order to use this money for the I-69 project, counties would need to be willing to devote these sources of revenue to the project. A county's participation in project financing may be established according to the benefits it would gain. Benefits can be represented in proportion of the length of I-69 going through a county's territory, the population along the proposed route, or the number of interchanges located in the county.

\subsubsection{SR 641 (Terre Haute Bypass)}

SR 641 was previously discussed to illustrate the advantages of using GARVEE bonds to finance transportation projects in Indiana. That analysis showed that if funding for SR 641 were delayed for 10 years, then INDOT could justify issuing GARVEE bonds to expedite the project. One might then ask, if SR 641 is a good candidate for GARVEE bond financing, would such a project be a good candidate for financing under TIFIA. 
The answer to the proceeding question is no. As outlined in Section 4.3.1, for a project to meet TIFIA guidelines its cost must be greater than $\$ 100$ million or $1 / 2$ of the state's federal apportionment. SR 641's estimated cost is \$79 million, falling \$21 million short of the $\$ 100$ million requirement. Indiana's federal apportionment is approximately $\$ 723$ million. This means the project's cost would have to be greater than $\$ 361.5$ million to be eligible for TIFIA.

\subsubsection{Louisville-Southern Indiana Ohio River Bridges Project}

The feasibility of using GARVEE bonds to finance the Louisville-Southern Indiana Ohio River Bridges Project (ORBP) was previously discussed. Alternatively, INDOT and KYTC might consider using TIFIA to partially fund the project. As previously discussed, TIFIA allows the borrower to obtain up to $1 / 3$ of the project's cost in direct loans, loan guarantees or standby lines of credit. For the direct loan option, the borrower is required to pay the prevailing rate for treasury securities of a comparable maturity on the day that the loan agreement is executed, and repayment is expected by 35 years after a project's substantial completion.

The details of ORBP were previously discussed in the GARVEE analysis, but the following few items warrant review for this analysis [Hazeltine, 2002]:

- ORBP is expected to have a total cost between $\$ 1.0$ and $\$ 1.8$ billion in year 2000 dollars. Again, we will assume total project cost to be the full $\$ 1.8$ billion.

- Indiana and Kentucky will jointly fund the project. Depending on the alternative selected Indiana's portion of the project's cost is expected to be between 30 and 40 percent. This analysis will assume that Indiana is responsible for the full 40 percent.

- If funding were not an issue, construction could begin as early as 2005 and would last from 10 to 12 years. We will assume that the construction phase lasts 10 years ending in 2015.

TIFIA requires that selected projects have either national or regional significance. While the ORBP does not carry national significance, arguments can possibly be made to support the project's regional significance. The details of this argument include: the project's ability to improve traffic congestion and safety in the metropolitan Louisville area, complete the circumferential highway system surrounding Louisville, and support 
the population and employment growth expected in eastern Jefferson County, Kentucky, and southeastern Clark County, Indiana [FHWA, INDOT \& KYTC, 2001].

Due to the project's size ( $\$ 1.8$ billion) and its regional significance, the ORBP can be eligible for TIFIA program funding, which means that a maximum of $\$ 600$ million (33 percent of project total cost) can be received as a federal loan under TIFIA.

Figure 4.42 presents the relationship between the maturity term, interest rate, and annual payments for the loan. As previously discussed, the greater the maturity of the loan, the less the annual payment will be, and the higher the interest rate, the greater the annual debt service. In this analysis, we will assume that repayment is deferred until completion of the project in 2015 (i.e. interest will be capitalized on the loan during the 10 years of construction).

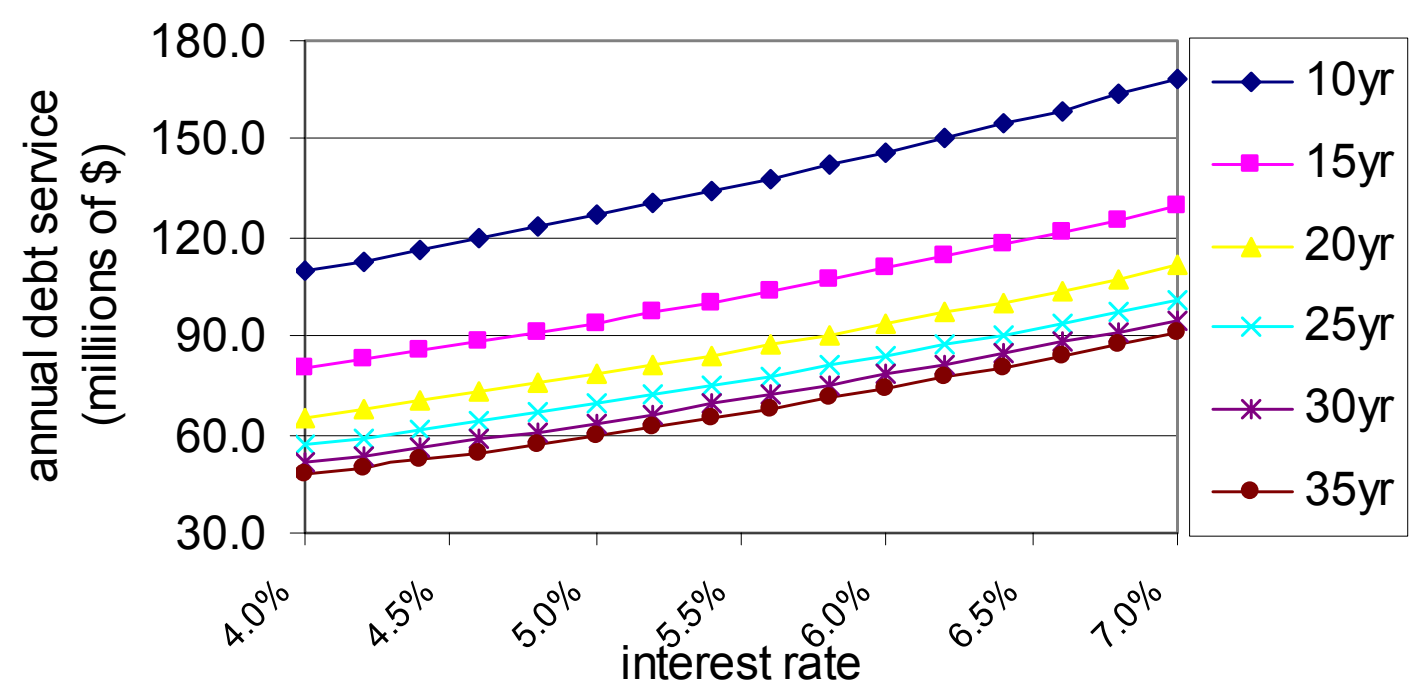

Figure 4.42 ORBP Annual Payments for Federal Loan with Different Terms and Interest Rates. 
Figure 4.43 shows the payment structure for this project under the following assumptions:

- Construction of the ORBP starts in 2005 and is completed in 2015.

- The federal disbursement of $\$ 600$ million is received with the maximum term of 35 years with an interest rate of 5.4 percent.

- Interest payments are deferred until 2015 when construction is completed.

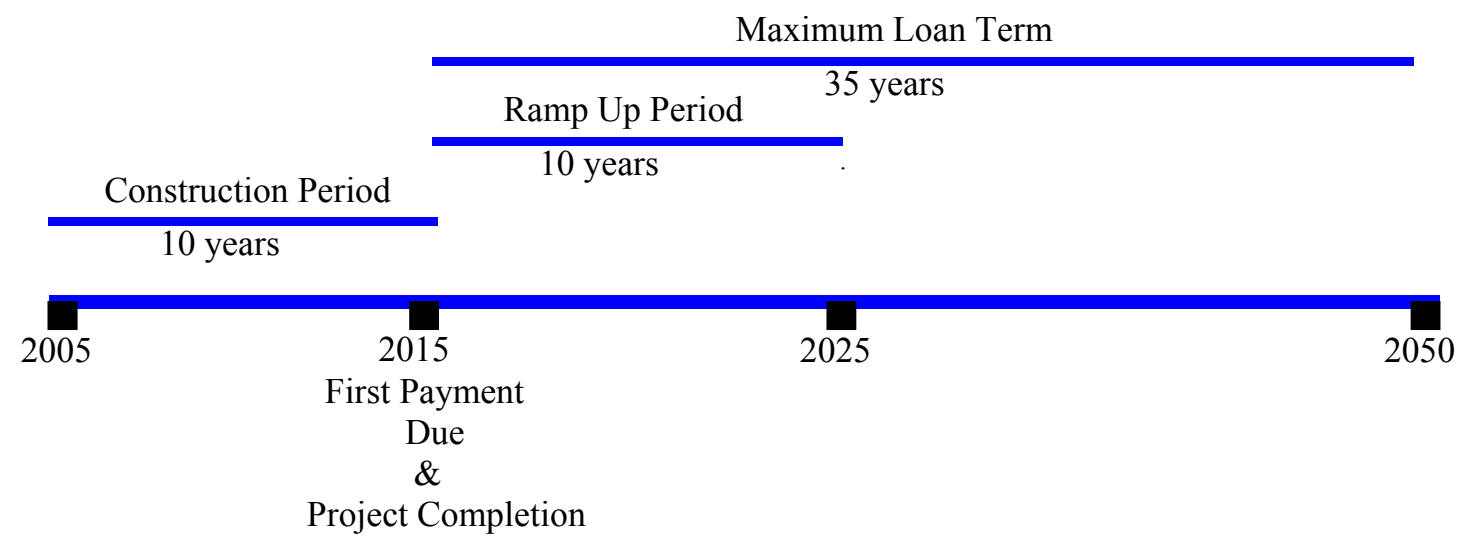

Figure 4.43 ORBP TIFIA Loan Payment Structure.

The capital recovery formula explained in the TIFIA analysis of I-69 can be used to determine the annual debt service payment for the ORBP. If interest payments were deferred until construction is completed in 2015 and INDOT and KYTC would make their first payment in 2015, the annual payments for the 35-year period, with an interest rate of 5.4 percent, would be $\$ 65.2$ million. Using our assumption that Indiana will be responsible for 40 percent of the project's cost, INDOT's portion of the annual debt service will be $\$ 26.08$ million. Indiana could use one of several possibilities to raise their portion of the annual debt service, including tax increment financing and multi-county financing. An additional option would be for INDOT and KYTC to use toll revenue to service their combined annual debt service of $\$ 65.2$ million. 


\section{Tax Increment Financing}

The potential for economic development in the vicinity of the ORBP makes TIF a possible alternative for generating revenue necessary to repay the loan. The bulk of the benefit of this project will be realized in Jefferson County, Kentucky and Clark County, Indiana. Floyd County, Indiana also stands to inherit significant benefit from the project due to its proximity to Louisville. This analysis will focus on Indiana's ability to raise its portion (40\%) of the annual debt service ( $\$ 26.08$ million), as a result we will look at the Clark and Floyd Counties to determine the feasibility of using TIF to repay the loan.

In 2000, Clark County and Floyd County collected approximately $\$ 113.3$ million in property tax [ILSA, 2000]. If each of these counties would agree to use TIF to pay for the ORBP, Clark County would be responsible for $58 \%$ of the annual debt service and Jefferson County the remaining $42 \%$. This means that for the debt service requirements to be met, Clark County's net levy would need to increase by $\$ 15.2$ million and Floyd County's net levy would need to increase by $\$ 10.9$ million for each of the remaining years after the project is completed (see Table 4.10).

Table 4.10 ORBP Revenue from Property Tax in Study Area, Fiscal Year 2000 [ILSA, 2000].

\begin{tabular}{|l|r|c|c|r|r|r|r|}
\hline \multicolumn{1}{|c|}{ County } & $\begin{array}{c}\text { Population } \\
\text { (persons) }\end{array}$ & $\begin{array}{c}\text { Assessed } \\
\text { Value }(\$)\end{array}$ & $\begin{array}{c}\text { Net Levy } \\
(\$)\end{array}$ & $\begin{array}{c}\% \text { of } \\
\text { Total }\end{array}$ & $\begin{array}{c}\text { Needed } \\
\text { Net Levy }(\$)\end{array}$ & $\begin{array}{c}\text { Difference } \\
(\$)\end{array}$ & $\begin{array}{c}\text { Difference } \\
\text { per Capita } \\
(\$)\end{array}$ \\
\hline Clark & 96,472 & $\$ 740,178,800$ & $\$ 66,128,739$ & $58 \%$ & $\$ 81,353,318$ & $\$ 15,224,579$ & $\$ 158$ \\
\hline Floyd & 70,823 & $\$ 589,201,398$ & $\$ 47,151,079$ & $42 \%$ & $\$ 58,006,500$ & $\$ 10,855,421$ & $\$ 153$ \\
\hline Total & 167,295 & $\$ 1,329,380,198$ & $\$ 113,279,818$ & $100 \%$ & $\$ 139,359,818$ & $\$ 26,080,000$ & $\$ 156$ \\
\hline
\end{tabular}

An increase of this magnitude resulting from development in the project area is unlikely, if possible at all. This conclusion is supported by the economic impacts section of the DEIS for the ORBP completed in November 2001. The DEIS estimates that the project's impact on state/local taxes will be between $\$ 8.1$ and $\$ 38.2$ million for a ten year period following the project's completion depending on the chosen alternative [FHWA, INDOT \& KYTC, 2001]. This is far short of the \$26.08 million needed to service Indiana's allocation of the debt on an annual basis. As a result we must conclude that 
TIF is not a feasible alternative to repay all of Indiana's portion of the debt associated with the ORBP.

\section{Multi-county financing.}

If the residents of Clark and Floyd Counties determine that the benefits of the project are great enough, the counties could participate in the project financing by channeling a part of their revenues collected as taxes. As discussed in the I-69 analysis, one of the most appropriate taxes for this purpose appears to be the County Economic Development Tax (CEDIT), which is intended for economic development projects or public capital projects. CEDIT has a relatively small tax rate that does not put a big burden on taxpayers but can generate a significant amount for a local government's budget.

According to information from the Indiana Legislative Services Agency, Floyd County adopted CEDIT in fiscal year 2000 while Clark County did not. Floyd County collected just over $\$ 4.1$ million in fiscal year 2000 with a tax rate of $0.30 \%$.

Clark and Floyd counties might also use a wheel tax, excise tax, and surtax to finance Indiana's portion of the ORBP. These tax revenues are used to construct, reconstruct, repair, and maintain streets and roads. While both Clark and Floyd counties collect motor vehicle excise tax (all counties collect this tax) neither county adopted a surtax or wheel tax.

Clark and Floyd Counties generated \$5.5 and \$4.4 million in fiscal year 2000, respectively, through vehicle excise tax. While the amount is substantial, it is highly unlikely that much of it can be used for ORBP. Alternately, Clark and Floyd Counties could follow the example of twenty-three other Indiana counties by levying a wheel tax and a surtax to raise additional revenue. In fiscal year 2000, individual counties collected wheel tax and surtax revenues ranging from $\$ 89,259$ to $\$ 13,676,937$ [ILSA, 2000]. These taxes could become a valuable new source of revenue to provide money for the ORBP, if the counties valued this project enough. 
Toll

As previously discussed, toll financing is the most direct user fee. It can be easily approved from a political perspective because it does not cause additional tax increases or expenditures from the state or local governments. The nature of the ORBP would make it relatively easy to operate newly constructed bridges across the Ohio River as Toll Bridges. The potential revenue collected from tolls depends on the projected traffic volumes that the bridges will carry.

The DEIS suggest that if a two bridge alternative is chosen, the best option would be to locate one in the downtown area and one in the East End [FHWA, INDOT \& KYTC, 2001]. Chapter 2 of the DEIS provides projections of vehicles crossing the Ohio River from 2000 to 2025. According to these estimates, the number of vehicles crossing the Ohio River per day in 2015 (when we estimate construction could be completed and repayment would begin) will be approximately 300,600. The three bridges currently located in downtown Louisville carried 244,000 vehicles per day across the river in 2000. These bridges have a combined capacity of approximately 265,000 vehicles per day [FHWA, INDOT \& KYTC, 2001]. Assuming that the three bridges in place will operate at capacity, we can deduce that a fourth bridge located in the downtown would need to carry at least 35,600 vehicles per day in 2015 increasing to 77,000 by 2025 .

Chapter 3 of the DEIS provides preliminary traffic projections for each of the four non-downtown corridors. If the Near East bridge alternative were selected, CTS estimates that in $2025,81,000$ vehicles per day would cross the bridge [FHWA, INDOT \& KYTC, 2001]. Using the 1.4 percent growth rate estimated in the DEIS, we can expect that in 2015 the Near East Bridge would carry approximately 70,500 vehicles per day.

Summing our estimates explained above, we estimate that in 2015 the two new bridges would carry a combined volume of about 106,100 vehicles per day. If we assumed that the toll revenue would be used only for debt service payments the toll rate per vehicle can be calculated as follows:

Toll Rate per Vehicle Crossing $=\frac{\text { Annual Debt Service }}{\# \text { Vehicle Crossings/ Year }}$ 
Previously we determined that $\$ 65.2$ million per year is needed to service the debt if interest payments are capitalized until construction is completed in 2015, repayment is stretched over the maximum of 35 years, and the interest rate is 5.4 percent. In this case the toll rate per vehicle crossing will need to be a minimum of $\$ 1.61$ to collect the $\$ 65.2$ million need per year.

$$
\frac{\$ 65.2 * 10^{6}}{(106,100 \text { cros } \sin g s / \text { day })^{*}(365 \text { days } / \text { year })}=\$ 1.61 \text { per } \text { crossing }
$$

As traffic volume is an uncertain parameter, a sensitivity analysis was performed to evaluate the effect of the estimated traffic on the minimum average toll rate as shown in Figure 4.44. The estimated traffic volume of 106,100 crossings per day was varied between -30 and +30 percent.

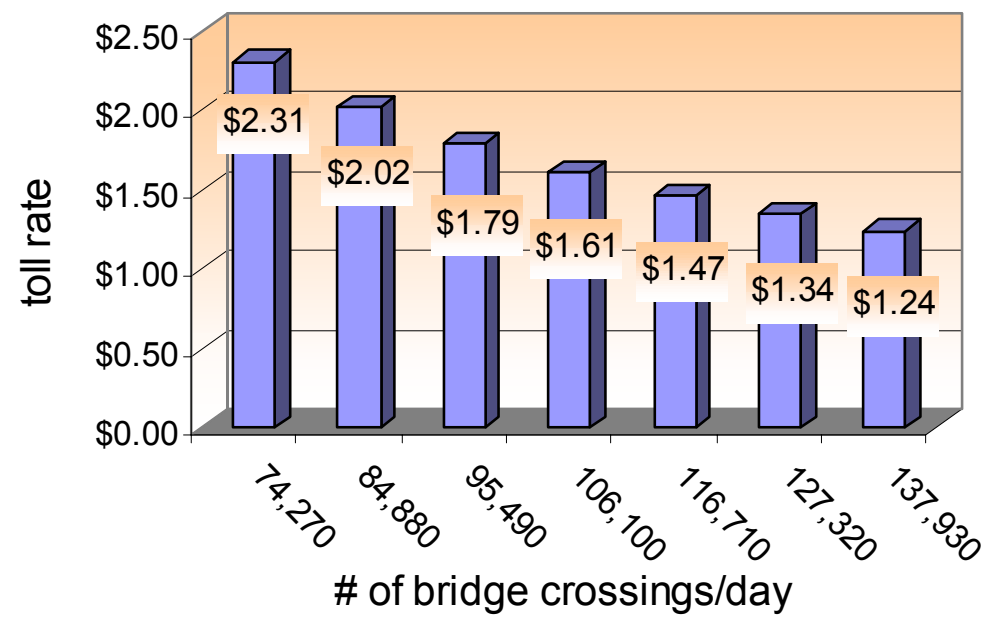

Figure 4.44 ORBP Estimated Toll Rate with Respect to Estimated \# of Daily Bridge Crossings in 2015.

The analysis shows that the toll rate needed to cover the annual debt service would most likely be in the range of $\$ 1.24$ to $\$ 2.31$. This range indicates two things: (1) toll collection is a feasible source for revenue to fund the debt service of the project associated with TIFIA, (2) toll rates would need to be excessive to cover the entire 
project cost. To fund the entire project, the toll rates would need to be approximately three times higher.

If INDOT and KYTC decided to charge a toll on the three existing bridges in addition to the two new bridges, individual toll rates could be reduced significantly and demand would likely be more evenly spread over the bridges. Using our 2015 demand estimates, a minimum toll rate of about $\$ 0.58$ per crossing would need to be charged to cover the $\$ 65.2$ million annual debt service associated with the TIFIA loan if a toll were charged on all five bridges. Similarly, if INDOT and KYTC chose to fund the entire project ( $\$ 1.8$ billion) with toll revenue collected from all five bridges, the minimum toll rate would need to be approximately $\$ 1.44$ per crossing.

\subsubsection{U.S.31 Corridor Improvement Project}

Previously we discussed the option of using GARVEE bonds to finance the U.S. 31, Corridor Improvement Project from Indianapolis to South Bend. Our analysis showed this project might be a good fit for GARVEE bond financing. Interestingly enough, it appears that the U.S. 31 project may also be a good fit for financing under TIFIA.

The U.S. 31 corridor is on the National Highway System and provides a highcapacity connection from the Indianapolis metropolitan area to northern Indiana and central Michigan. It serves a critical function as a freight route for trucks traveling to destinations within and outside of the corridor. Indiana ranks sixth in the United States for annual truck shipments based on ton-miles. It is important to note that U.S 31 provides a direct connection between northern Indiana and Southern Michigan, a route not served by the Interstate System [Parsons Transportation Group, 2000]. Consequently, it is reasonable to expect that the project meets TIFIA's requirement of regional significance.

If approved, the project would be eligible for a maximum of $\$ 400$ million (33 percent of project total cost of $\$ 1.2$ billion) as a federal loan, loan guarantee, or standby line of credit under TIFIA. Assuming INDOT is granted the loan, the annual debt service would depend on the maturity and the interest rate of the loan, as shown in Figure 4.45. 


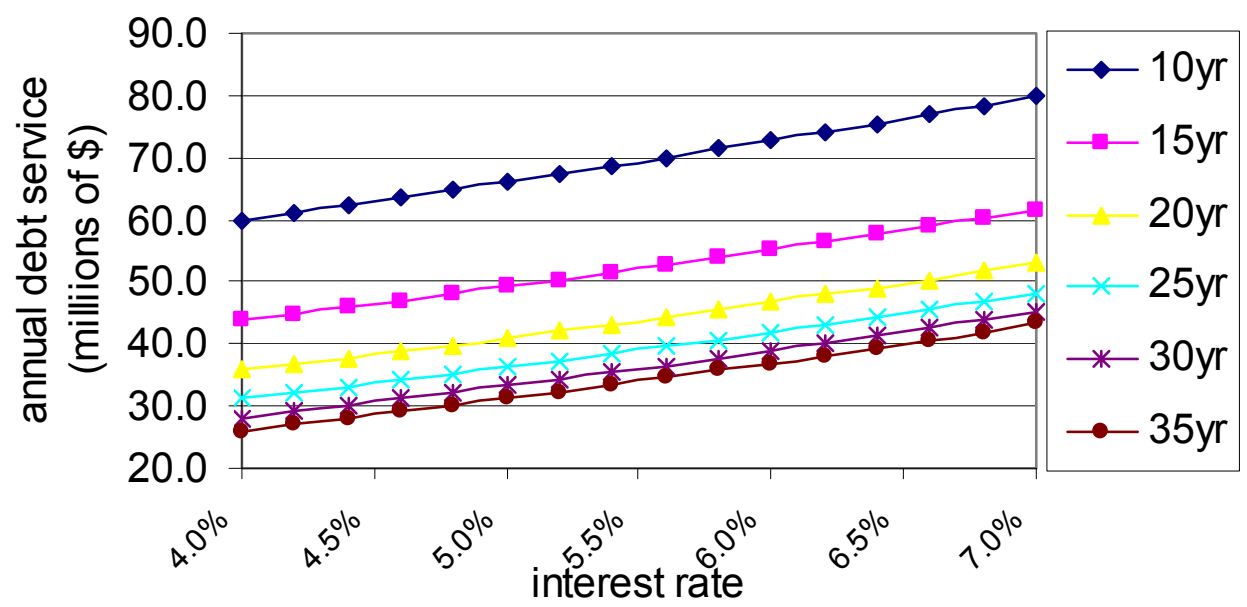

Figure 4.45 U.S 31 Annual Payments for Federal Loan with Different Terms and Interest Rates.

Figure 4.46 shows the payment structure for this project under the following assumptions:

- Construction of the U.S. 31 Corridor Improvement Project starts in 2005.

- The federal disbursement of $\$ 400$ million is received with the maximum term of 35 years with an interest rate of 5.4 percent.

- Interest payments are deferred until 2010 when construction is completed.

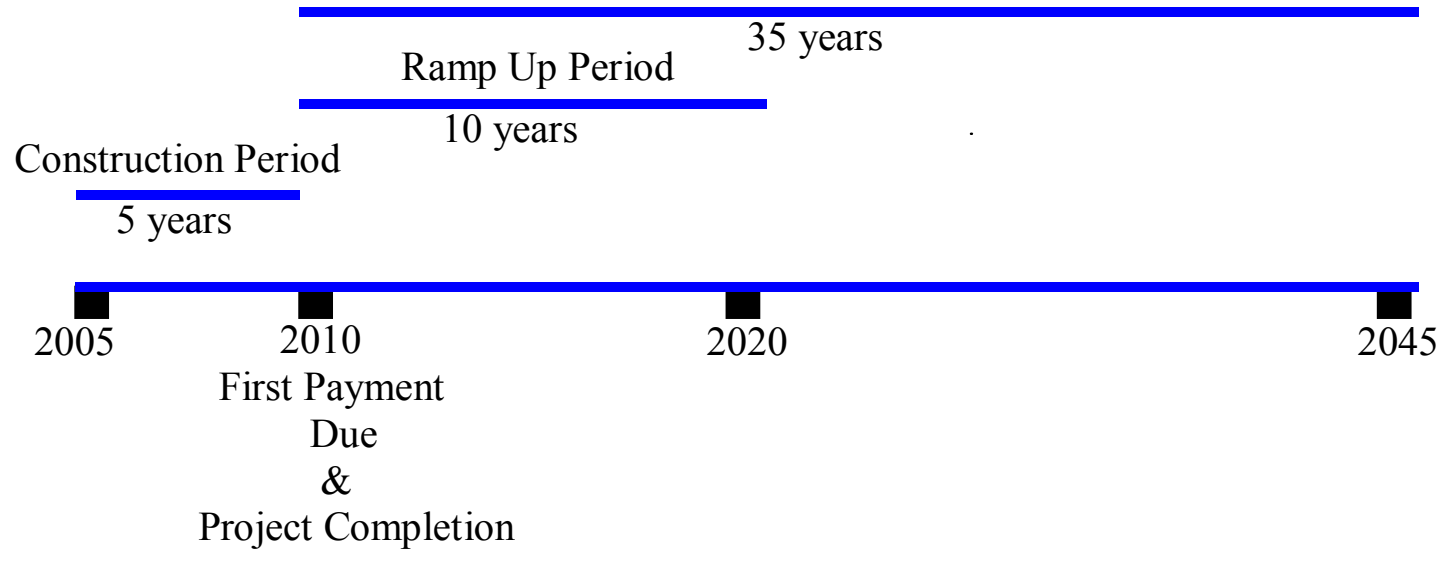

Maximum Loan Term

Figure 4.46 U.S 31 TIFIA Loan Payment Structure. 
If interest payments were capitalized until construction is completed in 2010 and INDOT makes the first payment in 2010, the annual payments for the 35-year period, with an interest rate of 5.4 percent, would be $\$ 33.4$ million. Under TIFIA, Indiana could use one of (or a combination of) several methods to raise the annual debt service, including tax increment financing, tolls, and multi-county financing. Each of these options has been discussed for other case studies, but we will now apply them to the U.S. 31 Corridor Improvement Project.

\section{Tax Increment Financing}

The potential for additional economic development along the U.S 31 corridor makes TIF a possible alternative for payment of the annual debt service. Chapter 7 of INDOT's 2000-2025 Long Range Plan says that, "the economic evaluation (of U.S. 31) found the freeway upgrade would increase the market area for businesses along the U.S 31 corridor and improve travel conditions thereby lowering the cost of transportation [INDOT, 2001b]." The improved transportation access was estimated to attract approximately 200 new jobs in the industries of motor vehicles and parts, metal products, rubber and plastics, electrical equipment, and retail trade. Overall, $\$ 1.3$ billion in economic impacts were identified over the analysis period [INDOT, 2001b].

The U.S. 31 corridor between Indianapolis and South Bend stretches through 7 Indiana counties. In fiscal year 2000, these counties collected approximately $\$ 581.8$ million in property tax [ISLA, 2000]. If each of these counties would agree to use TIF, the increment of 5.7 percent of revenues from property tax would be needed each year in the 35-year period to pay off the federal loan, which is $\$ 33.4$ million annually in the given example (Table 4.11). Once the loan is retired, the taxes collected from the TIF area would be redirected to other needs within the counties.

Table 4.11 U.S. 31 Revenue from Property Tax in Study Area, Fiscal Year 2000.

\begin{tabular}{|c|c|c|c|c|c|c|c|}
\hline County & $\begin{array}{c}\text { Population } \\
\text { (persons) }\end{array}$ & $\begin{array}{c}\text { Assessed Value } \\
\text { (\$) }\end{array}$ & Net Levy (\$) & $\%$ of Total & $\begin{array}{c}\text { Needed Net Levy } \\
\text { (\$) }\end{array}$ & Difference (\$) & $\begin{array}{c}\text { Difference Per } \\
\text { Capita (\$) }\end{array}$ \\
\hline Fulton & 20,511 & $192,333,780$ & $13,792,294$ & $2 \%$ & $14,584,145$ & 791,851 & 39 \\
\hline Hamilton & 182,740 & $\begin{array}{l}2,579,848,474 \\
\end{array}$ & $\$ 197,287,168$ & $34 \%$ & $208,613,928$ & $\$ 11,326,760$ & 62 \\
\hline Howard & 84,964 & $\$ 1,044,433,064$ & $77,944,253$ & $13 \%$ & $82,419,231$ & $4,474,978$ & 53 \\
\hline Marshall & 45,128 & $441,412,210$ & $31,757,621$ & $5 \%$ & $33,580,907$ & $1,823,286$ & 40 \\
\hline Miami & 36,082 & $232,823,880$ & $18,168,096$ & $3 \%$ & $19,211,173$ & $1,043,077$ & 29 \\
\hline St. Joseph & 265,559 & $\$ 1,924,412,000$ & $\$ 231,639,162$ & $40 \%$ & $244,938,157$ & $\$ 13,298,995$ & 50 \\
\hline Tipton & 16,577 & $158,076,164$ & \$ $11,165,726$ & $2 \%$ & $11,806,779$ & 641,053 & 39 \\
\hline Total & 651,561 & $6,573,339,572$ & $581,754,320$ & $100 \%$ & $615,154,320$ & $\$ 33,400,000$ & 51 \\
\hline
\end{tabular}


Toll

Mandated by the Indiana General Assembly, the Indiana Transportation Finance Authority conducted a study in 1999 to examine the feasibility of constructing a new toll road from Indianapolis to South Bend. The study concluded that anticipated toll revenues would not be sufficient to pay the costs associated with the design, construction, maintenance and operating expenses, and meeting debt service requirements of the roadway [INDOT, 2001b].

While the U.S. 31 Corridor Improvement Project may not be supported entirely by toll revenue, it may be possible to support a portion of the project's cost with toll revenue. In this case study we must determine if toll revenue would be sufficient to cover the annual debt service associated with a loan approved by TIFIA. Previously we determined that the maximum loan that could be awarded under TIFIA for this project would be $\$ 400$ million. If the 35-year period of repayment is used with an interest rate of $5.4 \%$, the annual debt service for this loan would be $\$ 33.4$ million.

The potential revenue collected from tolls depends on the projected traffic volume that the road will carry. The section of U.S. 31 under consideration for upgrade to freeway design standards spans approximately 122 miles. An estimate of the annual average VMT on this route was obtained using AADT counts for each of the counties in the corridor [INDOT, 2002b]. We estimate that this corridor handles approximately 952.3 million vehicle miles per year (see Appendix A).

Using the methodology outlined in the TIFIA analysis of I-69, the minimum toll rate per vehicle mile traveled can be calculated. If the $\$ 33.4$ million estimate of annual debt service holds true and the toll revenue is used only for debt service, the minimum toll rate would have to be

$$
\frac{\$ 33.4 * 10^{6}}{952.3 \times 10^{6} V M T}=3.5 \text { cents per mile. }
$$

As traffic volume is an uncertain parameter, a sensitivity analysis was performed to evaluate the effect of the estimated traffic on the minimum toll rate as shown in Figure 
4.47. The estimated annual VMT of 952.3 million was varied between -30 and +30 percent.

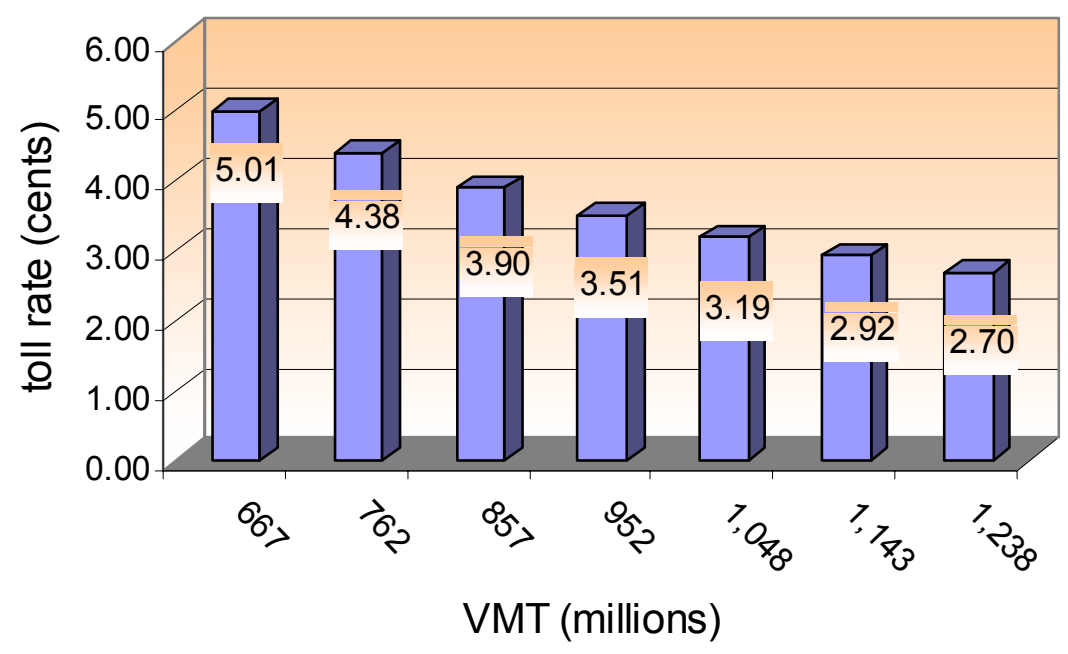

Figure 4.47 U.S. 31 Estimated Average Toll Rate with Respect to Varying VMT.

The analysis shows that the minimum toll rate needed would most likely be in the range of 2.5 to 5.0 cents per mile. Assuming the worst scenario of the VMT (VMT $=$ 667 million) the toll rate needed would be 5.01 cents/mile to cover the annual debt service of $\$ 33.4$ million. The preceding analysis shows that if INDOT were to use toll collection as a source of revenue for the annual debt service under TIFIA, the toll rate could be kept close to the average toll rate in the U.S., which is six cents per VMT [FHWA, 2001]. Thus, toll could be a realistic source of revenue for paying off the loan.

\section{Multi-county financing.}

As explained in the TIFIA analysis of I-69, some counties may derive greater benefit than others from the project as the upgraded highway goes through their area. These counties may participate in the project financing by channeling a part of their revenues collected as taxes. An appropriate source for this purpose can be the County Economic Development Tax (CEDIT), which is intended for economic development projects or public capital projects. According to information from the Indiana Legislative Services Agency, five of seven counties along the corridor had CEDIT in fiscal year 2000 , collecting nearly $\$ 14.1$ million (Table 4.12 ). 
Table 4.12 U.S. 31 CEDIT Rates and Revenues by County, Fiscal Year 2000

[ILSA, 2000].

\begin{tabular}{|l|c|l|}
\hline \multicolumn{1}{|c|}{ County } & Rate & \multicolumn{1}{c|}{ Revenue } \\
\hline Fulton & $0.18 \%$ & $\$ 428,580$ \\
\hline Howard & $0.20 \%$ & $\$ 3,156,109$ \\
\hline Miami & $0.25 \%$ & $\$ 1,060,261$ \\
\hline St. Joseph & $0.20 \%$ & $\$ 8,717,424$ \\
\hline Tipton & $0.25 \%$ & $\$ 711,982$ \\
\hline TOTAL & & $\$ 14,074,356$ \\
\hline
\end{tabular}

Other sources of revenue that local governments may use to finance the project are wheel tax, excise tax and surtax. Table 4.13 shows the revenues collected from these taxes in the counties along the U.S. 31 corridor in fiscal year 2000.

Table 4.13 U.S. 31 Motor Vehicle Excise Revenue by County, Fiscal Year 2000

[ILSA, 2000].

\begin{tabular}{|l|r|c|c|r|}
\hline County & \multicolumn{1}{|c|}{ Excise Tax } & Wheel Tax & Surtax & \multicolumn{1}{c|}{ Total } \\
\hline Fulton & $\$ 1,241,600$ & - & - & $\$ 1,241,600$ \\
\hline Hamilton & $\$ 16,085,395$ & - & - & $\$ 16,085,395$ \\
\hline Howard & $\$ 6,252,366$ & $\$ 69,729$ & $\$ 1,496,223$ & $\$ 7,818,318$ \\
\hline Marshall & $\$ 2,609,474$ & - & - & $\$ 2,609,474$ \\
\hline Miami & $\$ 2,133,858$ & - & - & $\$ 2,133,858$ \\
\hline St. Joseph & $\$ 15,032,170$ & - & - & $\$ 15,032,170$ \\
\hline Tipton & $\$ 1,279,037$ & - & - & $\$ 1,279,037$ \\
\hline Total & $\$ 44,633,900$ & $\$ 69,729$ & $\$ 1,496,223$ & $\$ 46,199,852$ \\
\hline
\end{tabular}

The generated amount of revenue from motor vehicle excise tax, surtax and wheel tax are substantial. In order to use this money for the U.S. 31 corridor improvement project, these counties would need to be willing to devote a portion of these sources of 
revenue to the project. A county's participation in project financing may be established according to the benefits it would gain. Benefits can be represented in proportion by the length of U.S. 31 going through a county's territory and the population in each of the counties in the corridor.

\subsubsection{Pros and Cons of TIFIA Program}

TIFIA is a relatively new program under TEA-21 that provides an innovative way to finance major transportation projects of national or regional significance. The TIFIA program brings the following financing benefits.

- It provides a significant funding source (33 percent of total project cost) in the form of credit instruments, thereby accelerating a project's execution.

- TIFIA cash flow subordination, debt service grace periods, low interest costs, and extended repayment terms can enhance senior project debt ratings [Streeter and George, 2001].

- The flexible repayment provisions can be extended up to 35 years.

- The interest and principal repayments may be deferred up to 10 years.

- The financing is subordinate to the project's senior debt so it does not have to meet "senior debt" criteria. The senior debt of the project being financed must have an investment grade rating from one of the major bond rating agencies.

- TIFIA does not require a reserve fund nor does it require a multiple of coverage over the debt service.

- Any government or private sector entity may be a project sponsor and submit TIFIA application. The U.S. DOT may not withhold other federal funds owed to a state if a TIFIA project defaults.

As for any other credit instrument, the TIFIA program carries some risks and financing disadvantages.

- TIFIA-provided credit instruments can be applied to limited types of projects and the program involves a complex process of document preparation. 
- The TIFIA program is not a grant and the total cost of a project increases due to the additional cost of interest payments.

- Interest on TIFIA loans is taxable, and the interest rates tend to be higher than on tax-exempt debt.

- Project finance risks are not eliminated by TIFIA assistance.

- TIFIA loan guarantees and lines of credit may delay, but will not prevent, a downgrade of senior project debt in cases where the project cash flows are subject to long-term financial imbalance [Streeter and George, 2001].

The TIFIA program creates an opportunity for federal funds to be leveraged at a higher ratio in terms of the amount consumed for capital projects, but from the state's perspective, it does not provide an additional source of funding. It is a technique that allows the state to receive a part of the amount needed for realization of the project sooner than otherwise, but it must be repaid from non-federal sources.

\subsection{State Infrastructure Bank}

The State Infrastructure Bank (SIB) is a revolving fund that can offer loans and non-grant forms of credit assistance to public and private sponsors of highway construction and transit capital projects. The National Highway System (NHS) Designation Act of 1995 authorized the U.S. DOT to establish the SIB pilot program, by which participating states could use some of their federal highway and transit grants to capitalize a revolving loan fund [FHWA, 1999b].

The purpose of the pilot program was to attract new funding into transportation and to encourage innovative approaches to transportation problems, thus accelerating the execution of transportation infrastructure projects. The NHS Act provided that each designated state can transfer up to 10 percent of certain federal dollars, match those funds with state funds, and deposit them into SIB. Thirty-nine states were approved to use federal funds to capitalize SIBs [Marx, 2000].

TEA-21 created a new SIB program implemented in only four states (California, Florida, Missouri and Rhode Island [TxDOT, 2000]. Congress made a major change to 
the program that requires all funds capitalized into the SIB and all future repayments of SIB assistance for all sources (including non-federal sources as well) to be federal funds. It changed the previous status of funds in the SIB after they were repaid from non-federal sources to become state funds [Clary, 2001].

This change may prevent some entities from seeking SIB assistance since they must now meet all federal requirements to qualify for assistance on a project. Meeting the federal requirements may significantly delay project schedules and increase overall project costs. The SIBs established under the NHS Act in other states continue to exist, but starting from 1998 federal funds cannot be used to capitalize them unless authorized by FHWA.

A SIB is similar to a lending institution and holds state and federal transportation money for distribution to eligible parties interested in making transportation improvements within the state. Much like a private bank, a SIB uses seed capitalization funds to get started and offers customers loans and credit enhancement products (Figure 4.48).

Capitalization

SIB Account

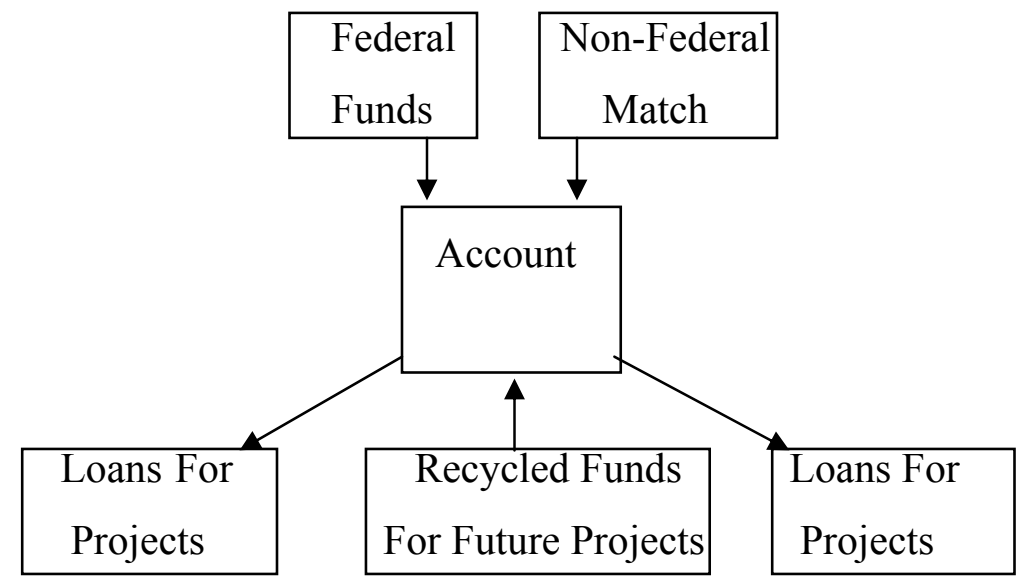

Figure 4.48 Basic Structure of a State Infrastructure Bank [FHWA, 1999c].

The NHS Act of 1995 required SIBs to have two separate accounts - a highway account and a transit account. The SIB authorization in TEA-21, however, eliminated the requirement for separate highway and transit accounts [FHWA, 1999c].

Each state may request federal funds to capitalize a SIB and deposit its matching contribution for the SIB. Funds from SIB accounts are lent to a project. When a borrower makes loan repayment, it is recycled to make loans to other projects. By preserving the 
corpus (body of the fund) of the SIB, a state can provide expanded financial assistance to projects in perpetuity.

\subsubsection{SIB Capitalization and Leveraging}

When establishing a SIB is considered, capitalization and leveraging are the foremost financial issues to be addressed. Capitalization is the process of depositing various funds as seed capital into the SIB to enable financial services [FHWA, 1997c].

A SIB capitalization begins with matching contributions of federal and nonfederal funds. Legislation permitted each of the states approved for the SIB program to contribute up to 10 percent of apportioned federal funding received in years 1996 and 1997 for most highway and transit programs. TEA-21 removed the 10 percent limit on the amount of federal-aid that could be used for capitalization. Subsequently, four states (California, Florida, Missouri, and Rhode Island) approved for the new SIB program, can use an unlimited amount of federal fund apportionment for a revolving loan fund [FHWA, 1999b].

The deposit of federal funds into a SIB occurs through advanced capitalization (ACAP), which is a procedure that permits each authorized state to notify FHWA when it has identified federal assistance that it may convert to a SIB capitalization source. It establishes a baseline from which to calculate the maximum amount of federal funding that may be deposited into a SIB during succeeding years [FHWA, 1997c]. The ACAP amount usually is deposited into a SIB over the nine-year period according to the governed outlay rate (Figure 4.49).

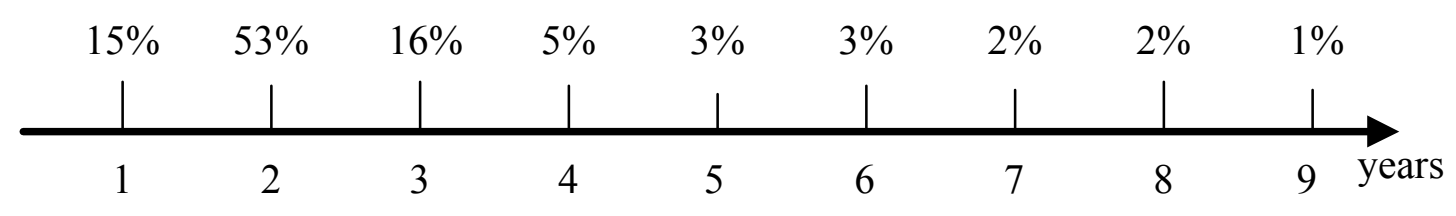

Figure 4.49 Outlay Rate for Federal-aid Highway Programs [FHWA, 1997c]. 
For the new SIB program under TEA-21, a five-year disbursement schedule was established. The outlay rate represents the expenditure assumptions used by the Office of Management and Budget when calculating the impact of obligations of federal-aid highway funds on actual annual federal expenditures. According to Figure 4., the largest amount of capitalization can be received in the first three years after a SIB is established. By September 30, 1999, $\$ 516.5$ million of federal funds had been deposited into the highway and transit accounts of the 39 approved SIBs [FHWA, 1999b]. States are required to contribute 25 percent of the federal contribution from non-federal sources. Other contributions beyond the required non-federal match are also accepted.

Leveraging can have a powerful effect on the amount of assistance that can be generated from the funds capitalized in a SIB. A bank is considered leveraged if its total

potential liabilities exceed its liquid assets [FHWA, 1997c]. Leverage increases the magnitude of assistance a SIB can offer beyond its cash-on-hand.

A SIB may be leveraged in two ways.

1) By issuing debt, e.g., bonds.

Bond issuance can be used to increase the amount of money that can be provided to potential project sponsors in the form of a loan or credit enhancement.

2) By guaranteeing liability for others' debts in an amount greater than the SIB's cash.

In this case leverage is derived from the fact that the guaranteed debt service is substantially greater than the SIB reserves.

\subsubsection{Types of SIB Financial Assistance}

The SIB program is intended to give state and local officials new flexibility in terms of the execution of transportation infrastructure projects. SIB may provide financial support to public and private sponsors of eligible surface transportation projects during all project stages. The spectrum of SIB financial assistance is shown in Table 4.14. 
Table 4.14 The Spectrum of SIB Assistance [FHWA, 1997c].

\begin{tabular}{|l|l|l|}
\hline \multicolumn{1}{|c|}{ Pre-construction } & \multicolumn{1}{|c|}{ Highway construction } & \multicolumn{1}{|c|}{ Transit Capital Acquisition } \\
\hline $\begin{array}{l}\text { - Planning and cost } \\
\text { estimation }\end{array}$ & - Project construction & - Transit project purchase \\
- Feasibility studies & - Additional bond issuance & $\begin{array}{l}\text { - Equipment and rolling } \\
\text { - Environmental and } \\
\text { stock acquisition }\end{array}$ \\
- Pronomic impact studies & & - Additional bond issuance \\
- Right-of-way acquisition & & \\
- Project engineering & & \\
- Project bond issuance & & \\
\hline
\end{tabular}

A SIB may assist project financing during any stage of the project by applying different tools. The types of financial assistance that may be provided by a SIB can be divided into two categories: loans and credit enhancement.

\section{Loans}

The most popular SIB assistance tool appears to be a loan. According to the FHWA description of a loan by SIB, it is a form of financial assistance made available by the SIB to a project sponsor with the provision that the loan principal will be repaid subject to terms and conditions agreed to at the time the loan is made. A loan can be provided during any stage of an eligible project.

Since the demand for SIB loans may be high due to the flexible terms and low interest rates, it is important to use SIB funds strategically to assist as many projects as possible. Therefore, a loan as a form of assistance could be used for projects at stages that are less likely to receive funds from any other source, i.e., the pre-construction phase where the project's feasibility and other studies have been completed and costs and revenues have been estimated.

As mentioned earlier, the interest rate on a loan and the term of loan repayment are flexible and can be structured to meet the needs of a specific project. According to the NHS Act of 1995 the repayments on a loan must commence no later than five years after the project has been completed. Repayments must be completed within 30 years after the 
project start date. In addition to the general guidelines, each state may establish its own rules regarding repayment and the cost of the loan, avoiding conflict with the federal ones. Table 4.15 shows examples of different conditions for loan issuance among several states. As shown in Table 4.15 conditions for loan issuance vary from state to state, but they all meet the general requirements.

Table 4.15 Loan Issuance Conditions in Different States [Varney, 2000].

\begin{tabular}{|l|l|l|}
\hline \multicolumn{1}{|c|}{ State } & \multicolumn{1}{|c|}{ Interest rate } & \multicolumn{1}{c|}{ Repayment conditions } \\
\hline Michigan & $\begin{array}{l}\text { 4\% in 1998, shall not } \\
\text { exceed market rate }\end{array}$ & $\begin{array}{l}\text { Maximum term 25 years, must begin within 2 } \\
\text { years after project completion }\end{array}$ \\
\hline Vermont & $\begin{array}{l}\text { At or below applicable } \\
\text { market rates }\end{array}$ & $\begin{array}{l}\text { Maximum term 30 years, must begin within 5 } \\
\text { years after project completion }\end{array}$ \\
\hline Maine & $\begin{array}{l}\text { Interest free loans to the } \\
\text { municipalities }\end{array}$ & Repayment term from 1 to 10 years \\
\hline Oregon & $\begin{array}{l}3.5-5.0 \text { percent range, } \\
\text { two loans at rate less } \\
\text { than 1 percent }\end{array}$ & Repayment term from 2 to 20 years \\
\hline Texas & $\begin{array}{l}\text { Depend on the term, } \\
\text { credit rating, priority of } \\
\text { project, market rate }\end{array}$ & $\begin{array}{l}\text { Maximum term 30 years, usually begin within 1 } \\
\text { year from disbursement date, may have } \\
\text { deferments up to 5 years }\end{array}$ \\
\hline
\end{tabular}

In most cases the states indicate some range within which the interest rate on a SIB loan may vary. Usually, it depends on the repayment terms, project characteristics, level of risk, and current market rate. Michigan DOT (MDOT) is the only state that showed a constant interest rate of four percent in 1998 for SIB loans.

The SIB established by the Maine DOT is unique in its operation because it provides interest-free loans. Its capitalization level is just over $\$ 3$ million, and it has partly funded 22 projects through August 2000, incurring loan obligations slightly more than $\$ 1.6$ million. Maine's SIB has been used to help fund projects on the state's major collector roads, which have been largely ignored over the last few years [Varney, 2000].

In most cases the repayment terms were set shorter than stated in the NHS Act, which benefits the sustainability of the SIB and a greater turnover of SIB funds. There is usually no penalty for early payoffs (if a payment is received earlier than a due date). 
Early repayment of SIB loans allows financial assistance to be provided to more projects and may reduce the interest cost to the borrower. Some states indicated that a project with a shorter amortization period would be more attractive for a loan. The primary benefit of providing loans is that the loan repayments are recycled to fund future projects in a state.

\section{Credit Enhancement}

A SIB can also offer different credit enhancement tools to support transportation projects that are funded primarily through other sources, which can increase confidence by the public investors, lower interest rates, and perhaps lower total project cost.

In general, credit enhancement is a third-party financial report that makes a loan, bond, or other financial instrument more creditworthy and provides access to more satisfactory borrowing conditions [FHWA, 1999c]. A SIB can offer a credit enhancement by guaranteeing the borrower's repayment of principal and/or interest to the investor. As a result, a project owner or a sponsor may gain access to external financing that otherwise would not be possible, or may not be able to obtain at such an attractive rate of interest.

From a state perspective, credit enhancement through a SIB is more advantageous than loan issuance because fewer resources are tied up and actually distributed, and thus, more projects can be assisted. Several types of credit enhancement can be available through a SIB, such as lines of credit, debt service guarantees (letters of credit and bond insurance), and debt service reserves.

A line of credit is a form of loan to be used only if there is a shortfall in net revenues for debt service coverage. If the borrower does not have enough cash to cover the interest payments, the SIB can lend the money.

Guarantees to meet debt service requirements can be offered by a SIB in the form of a letter of credit or as bond insurance. The difference between a line of credit and a guarantee is that the commitment for debt repayment is tied directly to the guarantee lender rather than the borrower.

Bond insurance enhances the credit rating on bonds. When a bond is insured, it is given an AAA rating even if it had a lower rating before issuance [Faerber, 2000], which in turn can save interest cost to the borrower. 
When a highway project is financed by issuing bonds, a debt service reserve fund must be set aside for future contingencies that could affect the repayment of debt service on revenue bonds. This fund is drawn upon in the event that the project is unable to make debt service payments to bondholders [FHWA, 1999b].

SIB assistance can be used to provide a debt service reserve fund for individual projects. It would lend a project sponsor the funds needed to establish the reserve fund. A SIB can offer flexible repayment terms and lower interest rates and a project sponsor therefore may find it more attractive to acquire the debt service fund from a SIB.

\subsubsection{SIB in Indiana}

Many states have participated in the SIB program at various stages, and each has differed in its approach. Some SIB states have not pursued the program beyond receiving federal "seed" funds. Some SIB states have expanded to more active and mature programs with portfolios of loans. The Indiana SIB is in the development stage.

INDOT established its SIB in 1999. Federal and state funds were used for initial capitalization of the bank, and although the Indiana SIB was established after the changes in the SIB program under TEA-21, FHWA authorized special federal funds of slightly more than $\$ 1$ million to be capitalized in the bank. In addition, regular federal authorization funds of $\$ 3.39$ million were capitalized. The state provided its match with a 1:1 ratio to federal funds.

INDOT has specified its SIB assistance to be available for local projects only. As of early 2002, three projects have been authorized, and two of them have actually received the money, a total of $\$ 1$ million. The remaining capitalized amount has been invested and is accumulating interest. Indiana's SIB assistance is provided in the form of a loan for chosen projects at an interest rate of $3 \%$, which is below the market rate and similar to ones used by SIBs in other states (see Table 4.15).

The maximum term for a loan has been set at 20 years after completion of the project. No repayments are necessary until the project is completed and open to traffic. Revenue sources to repay the loan cannot include federal funds. The owners of the authorized projects use the revenues from TIF districts for loan repayment. 
There are no written guidelines for the Indiana SIB available at this time, which may restrict the use of this innovative financing technique due to the lack of information and an ill-defined scope of work. Documentation explaining the SIB program would assist applicants for financial assistance and would also clearly define the purpose of this financing technique to the public and to potential users of the SIB. As more projects are assisted by the Indiana SIB, the bank will have greater turnover, resulting in benefit to the public through more completed projects.

The Indiana SIB provides a great opportunity to realize completion of more local transportation projects. Making the Indiana SIB more accessible to any local public or private entity authorized by law to construct, maintain, or finance a transportation project, INDOT could:

- expand the availability of innovative funding to local transportation projects and thus reduce the state costs in these projects;

- attract new public and private investment in transportation infrastructure;

- reduce project costs by providing a low-cost flexible financing technique; and

- improve the efficiency of county and state transportation systems by accelerating the execution of projects.

SIB assistance could be used in public-private partnerships as well. For example, build-operate-transfer projects are constructed and operated by private sector for a given period of time and then transferred to public ownership. The SIB as a public organization could provide financial assistance to such partnership agreements.

The authorizing legislation limits the annual disbursement of SIB funds, thus reducing the capacity of SIBs to provide large amounts of credit assistance in the near term. Consequently, SIBs are best suited to assist portfolios of smaller, relatively homogenous, shorter-term projects that are regional or local in scope, thus, assisting more projects with limited funds and achieving greater turnover.

\subsection{Comparison Between Available Innovative Financing Techniques}

Four major innovative financing techniques associated with the use of federal funds have been analyzed and evaluated in this study. Each of them can provide a 
significant amount of additional funding in order to accelerate the execution of a project. The techniques differ from one another as to the tools, limitations, applicability, and other characteristics. A summary of major characteristics of financing techniques evaluated in the study is provided in Table 4.16 .

The GARVEE program seems to be the most versatile as it is applicable to different types of projects. It does not have any specific project requirements, nor are there any limitations on the bonding capacity that may be used for a project. SIB assistance does not require special conditions for a project either, but it is limited in its own capital. TIFIA is the innovative financing technique that has more constraints than the others as it is available for a limited number of projects and the amount of available assistance is restricted.

The GARVEE program does not require the state to seek non-federal sources of revenue, as federal-aid reimbursement can be used for repayment of debt. For TIFIA or SIB assistance, non-federal sources of future revenues need to be determined in advance. The TE-045 program cannot be compared with the other three innovative financing techniques, as it does not offer actual funding, rather it only provides opportunities for innovative financing tools to be used.

There are certain types of projects for which the evaluated techniques are more suitable than others. Thus, the GARVEE program is more applicable for large, long-term projects, e.g., the U.S. 31 Corridor Improvement Project. The TIFIA program is meant to assist major transportation investment projects of regional or national importance, e.g., the I-69 project. SIB assistance is more favorable to small, short-term projects due to the way the Bank is capitalized and its operation. 
Table 4.16 A Comparison of Innovative Financing Techniques.

\begin{tabular}{|l|l|l|l|l|}
\hline & \multicolumn{1}{|c|}{ GARVEE } & \multicolumn{1}{|c|}{ TIFIA } & \multicolumn{1}{c|}{ SIB } & \multicolumn{1}{c|}{$\begin{array}{c}\text { TE-045 } \\
\text { Program }\end{array}$} \\
\hline Description & $\begin{array}{l}\text { Bonds, Section } \\
129 \text { loans }\end{array}$ & $\begin{array}{l}\text { Loans, loan guarantees, } \\
\text { lines of credit }\end{array}$ & $\begin{array}{l}\text { Loans, credit } \\
\text { assistance }\end{array}$ & $\begin{array}{l}\text { New } \\
\text { investment } \\
\text { tools and cash } \\
\text { flow tools }\end{array}$ \\
\hline Authorization & Federal, state & Federal, state & Federal, state & Federal \\
\hline $\begin{array}{l}\text { Limitations of } \\
\text { Amount }\end{array}$ & No specific limit & $\begin{array}{l}\text { Credit assistance may } \\
\text { not exceed 33\% of total } \\
\text { project costs. Minimum } \\
\text { project size } \$ 100 \\
\text { million. }\end{array}$ & $\begin{array}{l}\text { No limits for a } \\
\text { project. Limited } \\
\text { capital of SIB. }\end{array}$ & N/A \\
\hline $\begin{array}{l}\text { Method of } \\
\text { Payback }\end{array}$ & $\begin{array}{l}\text { Federal-aid } \\
\text { reimbursement }\end{array}$ & $\begin{array}{l}\text { Non-Federal sources } \\
\text { (tolls, state/local taxes } \\
\text { and others) }\end{array}$ & $\begin{array}{l}\text { Non-Federal } \\
\text { sources (tolls, } \\
\text { state/local taxes } \\
\text { and others })\end{array}$ & N/A \\
\hline Applicability & $\begin{array}{l}\text { Big, long term } \\
\text { projects }\end{array}$ & $\begin{array}{l}\text { Major transportation } \\
\text { investment projects of } \\
\text { regional or national } \\
\text { importance. }\end{array}$ & $\begin{array}{l}\text { Small, short-term } \\
\text { projects }\end{array}$ & $\begin{array}{l}\text { Different types } \\
\text { of projects }\end{array}$ \\
\hline $\begin{array}{l}\text { Legislation } \\
\text { Federal }\end{array}$ & Federal, state & Federal, state & Federal \\
\hline
\end{tabular}

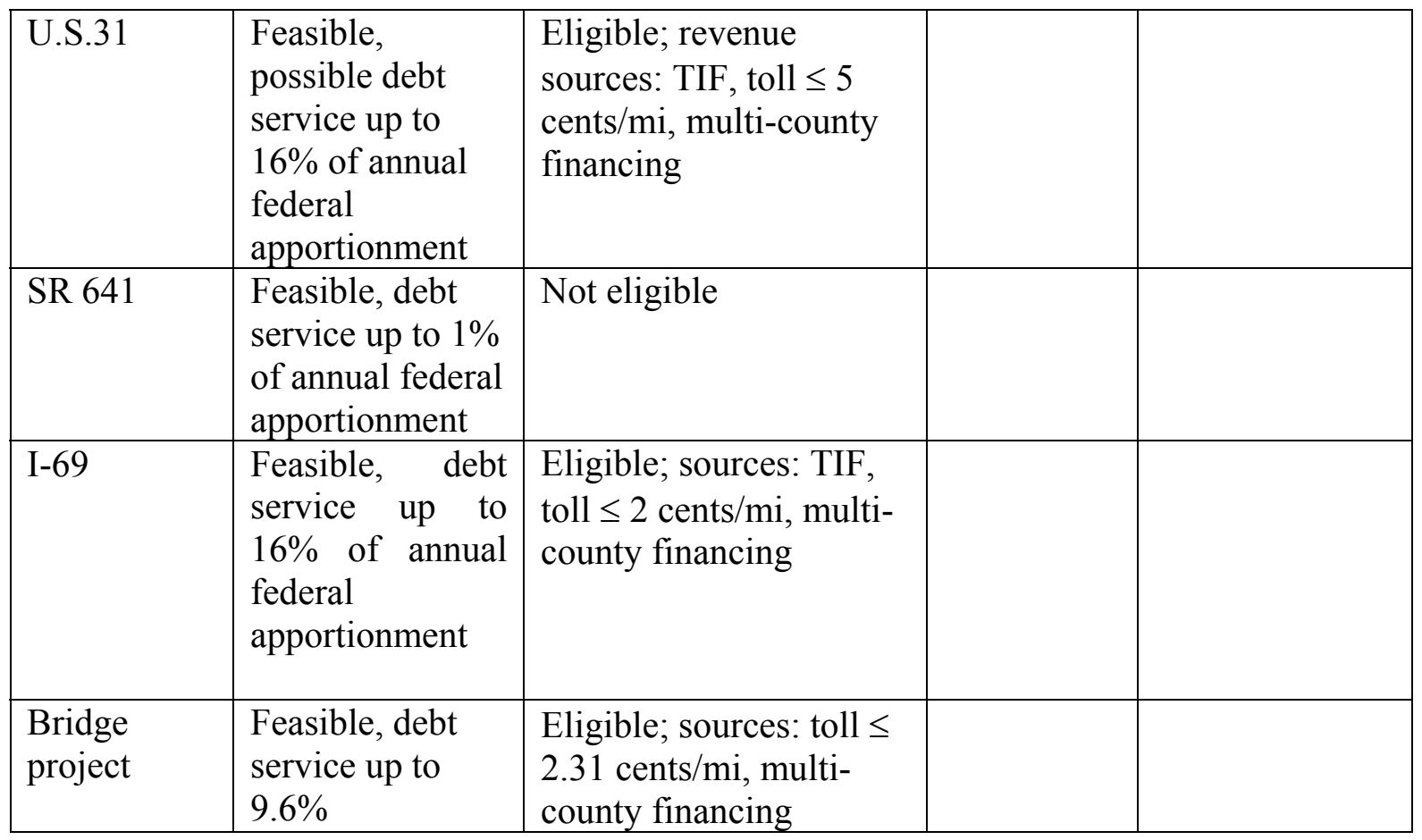




\section{CHAPTER 5. CONCLUSIONS AND RECOMMENDATIONS}

The Indiana highway system is mainly supported by federal and state fuel taxes and other related fees. It is not easy to change practices that have served well for many years, but the traditional "pay-as-you-go" financing approach is increasingly unable to satisfy the accelerating needs for improvement in the state highway system. There are several innovative financing tools provided by federal government that the states are allowed to use in order to expand the use of existing federal funds. A summary of the study's findings is provided in the first section of this chapter, which is followed by a discussion of further research and recommendations for implementation of study results in Indiana.

\subsection{Summary of Findings}

This study was intended to evaluate innovative financing techniques associated with the use of federal funds and their applicability for Indiana. The alternative techniques discussed here are not the only ones available, but they do represent the options most likely to yield a significant increase in funding and accelerating the execution of projects in Indiana. Most of the innovative financing techniques will not generate the total needed amount for a project to be completed, however, using these innovative financing tools can significantly supplement the available funds and thereby accelerate realization of a project.

TE-045 program provides a wide spectrum of innovative financing techniques associated with federal funds. TE-045 does not provide financial assistance; rather it fosters the identification and implementation of new, flexible strategies to overcome the fiscal, institutional, and administrative obstacles in financing highway projects.

Innovative financing techniques can be adapted to leverage the use of available federal and state funding, and different techniques can be chosen according to project 
size, term, geographical location, and other characteristics. Some techniques, e.g., GARVEE bonds, are applicable to most project types, while others, e.g., TIFIA, are restricted in their use.

A large share of the project cost could be financed through GARVEE bonds. GARVEE financing is appropriate when the additional public benefits resulting from early project completion exceed the financing costs. Economic analysis concludes that the debt service for such a bond issuance could likely be met through existing state sources for debt service payments in Indiana (SHRCIF and Crossroads 2000 Fund).

The TIFIA program is limited in its use, but it can be a helpful tool to fund projects possessing their own non-federal repayment streams. For implementation in Indiana, the feasibility of using such sources as tax increment financing or tolls can be considered to cover costs incurred in using TIFIA assistance.

Small, short-term projects could be financed through loans provided by a SIB. Since Indiana SIB capital is very limited, this technique is more applicable to projects at the local level.

Most of the innovative financing techniques discussed in the study involve borrowing money. It is preferable to use GARVEE or TIFIA programs rather than borrow money from a regular lending institution, as interest rates under these programs tend to be lower and repayment conditions more flexible. The interest rate, discount rate, and term of borrowing are the critical factors that need to be carefully considered to evaluate the impact of innovative financing techniques on economic viability of a project.

Innovative financing does not create additional sources of revenue but provides flexibility in the use of available resources so that projects can be started earlier, whereby an increased level of improvement activities can be accomplished to benefit the highway users in Indiana.

\subsection{Recommendations for Further Investigation and Implementation}

The present study examined the available innovative financing techniques that could be applicable in Indiana, thereby extending the use of existing federal and state highway funds. Some of the factors related to the use of certain techniques were 
identified and their influence on the economic and financial parameters of a project was analyzed. The following recommendations are suggested for possible further investigation and implementation.

a The financial market conditions should be carefully examined before applying financing techniques that involve borrowing. Particular attention should be paid to such factors as interest rate, discount rate, and consistent flow of revenues.

- It is recommended that documentation defining the objectives of the Indiana SIB be prepared and should include the scope of work and eligibility requirements for financial assistance. Such documentation would serve as a basis to make Indiana SIB assistance more accessible to public and private entities for transportation project financing.

- Comparison between the impacts of different financing techniques can be made in greater detail than what was possible in the present study. For such a comparison, it will be necessary to have detailed information on specific projects, including the economic analysis data specific to the requirements of various financing techniques. Such an analysis can suggest possible optimal financial formulas based on economic and financial measures as performance indicators.

a The findings of this study are expected to be implemented by the Budget and Fiscal Management Division of INDOT. The study provides a framework for the evaluation of the use of innovative financing techniques described in this report. With detailed project specific data, project-by-project analysis can be done to find the optimal solution for individual project financing. 


\section{LIST OF REFERENCES}

Amt, W. (2000) Tax Increment Financing Boosts Local Tax Base. Economic Development Digest, NADO Vol.11, No.10. Available at: http://www.nado.org/pubs/sept6.html

Bernardin, Lochmueller \& Associates, Inc. [BLA] (2001) The I-69 Evansville-toIndianapolis Study. Alternatives Analysis Report. Prepared for INDOT, West Lafayette, IN.

Brown, D. (2001) More States Pursue GARVEEs. Innovative Finance Quarterly Vol. 7, No.1, FHWA, Washington D.C.

Cambridge Systematics, Inc. [CS] (1989) The Economic Impacts of Highway Improvements in Southwest Indiana. Draft Report. Prepared for INDOT in cooperation with the U.S.Department of Transportation Federal Highway Administration.

Cambridge Systematics, Inc. and Bernardin, Lochmueller \& Associates, Inc [CS \& BLA] (1998) Economic Impacts of U.S.31 Corridor Improvements. Final Report. Prepared for INDOT, Cambridge, Massachusetts.

Clary, L. (2001) Evaluation of the State Infrastructure Bank. Florida DOT. Available at : www.dot.state.fl.us/financialplanning

Dornan, D.L. (2000) Asset Management and Innovative Finance. Proceedings of Second National Conference on Transportation Finance, Transportation Research Board, Scottsdale, Arizona.

Faerber, E. (2000) All About Bonds and Bond Mutual Funds: the Easy Way to Get Started. $2^{\text {nd }}$ Edition, McGraw-Hill.

Federal Highway Administration, Indiana Department of Transportation \& Kentucky Transportation Cabinet [FHWA, INDOT \& KYTC]. (2001) Louisville-Southern Indiana Ohio River Bridges Project Draft Environmental Impact Statement

Federal Register (1996), Environmental Impact Statement; Vigo County, Indiana. (Vol. 61, Number 224).

FHWA (2001) Transportation Infrastructure Finance and Innovation Act. The TIFIA Times, Issue No.1, FHWA, Washington D.C.

FHWA (2000) Price Trends for Federal-Aid Highway Construction, Fourth Quarter 2000. Publication number FHWA-IF-01-008, Washington D.C.

FHWA (1999a) Price Trends for Federal-Aid Highway Construction, Fourth Quarter 1999. Publication number FHWA-IF-00-021, Washington D.C.

FHWA (1999b) An Evaluation of the U.S. Department of Transportation State Infrastructure Bank Pilot Program - SIB Report to Congress, Washington D.C.

FHWA (1999c) Financing Federal-Aid Highways. Publication No.FHWA-PL-99-015, Washington D.C.

FHWA (1999d) 1999 Status of the Nation's Surface Transportation: Conditions and Performance Report. Washington D.C. 
FHWA (1998) Price Trends for Federal-Aid Highway Construction, Fourth Quarter 1998. Publication number FHWA-IF-99-001, Washington D.C.

FHWA (1997a) Innovative Finance Home Page. Available at: http://www.fhwa.dot.gov/innovativefinance

FHWA (1997b) Price Trends for Federal-Aid Highway Construction, Fourth Quarter 1997. Publication number FHWA-PD-98-009, Washington D.C.

FHWA (1997c) State Infrastructure Bank Primer. Available at: www.fhwa.dot.gov/innovativefinance

Giglio, J.M. (2000) Strategic Alternatives for Financing the Highway System. Proceedings of Second National Conference on Transportation Finance, Transportation Research Board, Scottsdale, Arizona.

Grote, B. (2000) Transportation Secretary Announces TIFIA Project Selections. Innovative Finance Quarterly, Vol.6, No.3, FHWA, Washington D.C.

Hazeltine, Michael D. (2002), INDOT, Communication with A. Vincent Genetti, 28 February 2002.

Henry, P. (2000) Recent Developments to TIFIA Program. Draw Mixed Reaction. Torys on Public Finance. Available at: www.torys.com

Indiana Legislative Services Agency [ILSA] (1999) Indiana Handbook of Taxes, Revenues, and Appropriations. Indianapolis, IN.

Indiana Legislative Services Agency [ILSA] (2000) Indiana Handbook of Taxes, Revenues, and Appropriations. Indianapolis, IN.

INDOT (1995) Engineer's Report New Road Construction SR 641 Terre Haute Bypass. Indianapolis, IN.

INDOT (2001a) 2001 Annual Report. Indianapolis, IN.

INDOT (2001b) INDOT 2000-2025 Long Range Plan. Indianapolis, IN.

INDOT (1998) INDOT Road Inventory. Indianapolis, IN.

INDOT (2002a) Ohio River Bridges Project Overview. Available at: http://www.kyinbridges.com/overviewhistory.html

INDOT (2002b) Average Annual Daily Traffic By County. Available at: http://www.ai.org/dot/div/traffic/count/index.html

Inman, M. (2000) GARVEE Issues Approach \$1 Billion. Innovative Finance Quarterly, Vol.6, No.3, FHWA, Washington D.C.

Indiana Transportation Finance Authority [ITFA] (2000) Highway Revenue Bonds, Series 2000. ITFA, Indianapolis, IN.

Jones, Ph. (2001) SIB Activity Tops \$2.4 Billion. Innovative Finance Quarterly Vol. 7, No.1, FHWA, Washington D.C.

Long, R. (1999) Grant Anticipation Revenue Vehicles: An Option to Finance Transportation Projects. Legislative Analysts Office, California Update. Available at: www.lao.ca.gov 
Marx, P. (2000) The State of the States on GARVEEs. Innovative Finance Quarterly, Vol.6, No.1, FHWA, Washington D.C.

Parsons Transportation Group (2000) US 31 Improvement Project Purpose and Need Statement (Hamiliton County). Prepared for INDOT \& FHWA.

Ross, S.A,Westerfield R.W. and Jaffe J. (1999) Corporate Finance. $5^{\text {th }}$ Edition, Irwin/McGraw-Hill.

Roskin, M. (1997) TE-045 Projects. Overview. Conference proceedings 15, Transportation Finance for the $21^{\text {st }}$ Century, Dallas, Texas.

Seltzer, D. (2000) Recent Developments in Federal Project Finance. Public Roads, Vol.63, No.4, FHWA, Washington D.C.

Streeter, W., and George C. (2001) TIFIA Springs Into Action. FITCH Inc., Public Finance. Available at: http://www.fitchibca.com/.

Trujillo, C. (2000) New Mexico Pioneers Another New GARVEE Financing. Innovative Finance Quarterly, Vol.7, No.1. FHWA, Washington D.C.

TxDOT (2000) State Infrastructure Bank Applicant Handbook. $2^{\text {nd }}$ Edition. Austin, TX.

Van Horne, J.C. (2001) Financial Market Rates and Flows. Prentice-Hall, Inc., Upper Saddle River, NJ.

Varney, T. (2000) SIBs Demonstrate Their Effectiveness in Funding Transportation Infrastructure. Innovative Finance Quarterly, Vol.6, No.2., FHWA, Washington D.C.

White, D. (2000) South Carolina: Considering 27 Years of Projects into Seven Years. Innovative Finance Quarterly, Vol.6, No.3., FHWA, Washington D.C. 
APPENDIX 


\section{Appendix A. Estimated VMT on U.S. 31}

\section{(Indianapolis to South Bend)}

\begin{tabular}{|c|c|c|c|c|c|c|c|}
\hline \multirow{2}{*}{$\begin{array}{c}\text { ROAD } \\
\text { NUMBER }\end{array}$} & \multirow{2}{*}{ COUNTY } & \multirow{2}{*}{$\begin{array}{l}\text { CODE } \\
\text { NO. }\end{array}$} & \multirow{2}{*}{ AADT } & \multicolumn{2}{|c|}{ SECTION LINK TERMINI } & \multirow{2}{*}{$\begin{array}{l}\text { ESTIMATED } \\
\text { DISTANCE } \\
\text { (MILES) }\end{array}$} & \multirow{2}{*}{$\begin{array}{l}\text { ESTIMATED AVERAGE } \\
\text { ANNUAL VEHICLE MILES } \\
\text { TRAVELED }\end{array}$} \\
\hline & & & & FROM & TO & & \\
\hline & \multirow{7}{*}{$\begin{array}{c}\text { Fulton } \\
1999\end{array}$} & $1 \mathrm{~A}$ & 9,210 & Miami County Line & IR-1 [Old US-31] & \multirow{3}{*}{6.0} & \multirow{3}{*}{$22,615,400$} \\
\hline & & $2 \mathrm{~A}$ & 10,220 & IR-1 [Old US-31] & SR-25 & & \\
\hline & & $3 \mathrm{~A}$ & 11,550 & SR-25 & SR-14 & & \\
\hline & & $4 \mathrm{~A}$ & 11,080 & SR-14 & IR-50 [100 North] & \multirow{4}{*}{8.0} & \multirow{4}{*}{$28,411,600$} \\
\hline & & $5 \mathrm{~A}$ & 8,320 & IR-50 [100 North] & IR-62 [250 North] & & \\
\hline & & $6 \mathrm{~A}$ & 8,210 & IR-62 [250 North] & IR-76 [550 North] & & \\
\hline & & $7 \mathrm{~A}$ & 11,310 & IR-76 [550 North] & Marshall County Line & & \\
\hline & \multirow{12}{*}{$\begin{array}{c}\text { Hamilton } \\
1998\end{array}$} & 1B & 43,270 & 1-465 Interchange & 116th St. [Carmel] & \multirow{5}{*}{6.4} & \\
\hline & & $2 \mathrm{~B}$ & 32,290 & 116th St. [Carmel] & 126th St. [Carmel] & & \\
\hline & & $3 \mathrm{~B}$ & 33,390 & 126th St. [Carmel] & IR-18 [131st St.] & & $82,231,872$ \\
\hline & & $4 \mathrm{~B}$ & 28,720 & IR-18 [131st St.] & Walter Rd. [Rangeline Rd.] & & \\
\hline & & $5 \mathrm{~B}$ & 38,340 & Walter Rd. [Rangeline Rd.] & SR-431 & & \\
\hline & & $6 \mathrm{~B}$ & 56,340 & SR-431 & IR-34 [Gray Rd. - 146th St.] & & \\
\hline & & $7 \mathrm{~B}$ & 39,350 & IR-34 [Gray Rd. - 146th St.] & 169th St. [Westfield] & 3.2 & $53,070,027$ \\
\hline & & $8 \mathrm{~B}$ & 40,620 & 169th St. [Westfield] & SR-32 & & \\
\hline & & 9B & 31,620 & SR-32 & IR-904 [196th St.] & 2.0 & $23,082,600$ \\
\hline & & 1AA & 28,260 & IR-904 [196th St.] & SR-38 & 2.0 & $20,629,800$ \\
\hline & & 2AA & 27,220 & SR-38 & IR-78 [236th St.] & & \\
\hline & & $3 A A$ & 25,360 & IR-78 [236th St.] & Tipton County Line & 10.8 & $103,635,180$ \\
\hline & & $1 \mathrm{~A}$ & 29,230 & Tipton County Line & SR-26 & & \\
\hline & & $2 \mathrm{~A}$ & 31,400 & SR-26 & IR-6 [Center Rd.] & 1.2 & $13,277,970$ \\
\hline & & $3 \mathrm{~A}$ & 38,340 & IR-6 [Center Rd.] & Southway Blvd. & & \\
\hline & & $4 \mathrm{~A}$ & 45,100 & Southway Blvd. & Lincoln Rd. [Kokomo] & 3.2 & $51,282,987$ \\
\hline & Howard & $5 \mathrm{~A}$ & 48,280 & Lincoln Rd. [Kokomo] & US 35 [Jct. South]/SR 22 [Jct. East] & & \\
\hline & 1997 & $6 \mathrm{~A}$ & 47,630 & US 35 [Jct. South]/SR 22 [Jct. East] & Sycamore St. [Kokomo] & & \\
\hline & & $7 \mathrm{~A}$ & 39,810 & Sycamore St. [Kokomo] & North St. [Kokomo] & & \\
\hline & & $8 \mathrm{~A}$ & 32,170 & North St. [Kokomo] & Ohio St. [Kokomo] & 4.0 & $53,235,250$ \\
\hline & & $9 \mathrm{~A}$ & 26,240 & Ohio St. [Kokomo] & US 35 [Jct. North] & & \\
\hline & & $10 \mathrm{~A}$ & 19,760 & US 35 [Jct. North] & Miami County Line & 1.6 & $11,539,840$ \\
\hline US 31 & & $1 \mathrm{C}$ & 13,010 & Fulton County Line & SR-10 & 4.7 & $22,318,655$ \\
\hline & & $2 \mathrm{C}$ & 14,110 & SR-10 & Old US-31 / IR-38 [W. 13th Rd.] & & \\
\hline & & $3 \mathrm{C}$ & 13,350 & Old US-31 / IR-38 [W. 13th Rd.] & IR-373 & 8.0 & $38,962,533$ \\
\hline & Marshall & $4 \mathrm{C}$ & 12,570 & IR-373 & US-30 & & \\
\hline & 1999 & $5 \mathrm{C}$ & 11,610 & US-30 & $\begin{array}{l}\text { IR-45 [6th Run West] } \\
\end{array}$ & & \\
\hline & & $6 \mathrm{C}$ & 15,780 & \begin{tabular}{|l} 
IR-45 [6th Run West] \\
\end{tabular} & \begin{tabular}{|l|l|l|l|} 
IR-375 \\
\end{tabular} & 6.4 & $39,657,493$ \\
\hline & & $7 \mathrm{C}$ & 23,540 & 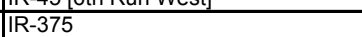 & US-6 [Lapaz] & & \\
\hline & & $8 \mathrm{C}$ & 21,350 & US-6 [Lapaz] & St. Joseph County Line & 2.0 & $15,585,500$ \\
\hline & & 1B & 19,760 & Howard County Line & SR-18 & 2.0 & $14,424,800$ \\
\hline & & $2 \mathrm{~B}$ & 18,930 & SR-18 & IR-26 [800 South] & & \\
\hline & & $3 B$ & 23,440 & IR-26 [800 South] & SR-218 [Jct. East] & 5.2 & $40,209,130$ \\
\hline & & 4B & 23,890 & SR-218 [Jct. East] & SR-218 [Jct. West] & & \\
\hline & & $5 \mathrm{~B}$ & 17,610 & SR-218 [Jct. West] & IR-99 & 5.2 & $33,891,953$ \\
\hline & Miami & $6 \mathrm{~B}$ & 12,070 & IR-99 & US 24 [Jct. West] & & \\
\hline & 1997 & & & & US-31 follows over US-24] & & \\
\hline & & $7 \mathrm{~B}$ & 14,930 & US 24 [Jct. East] & IR-188 [100 North] & & \\
\hline & & $8 \mathrm{~B}$ & 10,610 & IR-188 [100 North] & IR-52 [200 North] & 6.4 & $27,876,267$ \\
\hline & & $9 \mathrm{~B}$ & 10,260 & IR-52 [200 North] & SR-16 & & \\
\hline & & $1 \mathrm{C}$ & 9,460 & SR-16 & IR-76 [800 North] & 2.1 & $7,251,090$ \\
\hline & & $2 \mathrm{C}$ & 9,130 & IR-76 [800 North] & Fulton County Line & 7.2 & $23,993,640$ \\
\hline & & $\overline{1 F}$ & 20,050 & Marshall County Line & Lake Trail [Lakeville] & & \\
\hline & & $2 \mathrm{~F}$ & 23,510 & Lake Trail [Lakeville] & Jefferson St. [Lakeville] & 4.8 & $40,331,040$ \\
\hline & St. Joseph & $3 \mathrm{~F}$ & 25,500 & Jefferson St. [Lakeville] & SR-431 & & \\
\hline & 1996 & $4 \mathrm{~F}$ & 21,930 & SR-431 & IR-26 [Osborne Rd.] & & \\
\hline & & $5 \mathrm{~F}$ & 22,710 & IR-26 [Osborne Rd.] & IR-46 [Roosevelt Rd.] & 6.0 & $52,370,200$ \\
\hline & & $6 \mathrm{~F}$ & 27,100 & IR-46 [Roosevelt Rd.] & US-20 & & \\
\hline & & $1 \mathrm{~A}$ & 24,780 & Hamilton County Line & SR-28 & 4.0 & $36,178,800$ \\
\hline & Tipton & $2 \mathrm{~A}$ & 27,330 & SR-28 & IR-28 [200 North] & & \\
\hline & 1998 & $3 \mathrm{~A}$ & 29,990 & IR-28 [200 North] & Howard County Line & 9.2 & $96,240,280$ \\
\hline TOTAL & & & & & & 121.6 & $952,303,907$ \\
\hline & STIIA & $\overrightarrow{\mathrm{AV}}$ & GE AN & INUAL VEHICLE MILES TRAVELED & 365*ESTIMATED DISTANCE (MILE & 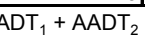 & $\ln$ \\
\hline & & & & Data extracted from information a & //www.ai.org/dot/div/traffic/co & & \\
\hline
\end{tabular}


Appendix B. State Infrastructure Bank Loan Agreements by State

(till March, 2001)

\begin{tabular}{|l|c|r|r|}
\hline State & $\begin{array}{c}\text { Number of } \\
\text { Agreements }\end{array}$ & $\begin{array}{c}\text { Loan Agreement } \\
\text { Amount } \mathbf{( \$ )}\end{array}$ & \multicolumn{1}{c|}{ Disbursements $\mathbf{\$}$ ) } \\
\hline Alaska & 1 & 2,737 & 2,737 \\
\hline Arizona & 14 & $205,976,000$ & $147,778,000$ \\
\hline Arkansas & 1 & 31,000 & 31,000 \\
\hline Colorado & 2 & 400,000 & 400,000 \\
\hline Delaware & 1 & $6,000,000$ & $6,000,000$ \\
\hline Florida & 15 & $219,184,000$ & $30,542,000$ \\
\hline Indiana & 1 & $3,000,000$ & 0 \\
\hline Iowa & 1 & 739,000 & 739,000 \\
\hline Maine & 22 & $1,768,000$ & 759,000 \\
\hline Michigan & 23 & $17,034,000$ & $13,033,000$ \\
\hline Minnesota & 3 & $36,560,000$ & $16,966,000$ \\
\hline Missouri & 8 & $56,008,000$ & $41,770,000$ \\
\hline Nebraska & 1 & $1,500,000$ & 0 \\
\hline New Mexico & 1 & 541,000 & 541,000 \\
\hline New York & 2 & $12,000,000$ & $12,000,000$ \\
\hline North Carolina & 1 & $1,575,000$ & $1,575,000$ \\
\hline North Dakota & 2 & $3,565,000$ & $1,565,000$ \\
\hline Ohio & 35 & $146,624,000$ & $102,550,000$ \\
\hline Oregon & 8 & $11,181,000$ & $11,181,000$ \\
\hline Pennsylvania & 15 & $14,600,000$ & $14,600,000$ \\
\hline Puerto Rico & 1 & $15,000,000$ & $15,000,000$ \\
\hline Rhode Island & 1 & $1,311,000$ & $1,311,000$ \\
\hline South Caroline & 5 & $1,502,289,000$ & $510,428,000$ \\
\hline South Dakota & 1 & $11,740,000$ & $11,740,000$ \\
\hline Tennessee & 1 & $1,875,000$ & $1,875,000$ \\
\hline Texas & 25 & $75,581,000$ & $65,736,000$ \\
\hline Utah & 1 & $2,888,000$ & $2,888,000$ \\
\hline Vermont & 3 & $1,030,000$ & 0 \\
\hline Virginia & 1 & $18,000,000$ & $18,000,000$ \\
\hline Washington & 1 & 700,000 & 0 \\
\hline Wisconsin & 2 & $1,188,000$ & $1,188,000$ \\
\hline Wyoming & 5 & $49,090,000$ & $32,614,000$ \\
\hline TOTAL & 204 & $2,421,715,000$ & $1,065,547,000$ \\
\hline
\end{tabular}

